\title{
ESSAY
}

\section{RISKY ARGUMENTS IN SOCIAL-JUSTICE LITIGATION: THE CASE OF SEX DISCRIMINATION AND MARRIAGE EQUALITY}

\author{
Suzanne B. Goldberg*
}

This Essay takes up the puzzle of the risky argument or, more precisely, the puzzle of why certain arguments do not get much traction in advocacy and adjudication even when some judges find them to be utterly convincing. Through a close examination of the sexdiscrimination argument's evanescence in contemporary marriage litigation, this Essay draws lessons about how and why arguments become risky in social-justice cases and whether they should be made nonetheless. The marriage context is particularly fruitful because some judges, advocates, and scholars find it "obviously correct" that laws excluding same-sex couples from marriage discriminate facially based on sex or impose sex stereotypes. Yet advocates have tended to minimize these arguments and most judges either sidestep or go out of their way to reject them.

Certain kinds of arguments, including the sex-discrimination argument in marriage cases, turn out to pose greater risks than others because they ask decisionmakers to confront long-settled social hierarchies and norms, such as those associated with gender roles. As a result, they risk inciting Burkean anxieties about the dangers of nonincremental change. Arguments that ask less of decisionmakers, such as those about animus associated with a particular enactment-or that have a more limited reach, such as heightened scrutiny for sexual orientation at a time when few explicitly antigay laws remain-are less likely to provoke that discomfort. Moreover, a win on these narrower arguments can also erode stereotypes and norms underlying a challenged law or social policy. In marriage cases, for example, a pro-equality ruling helps call longstanding marital gender roles into question even if the court's

* Herbert and Doris Wechsler Clinical Professor of Law, Columbia Law School. My thanks for helpful comments and discussion to Jessica Bulman-Pozen, Mary Anne Case, Ariela Dubler, Elizabeth Emens, William Eskridge, Julie Goldscheid, Kent Greenawalt, Bernard Harcourt, Lou Kelley, Andrew Koppelman, Gillian Metzger, Henry Monaghan, Jeff Powell, Dave Pozen, Carol Sanger, Jane Schacter, and Peter Strauss, and to participants in the Stanford Law School Symposium on Marriage Equality, the University of Minnesota Civil Rights \& Civil Justice: 50 Years Later symposium, and the Columbia Law School faculty workshop. For excellent research assistance, thanks to Catherine Djang, Kevin Hu, Genia Gokhmark, Logan Gowdey, June Morgan Hu, Julia Maddera, and the editors of the Columbia Law Review. 
decision never mentions sex discrimination. Still, risky arguments add value within litigation by powerfully calling attention to deep problems that underlie a challenged law. Through close study of these costs and benefits, the risky-argument frame advanced here aims to illuminate the complex dynamics of argumentation in the litigation and adjudication of social-justice cases.

INTRODUCTION

I. A PRIMER ON THE SEX-DiscriminATION ARgUMENT AND OTHER LEGAL THEORIES IN MARRIAGE CASES .............................................2099

A. The Formal-Equality Argument...........................................2099

B. The Sex-Stereotyping Argument ........................................2100

C. Additional Arguments: Sexual-Orientation Discrimination, Antitargeting, and Fundamental Rights ..............................2102

II. EMBRACING THE SEX-DISCRIMINATION ARGUMENT...........................2104

A. The Promise of Formal Equality ..........................................2105

B. The Limited Uptake of Sex Stereotyping ................................2110

III. WHY SO LITTLE TRACTION FOR THE SEX-DISCRIMINATION ARGUMENT IN MARRIAGE CASES?.................................................2113

A. The Judicial Perspective ......................................................2114

B. Theoretical Concerns ..........................................................2118

IV. OTHER POSSIBLE EXPLANATIONS FOR THE SEX-DISCRIMINATION

ARGUMENT'S LIMITED TRACTION ................................................2121

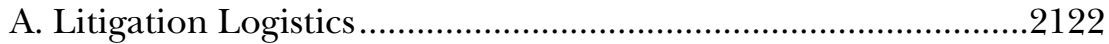

B. Doctrinal Challenges........................................................2124

C. Social-Movement Strategy......................................................2128

D. Psychosocial Explanations .................................................2129

V. The Risky-Argument Frame AND the (FEARED) Social Power of JUDICIAL DECISIONS.............................................................2130

A. Concerns About the Social Power of Legal Reasoning .............2131

B. Avoiding the Risky Argument: A Gay-Rights Case Study ...........2134

VI. RISKY ARGUMENTS: SYNERGIES WITH INCREMENTAL ADVOCACY .........2137

A. The Costs of Sidestepping the Sex-Discrimination Argument..2138

B. The High Impact of Discrete-Argument Wins in Marriage Cases

C. Theorizing the Power of Discrete Arguments in SocialChange Litigation

1. Building on Preexisting Norm Destabilization.

2. Solidifying and Amplifying Preexisting Changes in

Public Discourse and Related Jurisprudence.

D. Retaining a Role for Risky Arguments 


\section{INTRODUCTION}

This Essay takes up the puzzle of the risky argument. In the ordinary course of litigation, advocates present every theory that is likely to persuade, and judges choose among them, usually selecting the arguments that are most compelling without overreaching. But certain theories tend to recede or disappear from advocates' submissions and judicial opinions, even though they have proven fully convincing to some decisionmakers. They turn out to have a lightning-rod-like quality; while some adjudicators find them intensely attractive, others find them repellent. As a result, marginalizing or ignoring them risks losing their persuasive power, yet making them risks provoking otherwise dormant opposition.

The Essay's aim is twofold: first, to theorize about what makes an argument risky in social-justice cases that seek to end discriminatory practices and other inequities, and second, to consider how a risky-argument frame can illuminate the costs and benefits of argumentation choices in litigation and adjudication.

While every argument in social-justice litigation seeks change on the ground, usually through ending a harmful practice or enjoining enforcement of a discriminatory law, some go further. These, which I term "risky arguments," ask decisionmakers to revisit and unsettle deeply rooted or widespread social norms or practices. That is, they not only seek a desired practical outcome but also aim to shift a court's conceptualization of the problem at issue. Put another way, these arguments take direct aim at the presence of discrimination in longstanding laws and practices that tend to be treated, uncritically, as part of the "natural order." In doing so, they pose potentially greater risks than their discrete counterparts.

If they succeed, risky arguments have tremendous upside. Rulings accepting them can often be leveraged to highlight similar discrimination that has gone unnoticed or been deemed unobjectionable in related contexts.

But they have downsides, too. Because the alleged discrimination is so deeply embedded in laws and social practices, these arguments can be difficult for decisionmakers to grasp and may be ineffective as a result. Worse, from a risk perspective, is that their direct challenge to naturalized views may be experienced as threatening. This is because risky arguments, as defined here, ask decisionmakers to find that discrimination is present in generally accepted societal hierarchies (for example, hierarchies associated with the different social roles and expectations of men and women-more on this below) or other familiar practices. ${ }^{1}$

1. Others have written thoughtfully about norm-challenging arguments in connection with a range of civil-rights movements. See, e.g., William N. Eskridge, Jr., Some Effects of Identity-Based Social Movements on Constitutional Law in the Twentieth Century, 100 Mich. L. Rev. 2062, 2064-65 (2002) (discussing constitutional challenges to traditional forms of discrimination brought by movements for racial equality, women's rights, and gay rights); Kenneth L. Karst, Constitutional Equality as a Cultural Form: The 
By urging conceptual shifts rather than minor tweaks in understanding, these norm-challenging arguments risk inciting decisionmakers' Burkean anxieties about the dangers of nonincremental change. ${ }^{2}$ That is, because they challenge the perceived natural order of things, these arguments risk being seen as destabilizing. For some judges, arguments of this sort may prompt a ruling adverse to the argument maker. But, and more interestingly for purposes of this Essay, even those who agree with the litigant's ultimate claim may go out of their way to reject or otherwise disassociate themselves from arguments that directly contest norms embedded in widespread practices.

A couple of concrete examples from outside the marriage-equality context may help illustrate this distinction in argument types. A challenge to the death penalty on the ground that its application to a particular crime or type of defendant is unconstitutionally cruel, for example, is relatively narrow and familiar in conceptual scope. Its practical impact, if accepted, is likewise confined to the particular type of death-penalty case at hand. ${ }^{3}$

By contrast, an argument that the death penalty should be enjoined because the sentencing process is infected by race discrimination would reach more broadly, both conceptually and practically. ${ }^{4}$ Conceptually, the argument would require a court to acknowledge and condemn forms of bias that are arguably both pervasive and deeply entrenched through-

Courts and the Meanings of Sex and Gender, 38 Wake Forest L. Rev. 513, 514-15 (2003) (analyzing the interaction between court decisions and changing social views of women, lesbians, and gay men); Robert C. Post, The Supreme Court, 2002 Term-Foreword: Fashioning the Legal Constitution: Culture, Courts, and Law, 117 Harv. L. Rev. 4, 8 (2003) [hereinafter Post, Fashioning the Legal Constitution] (“ $[\mathrm{C}]$ onstitutional law and culture are locked in a dialectical relationship, so that constitutional law both arises from and in turn regulates culture."); see also Robert C. Post \& Reva Siegel, Roe Rage: Democratic Constitutionalism and Backlash, 42 Harv. C.R.-C.L. L. Rev. 373, 406-30 (2007) (discussing the relationship between developments in constitutional law and cultural politics regarding abortion).

2. See Edmund Burke, Reflections on the Revolution in France 259 (J.C.D. Clark ed., Stanford Univ. Press 2001) (1790) (outlining the risk associated with changes to longsettled political structures because "the whole chain and continuity of the commonwealth would be broken”); see also Cass R. Sunstein, Burkean Minimalism, 105 Mich. L. Rev. 353, 356 (2006) (explaining that "Burkeans insist on incrementalism; but they also emphasize the need for judges to pay careful heed to established traditions"). For discussion of this point in connection with theories of judicial minimalism, see infra note 27.

3. See, e.g., Hall v. Florida, 134 S. Ct. 1986, 1990 (2014) (invalidating Florida statute on Eighth Amendment grounds because it unduly restricted evidence of intellectual disability in death-penalty cases); Roper v. Simmons, 543 U.S. 551, 555 (2005) (barring as "cruel and unusual" executions of individuals for capital crimes committed before age eighteen); Atkins v. Virginia, 536 U.S. 304, 321 (2002) (forbidding, on "cruel and unusual punishment" grounds, execution of individuals with "mental retardation").

4. In McCleskey $v$. Kemp, for example, the Court rejected this broader type of challenge, holding that "a discrepancy that appears to correlate with race" did not require invalidation of Georgia’s death-sentencing process. 481 U.S. 279, 312 (1987). 
out the criminal-justice system. ${ }^{5}$ Practically, a ruling on this ground could be used to challenge not only imposition of the death penalty but also, potentially, most other aspects of the criminal-justice process. ${ }^{6}$ Thus, in both the intellectual move it demands and in its potential reach, the race-discrimination argument involves a bigger "ask" and, hence, greater risk than its more discrete counterpart.

Consider, too, an employment-discrimination suit. A discrete presentation of the case would focus on the set of concrete incidents that led the plaintiff to seek redress, whether in the form of harassment, comments, or undercompensation. ${ }^{7}$ Given the proof difficulties associated with discrimination cases, the same plaintiff might seek to strengthen the case by also making an argument about implicit bias that gave rise to the troublesome workplace conduct or lower payscale. ${ }^{8}$

A favorable ruling based on facts specific to the plaintiff's case would resolve that employee's claim with limited implications for other similar

5. The Court in McCleskey signaled its awareness of the sweep of the race-based equalprotection challenge. "McCleskey challenges decisions at the heart of the State's criminal justice system," the majority wrote. Id. at 297 ("Because discretion is essential to the criminal justice process, we would demand exceptionally clear proof before we would infer that the discretion has been abused.").

For extended discussion of racial bias within the criminal-justice system, see Michelle Alexander, The New Jim Crow 2 (2010) ("Rather than rely on race [to discriminate], we use our criminal justice system to label people of color 'criminals' and then engage in all the practices we supposedly left behind .... We have not ended racial caste in America; we have merely redesigned it.").

6. Cf. Alexander, supra note 5, at 4 (arguing "mass incarceration in the United States had, in fact, emerged as a stunningly comprehensive and well-disguised system of racialized social control").

7. See, e.g., Hall v. Siemens VDO Auto., 481 F. App'x 499, 501 (11th Cir. 2012) (recounting plaintiff's testimony that she received lower compensation than her white male coworkers); Cherry v. Shaw Coastal, Inc., 668 F.3d 182, 185-86 (5th Cir. 2012) (describing pattern of escalating sexual harassment faced by plaintiff from his coworker); Risch v. Royal Oak Police Dep't, 581 F.3d 383, 385-87 (6th Cir. 2009) (citing several instances where male officers with lower test scores were promoted, while plaintiff was repeatedly passed over); White v. Baxter Healthcare Corp., 533 F.3d 381, 385 (6th Cir. 2008) (noting plaintiff's testimony that his new supervisor made multiple discriminatory comments based on race). See generally 1 Andrew J. Ruzicho et al., Employment Law Checklists and Forms $\S 4: 3$ (2014), available at Westlaw EMPL-CF (discussing case law that addresses circumstantial evidence of employment discrimination).

8. See Suzanne B. Goldberg, Discrimination by Comparison, 120 Yale L.J. 728, 734 n.15 (2011) [hereinafter Goldberg, Discrimination by Comparison] (discussing barriers to discrimination plaintiffs' success). For extended discussion about implicit bias in workplaces, see, e.g., Anthony G. Greenwald \& Linda Hamilton Krieger, Implicit Bias: Scientific Foundations, 94 Calif. L. Rev. 945, 946 (2006) (examining "the science of implicit cognition," which "suggests that actors do not always have conscious, intentional control over the processes of social perception, impression formation, and judgment that motivate their actions”); Christine Jolls \& Cass R. Sunstein, The Law of Implicit Bias, 94 Calif. L. Rev. 969, 973 (2006) (discussing how distinctions between intuitive and deliberative cognitive operations can help "illuminate legal responses to a wide range of behavioral problems" regarding implicit bias). 
cases. A ruling on implicit-bias grounds, by contrast, would condemn deeply internalized views and intuitions that, according to many researchers, pervade most workplaces and other segments of society. ${ }^{9}$ This too, needless to say, is a far bigger-and riskier- "ask" than is made by the argument that discriminatory intent can be discerned in the specific incidents at issue. ${ }^{10}$

The same dynamic can be seen in challenges to laws that exclude same-sex couples from marriage or refuse to recognize those couples' existing marriages (together, the "marriage bans"), which serve as the case study for this Essay's extended exploration of risky arguments. In litigation against these bans, two relatively discrete equality arguments feature most prominently ${ }^{11}$ and have proven most likely to prevail. The

9. See Greenwald \& Krieger, supra note 8, at 955 (demonstrating that "implicit attitude measures reveal far more bias favoring advantaged groups than do explicit measures"); see also Audrey J. Lee, Unconscious Bias Theory in Employment Discrimination Litigation, 40 Harv. C.R.-C.L. L. Rev. 481, 483-86 (2005) (summarizing several empirical studies showing "unconscious bias is quite prevalent, often in sharp contrast to individuals' self-professed identity").

10. See Franita Tolson, The Boundaries of Litigating Unconscious Discrimination: Firm-Based Remedies in Response to a Hostile Judiciary, 33 Del. J. Corp. L. 347, 373 (2008) (" $[\mathrm{J}]$ udges also struggle with determining an appropriate remedy for victims of unconscious discrimination that reflects the proper distribution of liability, without causing the employer to engage in behavior that is both costly and overly deterrent."). See generally Goldberg, Discrimination by Comparison, supra note 8, at 791-802 (discussing courts' reluctance to embrace sociological or nonfalsifiable evidence regarding workplace conduct).

A broader issue here is that courts tend to avoid arguments based on evidence that is not easily visible for reasons of institutional competence and legitimacy, among others. See generally Suzanne B. Goldberg, On Making Anti-Essentialist and Social Constructionist Arguments in Court, 81 Or. L. Rev. 629 (2002).

11. Outside of litigation, supporters of marriage equality often make broad fairness arguments as well. See, e.g., David Blankenhorn, Op-Ed, How My View on Gay Marriage Changed, N.Y. Times (June 22, 2012), http://www.nytimes.com/2012/06/23/opinion/ how-my-view-on-gay-marriage-changed.html (on file with the Columbia Law Review) ("Whatever one's definition of marriage, legally recognizing gay and lesbian couples and their children is a victory for basic fairness."); Lincoln Chafee, Gay Marriage: A Question of Fairness, Huffington Post (June 19, 2009, 5:12 AM), http://www.huffingtonpost.com/ lincoln-chafee/gay-marriage-a-question-o_b_217389.html (on file with the Columbia Law Review) ("To me, the issue of same-sex marriage boils down to a question of basic fairness.").

They do not tend to argue, however, that marriage bans discriminate based on sex. This inattention to the sex-discrimination argument in public debates can likely be explained by reasons similar to those explored in this Essay, though development of this point is beyond the scope here. For illustrations of the sex-discrimination argument's infrequent invocation in nonlitigation settings, see, e.g., infra note 24 (discussing legislators and professors who affirm the sex-discrimination argument).

For discussion of the link between the sex-discrimination argument and marriage equality for same-sex couples in public debates of earlier decades, particularly related to the Equal Rights Amendment, see Reva B. Siegel, Constitutional Culture, Social Movement Conflict and Constitutional Change: The Case of the De Facto ERA, 94 Calif. L. Rev. 1323, 1400-02 (2006) [hereinafter Siegel, Constitutional Culture]. 
first is that marriage bans discriminate unconstitutionally based on sexual orientation. The second is that the bans impermissibly target a group of people for an unfair burden (the "antitargeting" argument) and, as such, constitute "[d]iscrimination[] of an unusual character." 12

As will be discussed at length below, the equal-protection argument that focuses on sexual-orientation discrimination is conceptually discrete. Most people understand that the bans primarily affect gay people who want to marry their same-sex partners (disagreement exists only regarding whether the bans are permissible). ${ }^{13}$ The reach of a ruling that marriage bans discriminate impermissibly based on sexual orientation is relatively limited, too, given that few remaining laws or policies discriminate in this way. ${ }^{14}$

The antitargeting argument is also conceptually discrete. It focuses on the bans' enactment in response to the prospect of gay and lesbian couples marrying ${ }^{15}$ and asks the decisionmaker to discern discrimination

12. Romer v. Evans, 517 U.S. 620, 633 (1996) (first alteration in original) (quoting Louisville Gas \& Elec. Co. v. Coleman, 277 U.S. 32, 37-38 (1928)). Romer, the contemporary cornerstone of the antitargeting argument, rejected a state constitutional amendment because it placed a unique legal burden on the ability of lesbians, gay men, and bisexuals to obtain antidiscrimination protections. For Romer's antitargeting predecessors, see City of Cleburne v. Cleburne Living Ctr., Inc., 473 U.S. 432, 435 (1985) (invalidating zoning ordinance that imposed targeted restrictions on housing for people with mental retardation); U.S. Dep't of Agric. v. Moreno, 413 U.S. 528, 538 (1973) (invalidating food-stamp regulation targeted at hippies).

Another frequently made argument, grounded in the due-process guarantee, urges that laws preventing individuals from marrying their same-sex partner or denying recognition to those marriages violate the fundamental right to marry. See infra note 50 and accompanying text (detailing argument and giving various examples).

13. Even Charles Cooper, who defended California's Proposition 8, recognized the exclusion of same-sex couples as discrimination based on sexual orientation, as he argued, in response to a question by Justice Kennedy, that the measure did not discriminate based on sex. See Transcript of Oral Argument at 13-14, Hollingsworth v. Perry, 133 S. Ct. 2652 (2013) (No. 12-144) [hereinafter Hollingsworth Transcript], available at http://www. supremecourt.gov/oral_arguments/argument_transcripts/12-144a.pdf (on file with the Columbia Law Review) ("[W]e agree that to the extent that the classification impacts, as it clearly does, same-sex couples, that-that classification can be viewed as one of sexual orientation rather than $[\mathrm{sex}] . ”)$.

14. Many laws that discriminate based on sexual orientation have recently been overturned. See, e.g., Press Release, Office of the Press Sec'y, White House, Statement by the President on the Repeal of Don't Ask, Don't Tell (Sept. 20, 2011), available at http://www.whitehouse.gov/the-press-office/2011/09/20/statement-president-repealdont-ask-dont-tell (on file with the Columbia Law Review) (announcing formal repeal of “discriminatory law known as Don't Ask, Don't Tell”). However, some laws and policies remain that, in their contexts, discriminate directly based on sexual orientation. See, e.g., Miss. Code Ann. \$93-17-3(5) (2013) ("Adoption by couples of the same gender is prohibited.”); Utah Code Ann. §78B-6-117(3) (LexisNexis 2012) ("A child may not be adopted by a person who is cohabiting in a relationship that is not a legally valid and binding marriage under the laws of this state.").

15. See infra note 53 (discussing "defense of marriage" acts passed after the Hawaii Supreme Court declined to dismiss a lawsuit brought by same-sex couples seeking marriage rights). 
directly from the facts surrounding the enactment and related laws. Its context-specific focus means, too, that a favorable ruling will not translate seamlessly to other kinds of cases.

By contrast, the sex-discrimination argument presents a bigger conceptual ask. ${ }^{16}$ To find sex discrimination, a judge must both see and condemn sex-based distinctions and stereotyping embedded in the different-sex marriage requirement. ${ }^{17}$ But while many people recognize the bans' negative effects on gay people, relatively few perceive sex discrimination in the same rules. This low level of recognition, together with (and perhaps reinforced by) the requirement's longstanding nature and the fact that most married judges have different-sex spouses and many may be in marriages that they see as egalitarian, heightens the challenge of persuading decisionmakers to recognize the presence of sex discrimination in the exclusion of same-sex couples from marriage. ${ }^{18}$

Moreover, a sex-discrimination ruling would likely reach more broadly than a ruling based on sexual-orientation discrimination or an antitargeting theory because numerous officially and socially sanctioned distinctions based on sex remain in force. ${ }^{19}$ There is no obvious reason that a favorable marriage ruling on sex discrimination would not also call some or all of these other distinctions into question. Consequently, the sex-discrimination argument in marriage litigation has the possibility of both the payoff and the downsides that characterize risky arguments.

The next question, then, is whether the risks outweigh the benefits of making, and possibly winning, a case with a broad, norm-challenging theory. This Essay concludes that they sometimes do, though with important qualifications as developed below. My central claim on this point, which is more descriptive than normative, is that a discrete argument has the potential to accomplish much of what the normchallenging argument seeks, without the costs of that argument. This is because a favorable ruling in a social-justice case, regardless of its underlying reasoning, will erode a law or social policy that bolstered the naturalness of the challenged distinction.

16. To be sure, a lawsuit demanding that a state recognize same-sex couples' marriages is itself relatively risky as compared to litigation challenging the federal government's Defense of Marriage Act because regulating marriage is usually the province of the states, not the federal government. See United States v. Windsor, 133 S. Ct. 2675, 2691 (2013) ("[T]he Federal Government, through our history, has deferred to state-law policy decisions with respect to domestic relations."). But this is separate from the question whether the legal theories advanced in a given lawsuit are conceptually discrete or are more broadly, and riskily, norm challenging.

17. For elaboration of these two sex-discrimination theories, see infra Part I.A-B.

18. See infra Part IV.B (exploring doctrinal barriers to the sex-discrimination argument, including case law on dress codes and parenting); Part IV.D (offering a psychosocial explanation for judicial reluctance to accept sex-discrimination arguments).

19. See infra note 170 (discussing social norms regarding different-sex bathrooms); see also infra note 158 (discussing pervasive, popular beliefs in essential differences between men and women). 
In other words, a ruling can undermine stereotypes and conventions without relying on, or even mentioning, a theory that directly confronts them..$^{20}$ There are other benefits of sidestepping the "big" argument, too, including reducing the likelihood of alienating potential allies and the risk of a broadly damaging loss. Of course, there are also costs associated with not making these arguments, which this Essay will detail as well. ${ }^{21}$

A few more general observations are needed before turning to explore in depth the sex-discrimination argument in marriage cases through the lens of the risky-argument theory. First, while any number of arguments might seek to expand judicial understandings of discrimination, this Essay's interest is in those that have already been accepted by audiences beyond their proponents and close allies. That is, the arguments must have been deemed plausible by some courts, have serious empirical support, or have some other indicia of mainstream acceptance. This is not to suggest that all previously unembraced arguments lack value. Rather, my aim here is to understand why certain arguments do not get much traction, either among advocates or judges, even after they have proven to be persuasive.

By looking at arguments with demonstrated plausibility, we can start to see that some arguments are disfavored or disregarded by advocates, or rejected by judges, not because they are unpersuasive but rather for reasons related to the confrontation they seek with the status quo. It is this confrontation that makes them riskier or less appealing than other available arguments. Yet because they appeal to some, there is risk not only in making them, but also in sidestepping them.

The marriage-equality context is particularly interesting in this vein. On the one hand, the sex-discrimination argument is "obviously correct" to some judges, ${ }^{22}$ scholars, ${ }^{23}$ and others. ${ }^{24}$ Indeed, it may persuade decicases).

20. See infra Part VI.B (discussing high impact of discrete-argument wins in marriage

21. One qualification is important here. Advocates often decline to make arguments that will cut against their broader goals in ways that might harm other clients. The risky arguments discussed here do not fall into this category for the reasons explained below.

22. See, e.g., Latta v. Otter, Nos. 14-35420, 14-35421, 12-17668, 2014 WL 4977682, at *15 (9th Cir. Oct. 7, 2014) (Berzon, J., concurring) ("[T]he same-sex marriage prohibitions, if anything, classify more obviously on the basis of sex than they do on the basis of sexual orientation ...."); see also infra text accompanying notes 53-68 (discussing judicial decisions endorsing the sex-discrimination argument).

23. See infra text accompanying notes 80-84 (discussing scholarly support for the sex-discrimination argument).

24. See Conn. Senate Judiciary Comm., Reports on Bills Favorably Reported by Committee: An Act Concerning Marriage Equality, S.B. 963 (2005), available at http:// www.cga.ct.gov/2005/jfr/s/2005SB-00963-R00JUD-JFR.htm (on file with the Columbia Law Review) (quoting law professors Ian Ayres and Jennifer Brown as supporting Connecticut bill to legalize marriage for same-sex couples because "Connecticut should end the sex discrimination in the law"); Phil Reese, Kaine, Two More U.S. Senators Back Marriage Equality, Wash. Blade (Mar. 26, 2013), http://www.washingtonblade.com/2013/03/26/ kaine-two-more-u-s-senators-back-same-sex-marriage (on file with the Columbia Law Review) 
sionmakers who are otherwise unmoved or reluctant to embrace antitargeting or sexual-orientation-discrimination arguments. It may also be a valuable "atmospheric" argument that, while not ultimately adopted, helps a decisionmaker along in finding fault with the challenged law. ${ }^{25} \mathrm{At}$ the same time, it is also obviously incorrect to others and, at times, provocatively so. Some judges who rule for marriage equality on other grounds and, therefore, do not need to address the sex-discrimination argument at all will nonetheless make a point of explaining why they reject it. ${ }^{26}$ In this way, there is peril both in making and in avoiding or marginalizing the argument.

This inescapable risk helps explain why one cannot simply dismiss risky arguments as antiminimalist and, therefore, not worth making. As Cass Sunstein wrote, within a broader exploration of judicial minimalism, courts "generally try to avoid issues of basic principles" in cases with high societal stakes. ${ }^{27}$ Yet it will sometimes be the case, perhaps especially in social-justice cases, that what makes a particular argument nonminimalist is in the eye of the beholder. Arguments that one judge sees as entailing a measurable societal shift may be seen by another judge as narrow or necessary to reach a litigant's desired outcome.

Further, the risky-argument frame helps clarify that the set of "minimalist" arguments in a given context is also not fixed. What constitutes a basic principle that might best be avoided, per Sunstein, will change over time, depending on shifts in surrounding law and social

(quoting Senator Jay Rockefeller as supporting marriage rights for same-sex couples because "government shouldn't discriminate against people who want to marry just because of their gender").

25. The argument can help illuminate why certain proffered justifications, such as the state's interest in children having both male and female parents, are laden with sex stereotypes. See infra notes 189-190 and accompanying text (discussing the use of sexdiscrimination argument to expose impermissible gender-role stereotypes).

26. See infra notes 101-108 and accompanying text (discussing rulings in which courts granted litigants' marriage-equality claim and rejected the sex-discrimination argument rather than leaving it unaddressed).

27. See Cass R. Sunstein, The Supreme Court, 1995 Term-Foreword: Leaving Things Undecided, 110 Harv. L. Rev. 4, 20 (1996) (describing "incompletely theorized agreements" as one goal of judicial minimalists (emphasis omitted)). Social-change cases will often fit Sunstein's characterization as involving issues "of high complexity about which many people feel deeply and on which the nation is in flux (moral or otherwise)." Id. at 8 . For these kinds of cases, Sunstein suggests that "minimalism makes sense first because courts may resolve the relevant issues incorrectly, and second because courts may be ineffective or create serious problems even if their answers are right." Id. Consequently, he argues, "[c] ourts should try to economize on moral disagreement by refusing to challenge other people's deeply held moral commitments when it is not necessary for them to do so." Id.

The focus here is not so much on the normative justifications for or the desirability of judicial minimalism, but on the second-order reasons why some arguments come to be seen as "bigger" and therefore less minimalist and more threatening than others. 
norms. In other words, an argument that is minimalist at one time might be seen as much less so at another. ${ }^{28}$

This is certainly the case in marriage litigation. As discussed below, arguments about sexual-orientation discrimination might once have been seen as risky because of their implications for other sexualorientation-based laws and because of prevailing norms that supported inequality for gay people. ${ }^{29}$ Yet these same arguments have undergone a status shift and, arguably, have become minimalist in an environment where legal enforcement of sexual-orientation discrimination is increasingly disdained. ${ }^{30}$ Similarly, arguments that bans related to same-sex couples' marriages engage in impermissible targeting and amount to discrimination of an unusual character (the argument the Supreme Court accepted in United States $v$. Windsor ${ }^{31}$ ) have also become more minimalist since the Court decided, in Romer $v$. Evans, to apply our constitutional tradition of concern in this regard to an antigay measure.

The remainder of the Essay explores, through the risky-argument frame advanced here, why the sex-discrimination argument has not gotten much traction in marriage cases and what broader consequences may flow from this risky-argument avoidance. On this point, particular consideration goes to the sex-discrimination argument's synergies with

28. In Jack Balkin's terms, this would be the shift when an argument moves from being "off-the-wall" to "on-the-wall." Jack M. Balkin, Constitutional Redemption 12, 17783 (2011). In a similar vein, Justice Ginsburg invoked Paul Freund's observation that judges "are affected, not by the weather of the day ... but by the climate of the era" to explain courts' growing amenability to women's rights claims in the 1970s. Ruth Bader Ginsburg, Constitutional Adjudication in the United States as a Means of Advancing the Equal Stature of Men and Women Under the Law, 26 Hofstra L. Rev. 263, 268 (1997). She added:

Supreme Court Justices, and lower court judges as well, were becoming aware of a sea change in United States society. Their enlightenment was advanced publicly by the briefs filed in Court and privately, I suspect, by the aspirations of the women, particularly the daughters and granddaughters, in their own families and communities.

Id. at 268-69.

For a discussion of the process by which changed understandings of a social group are incorporated into legal doctrine, see generally Suzanne B. Goldberg, Constitutional Tipping Points: Civil Rights, Social Change, and Fact-Based Adjudication, 106 Colum. L. Rev. 1955 (2006).

29. Cf. Bowers v. Hardwick, 478 U.S. 186, 196 (1986) (sustaining Georgia's sodomy law based on "majority sentiment about the morality of homosexuality"); id. at 196-97 (Burger, C.J., concurring) (stating that "[d]ecisions of individuals relating to homosexual conduct have been subject to state intervention throughout the history of Western civilization" based on "millennia of moral teaching").

30. See, e.g., Lawrence v. Texas, 539 U.S. 558, 578 (2003) (invalidating Texas's "homosexual conduct" law, overruling Bowers, and concluding that the gay litigants were "entitled to respect for their private lives").

31. 133 S. Ct. 2675, 2692 (2013) (quoting Romer v. Evans, 517 U.S. 620, 633 (1996)). 
narrower or more minimalist arguments that may contribute to litigation success even when courts do not take up the argument directly. ${ }^{32}$

To set a foundation for the discussion that follows, Part I offers a primer on the sex-discrimination argument and other legal theories presented in marriage-equality cases. Part II then elaborates the enthusiastic judicial and scholarly embrace that the sex-discrimination argument has received in some quarters. As Part III shows, however, most judges have ignored the argument, including in Windsor, and some judges and scholars have made a special point of rejecting it even when they grant marriage-equality claims.

Part IV then tracks several possible explanations for the sexdiscrimination argument's evanescence in marriage litigation. These include practical reasons related to word limits and judicial attention spans; broader reasons associated with doctrine and social-movement strategy; and psychosocial explanations related to the advocates and judges who decide whether and how to address the arguments.

Part V uses the risky-argument frame to show that courts may also resist the sex-discrimination argument because of inchoate beliefs that adopting the argument will produce undesirable shifts in social norms and relations. Building on earlier observations, Part VI explores the role that risky arguments play in litigation even when they do not receive judicial uptake. In particular, this Part considers the synergies between

32. Although the sex-discrimination argument can be both useful and effective, as the discussion below shows, this Essay does not develop that position at length here. Instead, it focuses on the potential risks associated with the argument in an effort to understand its limited uptake.

For thoughtful development of the sex-discrimination argument's benefits in litigation and policy debates, see, e.g., Susan Frelich Appleton, Missing in Action? Searching for Gender Talk in the Same-Sex Marriage Debate, 16 Stan. L. \& Pol'y Rev. 97, 125-34 (2005) (arguing that "add[ing] explicit gender talk to the public conversation ... will both expose and answer the reliance on implicit gender talk by same-sex marriage opponents"); Mary Anne Case, "The Very Stereotype the Law Condemns": Constitutional Sex Discrimination Law as a Quest for Perfect Proxies, 85 Cornell L. Rev. 1447, 1486-90 (2000) [hereinafter Case, The Very Stereotype] ("[T]o strike down a ban on same-sex marriage on equal protection grounds as violative of norms against sex discrimination rather than on substantive due process grounds as violative of guarantees of associational privacy and family autonomy, is in many respects the more conservative, more easily limited decision."); Mary Anne Case, What Feminists Have to Lose in Same-Sex Marriage Litigation, 57 UCLA L. Rev. 1199, 1221 (2010) [hereinafter Case, What Feminists Have to Lose] (explaining that the sex-discrimination argument's focus on stereotyping "obviates the necessity of forcing individuals into well-defined rigid groups to whose standards they must conform-gay or straight, male or female, masculine or feminine-as a precondition for vindicating their rights"); Deborah A. Widiss, Elizabeth L. Rosenblatt \& Douglas NeJaime, Exposing Sex Stereotypes in Recent Same-Sex Marriage Jurisprudence, 30 Harv. J.L. \& Gender 461, 479-87 (2007) (observing that "grounding the facial sex discrimination argument in a substantive discussion of the sex stereotypes at play can make the sex discrimination caused by the use of sex-based classifications in the marriage statutes much more real" because "sex stereotypes continue to have significant currency today" (emphasis omitted)). 
risky and more discrete or incremental arguments, and the benefits those synergies might produce for litigants in social-change cases.

\section{A PRIMER ON THE SEX-DiscriminATION ARGUMENT AND OTHER LEGAL THEORIES IN MARRIAGE CASES}

The sex-discrimination argument in marriage cases has two dimensions-one focused on formal equality and the other on sex stereotyping. This Part discusses how each is presented by advocates and sets the foundation for discussion to come about the sex-discrimination argument's lack of traction and its various costs and benefits. To put the sex-discrimination argument in context, this Part will also briefly address how the sexual-orientation and antitargeting equality arguments and the fundamental-rights due process argument are framed in marriage cases.

\section{A. The Formal-Equality Argument}

First, and most popular among litigators and judges, ${ }^{33}$ is the formalequality argument, which focuses on facial discrimination. Here, the claim is that a law authorizing a man to marry a woman but not to marry a man (and a woman to marry a man but not a woman) is discriminatory per se based on the category of sex. Put another way, a rule that limits marriage to different-sex couples hinges eligibility on the sex of one's partner. According to the formal-equality argument, this kind of sexbased eligibility rule is, by definition, discrimination based on sex.

When litigators include this equal-protection argument in their complaints, they frame it in similarly simple terms. In the first successful challenge to the federal Defense of Marriage Act (DOMA), Gill v. Office of Personnel Management, the complaint alleged:

[I]f Keith were married to a woman, not a man, he would be entitled to the issuance of a United States passport in his legal surname after marriage upon presenting a copy of the marriage certificate to the State Department. Because of DOMA . . Keith was treated differently from a similarly situated person married to an individual of a different sex. ${ }^{34}$

Likewise, in the challenge to California's Proposition 8, while the complaint focused primarily on sexual-orientation discrimination, it

33. The academic literature, by contrast, has given the antistereotyping argument greater attention. See supra note 32 (referencing scholarly discussion of sexdiscrimination argument's benefits); see also infra note 38 (highlighting additional scholarly treatment of the sex-stereotyping argument).

34. Complaint for Declaratory, Injunctive, or Other Relief \& for Review of Agency Action at 84, Gill v. Office of Pers. Mgmt., 699 F. Supp. 2d 374 (D. Mass. 2010) (No. 0910309-JLT), available at http://www.glad.org/uploads/docs/cases/gill-v-office-of-person nel-management/gill-complaint-03-03-09.pdf (on file with the Columbia Law Review).

For an extended discussion of plaintiffs' litigation strategies in marriage-ban cases, including discussion of how the arguments are characterized in briefs, see Widiss et al., supra note 32 , at $464-75$. 
added an equal-protection count to make the formal sex-discrimination argument:

Prop. 8 also violates the Equal Protection Clause because it discriminates on the basis of sex. It distinguishes between couples consisting of a man and a woman and couples consisting of individuals of the same sex. Thus, the limitation on civil marriage depends upon an individual person's sex; a man who wishes to marry a man may not do so because he is a man, and a woman may not marry a woman because she is a woman. ${ }^{35}$

Still other complaints present claims of sex- and sexual-orientation discrimination together, as in this DOMA challenge to the federal government's refusal to grant health benefits to an employee with a same-sex spouse: "If Ms. Golinski were a man, . . . [she] would be able to add her spouse to her existing family plan at no additional cost to her. Similarly situated heterosexual employees in Ms. Golinski's position routinely receive this significant benefit as a matter of course." 36

\section{B. The Sex-Stereotyping Argument}

The other version of the sex-discrimination argument focuses on sex stereotyping. Here the claim is that by restricting marriage to differentsex couples, a state is presuming-or insisting-that men and women perform different roles in marriage and that the different roles are rooted in their maleness and femaleness. ${ }^{37}$ If a marriage law intentionally instantiates a sex-role difference, the law then conflicts with settled equalprotection jurisprudence that governments may not enforce rules based on gender stereotypes. ${ }^{38}$ And if a state denies that it seeks to enforce sex

35. Complaint for Declaratory, Injunctive, or Other Relief at 9, Perry v. Schwarzenegger, 704 F. Supp. 2d 921 (N.D. Cal. 2010), aff'd sub nom. Perry v. Brown, 671 F.3d 1052 (9th Cir. 2012), vacated and remanded sub nom. Hollingsworth v. Perry, 133 S. Ct. 2652 (2013) (No. 3:09-cv-02292-VRW) [hereinafter Perry Complaint], 2009 WL 1490740 .

36. Second Amended Complaint at 4, Golinski v. Office of Pers. Mgmt., 824 F. Supp. 2d 968 (N.D. Cal. 2012) (No. 3:10-cv-0257-JSW), 2011 WL 1481482.

37. For historical discussion of marriage's different role assignments for men and women, see generally Suzanne B. Goldberg, A Historical Guide to the Future of Marriage for Same-Sex Couples, 15 Colum. J. Gender \& L. 249, 249-53 (2006) (describing the way in which "misconceptions of marriage's history have played such an important part in justifying the male-female marriage eligibility requirement").

38. See, e.g., J.E.B. v. Alabama ex rel. T.B., 511 U.S. 127, 130-31, 139 (1994) (rejecting "gross generalizations" based on sex and discrimination that "serve[] to ratify and perpetuate invidious, archaic, and overbroad stereotypes about the relative abilities of men and women"). For further discussion of this argument in legal scholarship, see, e.g., Case, What Feminists Have to Lose, supra note 32, at 1221 (arguing "antidifferentiation or antistereotyping view" is "an independently important guarantee of liberty"); Edward Stein, Evaluating the Sex Discrimination Argument for Lesbian and Gay Rights, 49 UCLA L. Rev. 471, 498 (2001) ("The sociological claim is that laws that discriminate on the basis of sexual orientation disadvantage women as well as lesbians, gay men, and bisexuals because these laws perpetuate a social system in which women play different social roles 
roles in this way, then the law allowing marriage only to male-female pairs would be impermissibly arbitrary.

In litigation, this version of the sex-discrimination argument tends to be presented simplistically in complaints,${ }^{39}$ if at all, with a framing along the same conceptual lines as the formal-equality argument. In a challenge to Nevada's marriage restriction, for example, the complaint asserted that "the State's marriage ban serves the impermissible purpose of blocking departures from sex stereotypes by excluding each Plaintiff from marriage ... because Plaintiffs fail to conform to the prevailing and State-enforced stereotype that men should marry women and that women should marry men." ${ }^{40}$ There is opportunity to develop the argu-

than men. The theoretical claim is that these laws are justified by sexism."); see also infra notes 83-84 and accompanying text (discussing link between sexuality-based and genderbased discrimination).

39. Complaints often present a reduced version of a complex argument. In large part, this is because the litigation function of the complaint is to set out sufficient facts to overcome a motion to dismiss, if one is made, and to provide a framework for discovery. After the motion-to-dismiss phase of litigation has passed, the complaint is typically no longer the centerpiece of the litigation; focus turns instead to evidence gained through discovery and to the lawyers' briefs and elaborated arguments in subsequent motions. Compare, e.g., Fed. R. Civ. P. 12(b) (6) (placing complaint's allegations as central concern in motion to dismiss), with Fed. R. Civ. P. 56(c) (focusing the dispositive summaryjudgment motion on pleadings, depositions, answers to interrogatories, admissions, and affidavits, rather than on the complaint's allegations).

In much litigation, however, including social-justice cases, complaints go beyond the bare minimum required by the Federal Rules of Civil Procedure and focus on telling a particular advocacy story. For a broader discussion of advocacy through complaint drafting, see Herbert A. Eastman, Speaking Truth to Power: The Language of Civil Rights Litigators, 104 Yale L.J. 763, 768-72 (1995) (emphasizing "persuasiveness of the stories" civil-rights lawyers can tell on behalf of their clients through the complaint).

40. Complaint for Declaratory \& Injunctive Relief at 28, Sevcik v. Sandoval, 911 F. Supp. 2d 996 (D. Nev. 2012) (No. 2:12-cv-00578-RCJ-PAL), 2012 WL 1190622; see also, e.g., Complaint for Declaratory \& Injunctive Relief at 30, Darby v. Orr, No. 12CH19718 (Ill. Cir. Ct. May 30, 2012), available at http://www.lambdalegal.org/sites/default/files/ darby_il_20120530_complaint-declaratory-injunctive-relief.pdf (on file with the Columbia Law Review) (“[T]he State's marriage ban serves the impermissible purpose of blocking departures from sex stereotypes ...."); Complaint for Declaratory \& Injunctive Relief at 31, Lazaro v. Orr, No. 12 CH19719 (Ill. Cir. Ct. May 30, 2012), 2012 WL 1941374 (asserting that restrictions on same-sex couples' marriage "on the basis of stereotype" constitutes sex discrimination).

Although this type of presentation closely tracks the formal-discrimination argument, some courts react to stereotyping claims as though they are relatively complex. A federal district court in Wisconsin, for example, described the stereotyping argument as "more nuanced" than the "straightforward" facial-discrimination theory. Wolf v. Walker, $986 \mathrm{~F}$. Supp. 2d 982, 1007 (W.D. Wis.), aff'd sub nom. Baskin v. Bogan, 766 F.3d 648 (7th Cir.), cert. denied, No. 14-278, 2014 WL 4425163 (U.S. Oct. 6, 2014). The plaintiffs had briefed their stereotyping theory by arguing that the denial of marriage to same-sex couples "perpetuates and enforces stereotypes regarding the expected and traditional roles of men and women, namely that men marry and create families with women, and women marry and create families with men." Reply Memorandum in Support of Plaintiffs' Motion for Summary Judgment at 18, Wolf, 986 F. Supp. 2d 982 (No. 3:14-cv-00064-bbc), 2014 WL 2572131. 
ment more extensively in briefing, and amicus briefs in contemporary marriage litigation often do that. ${ }^{41}$ But the parties' briefs typically do not, ${ }^{42}$ and it is those briefs that signal the litigants' priorities to the court.

\section{Additional Arguments: Sexual-Orientation Discrimination, Antitargeting, and Fundamental Rights}

Complaints and briefs challenging marriage bans have typically led with a simply framed sexual-orientation-discrimination argument rather than either version of the sex-discrimination argument just described. The Windsor complaint, for example, included only one count, which

41. See, e.g., Amici Curiae Brief of the National Women's Law Center et al. in Support of Plaintiffs-Appellees \& Affirmance at 14-21, DeBoer v. Snyder, No. 14-1341, 2014 WL 5748990 (6th Cir. Nov. 6, 2014) [hereinafter NWLC Tanco Brief], available at http://williamsinstitute.law.ucla.edu/wp-content/uploads/Tanco-Brief-June-2014.pdf (on file with the Columbia Law Review) (developing the argument that "[1]aws that classify based on sexual orientation typically share with laws that discriminate based on sex a foundation in gender stereotypes"). Similar briefs have been filed on appeal in numerous other challenges to state bans on marriage and on marriage recognition for same-sex couples. See, e.g., Amici Curiae Brief of the National Women's Law Center et al. in Support of Plaintiffs-Appellees \& Affirmance at 14-21, Baskin v. Zoeller, No. 14-2386 (7th Cir. Aug. 5, 2014) [hereinafter NWLC Baskin Brief], available at http://www.nwlc.org/sites/default/files/pdfs/cx_ab_marriage_equality_20140805.pdf (on file with the Columbia Law Review) (making arguments nearly identical to those in National Women's Law Center's amicus brief filed in Tanco).

42. See, e.g., Brief for Respondents at 29-35, Hollingsworth v. Perry, 133 S. Ct. 2652 (2013) (No. 12-144), 2013 WL 648742 (arguing for heightened scrutiny based on the challenged measure's sexual-orientation classification and omitting a sex-discrimination claim). But see, e.g., Brief in Support of Plaintiffs' Motion for Summary Judgment at 2327, Harris v. McDonnell, 988 F. Supp. 2d 603 (W.D. Va. 2013) (No. 5:13-cv-00077) [hereinafter Harris Plaintiffs' Motion for Summary Judgment Brief], available at https://www.aclu.org/sites/default/files/assets/50.2_-_brief_in_support_of_pls_motion_ for_summary_judgment_-_9.30.13.pdf (on file with the Columbia Law Review) (arguing for heightened scrutiny of Virginia's marriage bans not only because of the sexual-orientationbased classification but also because "they classify explicitly based on gender, and they reflect stereotyped notions of the proper role of men and women in the marital and family contexts"). For more detailed discussion of litigants' lower-court briefing of the sexdiscrimination argument in the pre-Windsor context, see Widiss et al., supra note 32, at 464-73.

In Edith Windsor's case, the sex-discrimination argument was absent from the complaint, see infra note 43 , and much of the litigation. It arose only in a footnote in Windsor's Supreme Court brief, though not as an affirmative argument. Instead, the brief noted the defendant-intervenor Bipartisan Legal Advisory Group's “curious suggestion that DOMA 'does not classify based on a married couple's sexual orientation,' because it is theoretically possible that a man and a woman, each of whom is gay, would marry each other and be treated as married." Brief on the Merits for Respondent Edith Schlain Windsor at 18 n.2, United States v. Windsor, 133 S. Ct. 2675 (2013) (No. 12-307) [hereinafter Windsor Respondent's Merits Brief], available at http://www.americanbar. org/content/dam/aba/publications/supreme_court_preview/briefs-v2/12-307_resp_meri ts.authcheckdam.pdf (on file with the Columbia Law Review). Windsor's lawyers wrote that "[i]f the Court were to accept that reading of DOMA . . . then DOMA would constitute sex discrimination.” Id. 
characterized the injury exclusively in terms of sexual orientation: "Because the federal government defers to New York's determination of who is married for all married couples in New York except married samesex couples, DOMA discriminates on the basis of sexual orientation." 43

Other complaints present the claim in comparable terms. In a Texas suit, for example, the complaint alleged: "By explicitly denying civil marriage to same-sex couples, Texas's ban on same-sex marriage discriminates on the basis of sexual orientation." 44 A marriage lawsuit in Virginia made essentially the same assertion: "By purposefully denying civil marriage to gay and lesbian individuals, Virginia's ban on same-sex marriage discriminates on the basis of sexual orientation." 45

Some complaints also present a separate antitargeting count, derived from Romer and related cases, that governments may not target a group based on popular hostility or disapproval. ${ }^{46}$ In the Texas complaint, the argument took this form: "The disadvantage Texas imposes on same-sex couples is the result of disapproval or animus against a politically unpopular group." ${ }^{47}$ Likewise, in Utah, the complaint alleged:

Amendment 3 and the Marriage Discrimination Statutes "place[] the force of law behind stigmas against gay men and lesbians, including: gay men and lesbians do not have intimate relationships similar to heterosexual couples; gay men and

43. Amended Complaint at 21, Windsor v. United States, 833 F. Supp. 2d 394 (S.D.N.Y.), aff'd, 699 F.3d 169 (2d Cir. 2012), aff'd, 133 S. Ct. 2675 (2013) (No. 10 Civ. 8435 (BSJ) (JCF)), 2011 WL 1302444. This Essay returns to the costs and benefits of the decision to leave out the sex-discrimination argument in Part VI.

44. Plaintiff's Original Complaint for Declaratory \& Injunctive Relief at 14, De Leon v. Perry, 975 F. Supp. 2d 632 (W.D. Tex. 2014) (No. 5:13-cv-982) [hereinafter De Leon Complaint], 2013 WL 5969882.

45. Complaint for Declaratory, Injunctive \& Other Relief at 9, Bostic v. Rainey, $970 \mathrm{~F}$. Supp. 2d 456 (E.D. Va.), aff'd sub nom. Bostic v. Schaefer, 760 F.3d 352 (4th Cir.), cert. denied, No. 14-225, 2014 WL 4230092 (U.S. Oct. 6, 2014) (No. 2:13cv935), 2013 WL 4050615 .

46. See Romer v. Evans, 517 U.S. 620, 634-35 (1996) (“[L]aws of [this] kind . . raise the inevitable inference that the disadvantage imposed is born of animosity toward the class of persons affected ... [which offends] conventional and venerable [principles]."); City of Cleburne v. Cleburne Living Ctr., Inc., 473 U.S. 432, 448 (1985) (rejecting "mere negative attitudes" or "fear" as grounds for singling out a group for burdensome regulation); U.S. Dep't of Agric. v. Moreno, 413 U.S. 528, 534 (1973) (concluding equalprotection guarantee "must at the very least mean that a bare congressional desire to harm a politically unpopular group cannot constitute a legitimate government interest" to justify disparate treatment of that group); see also supra note 31 and accompanying text (discussing Supreme Court's acceptance of the antitargeting argument in Windsor). Russell Robinson has offered a thoughtful critique of the linkage among these three cases, while situating them more broadly in the Court's current equal-protection jurisprudence. Russell K. Robinson, Unequal Protection, 67 Stan. L. Rev. (forthcoming 2015) (manuscript at 9-15, 26-27), available at http://ssrn.com/abstract=2476714 (on file with the Columbia Law Review).

47. De Leon Complaint, supra note 44, at 14. 
lesbians are not as good as heterosexuals; and gay and lesbian relationships do not deserve the full recognition of society." 48

And in California, the Perry complaint advanced the antitargeting argument in this way: "The disadvantage Prop. 8 imposes upon gays and lesbians is the result of disapproval or animus against a politically unpopular group." 49

Finally, most complaints also include an allegation that denying marriage to same-sex couples infringes the right to marry, which the Supreme Court has long recognized as fundamental. ${ }^{50}$ In Kentucky, for example, the plaintiffs' complaint asserted that "Kentucky law denies the Plaintiff couple and other same-sex couples this fundamental right by denying them access to the state-recognized institution of marriage and refusing to recognize the marriages they entered into in other states and countries."51 The fundamental-rights claim in the Perry complaint was similar: "Prop. 8 impinges on fundamental liberties by denying gay and lesbian individuals the opportunity to marry civilly and enter into the same officially sanctioned family relationship with their loved ones as opposite-sex individuals." 52

\section{EMBRACING THE SEX-DISCRIMINATION ARGUMENT}

Before investigating the sex-discrimination argument's limited traction in marriage cases, it is important to see that the argument receives sufficient judicial uptake to make the inquiry worthwhile. Here, I discuss judicial acceptance of the formal-equality version of the sex-

48. Complaint for Declaratory \& Injunctive Relief at 13-14, Kitchen v. Herbert, 961 F. Supp. 2d 1181 (D. Utah 2013), aff'd, 755 F.3d 1193 (10th Cir.), cert. denied, No. 14124, 2014 WL 3841263 (U.S. Oct. 6, 2014) (No. 2:13-cv-00217-RJS) (quoting Perry v. Schwarzenegger, 704 F. Supp. 2d 921, 973 (N.D. Cal. 2010), aff'd sub nom. Perry v. Brown, 671 F.3d 1052 (9th Cir. 2012), vacated and remanded sub nom. Hollingsworth v. Perry, 133 S. Ct. 2652 (2013)), 2013 WL 1287377.

49. Perry Complaint, supra note 35, at 9 .

50. See, e.g., Zablocki v. Redhail, 434 U.S. 374, 383 (1978) (explaining that "our past decisions make clear that the right to marry is of fundamental importance" and the "freedom to marry has long been recognized as one of the vital personal rights essential to the orderly pursuit of happiness by free men" (quoting Loving v. Virginia, 388 U.S. 1, 12 $(1967)))$. The Fourth Circuit recently accepted the fundamental-right-to-marry argument advanced by the litigants. See Bostic, 760 F.3d at 376 ("[W]e conclude that the fundamental right to marry encompasses the right to same-sex marriage ...."); see also Latta v. Otter, Nos. 14-35420, 14-35421, 12-17668, 2014 WL 4977682, at*11-*13 (9th Cir. Oct. 7, 2014) (Reinhardt, J., concurring) (stating that "the fundamental right to marriage, repeatedly recognized by the Supreme Court . . is properly understood as including the right to marry an individual of one's choice" and "that right applies to same-sex marriage just as it does to opposite-sex marriage").

51. Amended Complaint for Declaratory \& Injunctive Relief para. 88, Bourke v. Beshear, 996 F. Supp. 2d 542 (W.D. Ky.), rev'd sub nom. DeBoer v. Snyder, No. 14-1341, 2014 WL 5748990 (6th Cir. Nov. 6, 2014) (No. 3:13-cv-00750-JGH), 2013 WL 4701355.

52. Perry Complaint, supra note 35 , at 8 . 
discrimination argument first and then turn to courts' embrace of the sex-stereotyping theory.

\section{A. The Promise of Formal Equality}

The formal-equality argument began with great promise in marriage litigation, as it carried the day in the very first appellate decision in the United States to recognize that excluding same-sex couples from marriage could be unconstitutional..$^{53}$ A plurality of the Hawaii Supreme Court in Baehr $v$. Lewin held that the plaintiff couples had stated a sexdiscrimination claim on which relief could be granted and deemed the issue to be an easy one. ${ }^{54}$ " $[\mathrm{O}] \mathrm{n}$ its face and as applied," the court wrote, the challenged Hawaii marriage law "regulates access to the marital

53. Baehr v. Lewin, 852 P.2d 44 (Haw. 1993). It was the Hawaii Supreme Court's ruling, based on the state's Equal Rights Amendment, that prompted Congress to enact the Defense of Marriage Act at the federal level and prompted states to enact similar legislation in their own jurisdictions. Hawaii, Freedom to Marry, http://www.freedomto marry.org/states/entry/c/hawaii (on file with the Columbia Law Review) (last visited Sept. 18, 2014) (outlining history of same-sex couples' marriage-recognition efforts in Hawaii). Hawaii voters amended the state constitution to ban same-sex couples from marrying before the case was finally decided. Id. In late 2013, the legislature reversed course and recognized marriage rights for same-sex couples. Id.

A Maryland trial court reached a similar conclusion over a decade later based on Maryland's Equal Rights Amendment, though its analysis was rejected by the state supreme court. Deane v. Conaway, No. 24-C-04-005390, 2006 WL 148145, at*3 (Md. Cir. Ct. Jan. 20, 2006) ("The relative genders of the two individuals . . lie at the very center of the matter; those whose genders are the same as their intended spouses may not marry, but those whose genders are different from their intended spouses may. This Court, therefore, concludes that [the marriage ban] discriminates based on gender."), rev'd, 932 A.2d 571 (Md. 2007).

Baehr helped to initiate a second wave of marriage litigation and legislative advocacy efforts on behalf of same-sex couples in the United States. See William N. Eskridge, Jr., Backlash Politics: How Constitutional Litigation Has Advanced Marriage Equality in the United States, 93 B.U. L. Rev. 275, 281 (2013) [hereinafter Eskridge, Backlash Politics] ("Inspired by the Hawaii litigation's vision of marriage equality, gay marriage activists in other states engaged in more clever institutional strategies and enjoyed greater public attention to the increasing number of committed lesbian and gay couples . ...”).

In the first wave, litigant couples uniformly lost their appeals in rulings that contained relatively little analysis by comparison to more recent rulings. See Jones v. Hallahan, 501 S.W.2d 588, 590 (Ky. Ct. App. 1973) (rejecting challenge to marriage law's exclusion of gay couples); Baker v. Nelson, 191 N.W.2d 185, 186 (Minn. 1971) (same); DeSanto v. Barnsley, 476 A.2d 952, 952 (Pa. Super. Ct. 1984) (same); Singer v. Hara, 522 P.2d 1187, 1197 (Wash. Ct. App. 1974) (same). For a related typology of developments in marriage litigation and legislative advocacy, see Eskridge, Backlash Politics, supra, at 279-91 (describing three stages of advocacy related to marriage equality).

54. The Baehr plurality "effectively became the opinion of the court" when a newly appointed associate justice, Paula Nakamaya, joined a later court order clarifying the original plurality opinion. Andrew Koppelman, Why Discrimination Against Lesbians and Gay Men Is Sex Discrimination, 69 N.Y.U. L. Rev. 197, 205 (1994) [hereinafter Koppelman, Sex Discrimination]. 
status and its concomitant rights and benefits on the basis of the applicants' sex. As such, [the statute] establishes a sex-based classification." 55

But the Baehr plurality is not alone in reaching this conclusion. ${ }^{56}$ Five years later, an Alaska Superior Court judge put the point this way in recognizing same-sex couples' right to marry:

That this is a sex-based classification can readily be demonstrated: if twins, one male and one female, both wished to marry a woman and otherwise met all of the Code's requirements, only gender prevents the twin sister from marrying under the present law. Sex-based classification can hardly be more obvious. ${ }^{57}$

55. Baehr, 852 P.2d at 64 (citation omitted). The court described another court's earlier rejection of this argument as an "exercise in tortured and conclusory sophistry." Id. at 63. In the academic literature, Edward Stein has set out this argument in some detail, though he ultimately rejects it. See Stein, supra note 38 , at 506-15.

56. Although the focus here is on the presence of the sex-discrimination argument in marriage cases, it bears noting that the argument has been embraced in other contexts within the United States and in jurisdictions elsewhere as well. For example, within the United States, in dissent from a state appellate ruling upholding Texas's "homosexual conduct" law (later reversed by the Supreme Court in Lawrence $v$. Texas), one judge offered this scenario to highlight sex discrimination in a law that singularly burdened same-sex couples:

There are three people in a room: Alice, Bob, and Cathy. Bob approaches Alice, and with her consent, engages with her in several varieties of "deviate sexual intercourse," the conduct at issue here. Bob then leaves the room. Cathy approaches Alice, and with her consent, engages with her in several kinds of "deviate sexual intercourse." Cathy is promptly arrested for violating [the statute].

Lawrence v. State, 41 S.W.3d 349, 368 (Tex. App. 2001) (Anderson, J., dissenting), rev'd, 539 U.S. 558 (2003).

The judge explained that he "indulged in this tableau to demonstrate one important point: one person simply committed a sex act while another committed a crime. While the acts were exactly the same, the gender of the actors was different, and it was this difference alone that determined the criminal nature of the conduct." Id.; see also, e.g., Heller v. Edgewater Country Club, 195 F. Supp. 2d 1212, 1224, 1227 (D. Or. 2002) (finding sex discrimination when an employer fired a lesbian employee because of her relationship with a woman because no termination would have occurred if employee had a relationship with a man); U.N. Human Rights Comm., Toonen v. Australia, Comm. No. 488/1992, II 8.1-12, U.N. Doc. CCPR/C/50/D.488/1992 (1994), available at http://www.ohchr.org/ Documents/Publications/SDecisionsVol5en.pdf (on file with the Columbia Law Review) (deciding that the sex-discrimination prohibition of the International Covenant on Civil and Political Rights encompassed sexual-orientation discrimination and striking down Tasmanian laws that criminalized sexual contact between men). But see Case C-249/96, Grant v. South-West Trains Ltd., 1998 E.C.R. I-621 (rejecting sex-discrimination challenge to a law that authorized employment benefits to married employees but not to employees with nonmarital same-sex partners because, in the court's view, the law treated men and women equally).

57. Brause v. Bureau of Vital Statistics, No. 3AN-95-6562 CI, 1998 WL 88743, at *6 (Alaska Super. Ct. Feb. 27, 1998). The decision was stayed, and Alaska voters later amended their state constitution to bar marriage rights for same-sex couples. See Alaska Const. art. I, §25 ("To be valid or recognized in this State, a marriage may exist only between one man and one woman."). 
Better known is Justice Denise Johnson's opinion in the Vermont Supreme Court, where she concluded, regarding Vermont's different-sex marriage requirement, that "this is a straightforward case of sex discrimination." ${ }^{58}$ Like the Alaska judge, Justice Johnson offered an illustration:

[C] onsider the following example. Dr. A and Dr. B both want to marry Ms. C, an X-ray technician. Dr. A may do so because Dr. A is a man. Dr. B may not because Dr. B is a woman. Dr. A and Dr. $B$ are people of opposite sexes who are similarly situated in the sense that they both want to marry a person of their choice. The statute disqualifies Dr. B from marriage solely on the basis of her sex and treats her differently from Dr. A, a man. ${ }^{59}$

"This," she added, "is sex discrimination." 60

Also in the earlier years of marriage litigation, a justice of the Massachusetts Supreme Judicial Court, concurring in that court's 2003 Goodridge v. Department of Public Health decision to allow marriage for same-sex couples, declared it "self-evident" that denying those couples marriage constituted sex discrimination because under the different-sex eligibility requirement, "an individual's choice of marital partner is constrained because of his or her own sex." 61 Across the country, a Washington Supreme Court justice dissented from the majority's denial of marriage rights with this observation in connection with the state's Equal Rights Amendment: “[The state's] DOMA violates the ERA because it discriminates on the basis of sex. A woman cannot marry the woman of her choice but a man can marry the woman of his choice." 62

More recently, in what might be called the second wave of same-sex couples' marriage cases to engage with the sex-discrimination argument, ${ }^{63}$ a federal district court made the same point regarding the

58. Baker v. State, 744 A.2d 864, 905 (Vt. 1999) (Johnson, J., concurring in part and dissenting in part).

59. Id. at 906 .

60. Id. Chief Judge Judith Kaye of the New York Court of Appeals wrote similarly: "Under the Domestic Relations Law, a woman who seeks to marry another woman is prevented from doing so on account of her sex-that is, because she is not a man. If she were, she would be given a marriage license to marry that woman." Hernandez v. Robles, 855 N.E.2d 1, 29 (N.Y. 2006) (Kaye, C.J., dissenting). A midlevel appellate judge in the same case took the same position: " $[\mathrm{T}]$ he discrimination caused by the challenged statutes here, on the basis of the parties' sexual orientation, properly falls within the broader category of gender discrimination. To illustrate, a woman who seeks to marry another woman is denied that right because she is not a man." Hernandez v. Robles, 805 N.Y.S.2d 354, 385 (App. Div. 2005) (Saxe, J., dissenting) (citation omitted), aff'd, 855 N.E.2d 1.

61. 798 N.E.2d 941, 971 (Mass. 2003) (Greaney, J., concurring).

62. Andersen v. King Cnty., 138 P.3d 963, 1037 (Wash. 2006) (Bridge, J., dissenting).

63. One can reasonably debate both how many waves best characterize same-sex couples' marriage cases and what the start and end point of each wave might be. Cf. Eskridge, Backlash Politics, supra note 53, at 281 (discussing the progression of marriage cases). For purposes of thinking about the sex-discrimination argument's reception, even though its limited uptake by judges has been fairly steady since Baehr v. Lewin, 852 P.2d 44 (Haw. 1993), through the present, it seems useful to think about the cases in three 
federal DOMA: "Ms. Golinski is prohibited from marrying . . . a woman, because [she] is a woman .... Thus, DOMA operates to restrict Ms. Golinski's access to federal benefits because of her sex." ${ }^{64}$ In Perry, Chief Judge Vaughn Walker engaged the point as well but went further to spell out the connection between sex and sexual-orientation discrimination: "[S]ex and sexual orientation are necessarily interrelated, as an individual's choice of romantic or intimate partner based on sex is a large part of what defines an individual's sexual orientation." 65

basic groups: 1) from the time of Baehr, in which the marriage-equality claim received its first recognition from an appellate court, through the Vermont Supreme Court ruling that required equal benefits, but not marriage, for same-sex couples; 2) from Goodridge v. Department of Public Health, 798 N.E.2d 941 (Mass. 2003), as the first ruling to insist on marriage for same-sex couples to the Supreme Court ruling invalidating DOMA in United States v. Windsor, 133 S. Ct. 2675 (2013); and 3) the post-Windsor challenges to states' denial of marriage rights and recognition to same-sex couples, which are ongoing at the time of publication. Of course, as noted earlier, marriage litigation preceded Baehr as well, but litigants in those early cases met with no success in court, see supra note 53, so those cases are less relevant here.

In the first wave, the sex-discrimination argument received prominent, if limited, endorsement as some judges began tentative forays toward marriage equality. In the second wave, which saw a mix of victories and losses for same-sex couples seeking marriage rights, courts' engagement with the argument continued, though also in a limited way. In this phase, no one argument had taken hold, suggesting that there was special value in testing the sex-discrimination argument's viability along with other equality and fundamental rights arguments. In the present third wave, the antitargeting argument has already received Supreme Court endorsement, raising the question whether and how including a sex-discrimination argument adds value for advocates and decisionmakers. For an extended analysis of the earliest marriage cases, see, e.g., William N. Eskridge, Jr., A History of Same-Sex Marriage, 79 Va. L. Rev. 1419, 1427-30 (1993) [hereinafter Eskridge, A History]; see also Scott Barclay \& Shauna Fisher, Cause Lawyers in the First Wave of Same Sex Marriage Litigation, in Cause Lawyers and Social Movements 84, 84-87, 88-89 (Austin Sarat \& Stuart A. Scheingold eds., 2006). For an in-depth analysis of advocacy strategies situated in the context of the California marriage cases, see generally Scott L. Cummings \& Douglas NeJaime, Lawyering for Marriage Equality, 57 UCLA L. Rev. 1235 (2010).

64. Golinksi v. U.S. Office of Pers. Mgmt., 824 F. Supp. 2d 968, 982 n.4 (N.D. Cal. 2012), appeal dismissed per stipulation, 724 F.3d 1048 (9th Cir. 2013). The court had little difficulty finding that sex and sexual-orientation discrimination could coexist: "But DOMA also operates to restrict Ms. Golinski's access to federal benefits because of her sexual orientation; her desire to marry another woman arises only because she is a lesbian. Accordingly, the Court addresses the Equal Protection challenge on the basis of sexual orientation." Id.

65. Perry v. Schwarzenegger, 704 F. Supp. 2d 921, 996 (N.D. Cal. 2010), aff'd sub nom. Perry v. Brown, 671 F.3d 1052 (9th Cir. 2012), vacated and remanded sub nom. Hollingsworth v. Perry, 133 S. Ct. 2652 (2013). Judge Walker also embraced the facialdiscrimination argument. See id. ("Here, for example, Perry is prohibited from marrying Stier, a woman, because Perry is a woman. If Perry were a man, Proposition 8 would not prohibit the marriage. Thus, Proposition 8 operates to restrict Perry's choice of marital partner because of her sex."). Based on the interrelation between sex and sexual orientation, Judge Walker continued: "Having considered . . the fact that Proposition 8 eliminates a right only a gay man or a lesbian would exercise, the court determines that 
Following Windsor's invalidation of DOMA, the sex-discrimination argument again met with judicial approval. In holding Utah's marriage ban unconstitutional, a federal district court there found that the exclusion of same-sex couples from marriage constituted sex discrimination. Addressing a counterargument advanced by the state, the court wrote: " $[\mathrm{T}]$ he fact of equal application to both men and women does not immunize [the state's law] from the heightened burden" that equalprotection jurisprudence imposes on sex-based classifications. ${ }^{66}$ Years earlier, New York's then-chief judge, Judith Kaye, made the same point in response to the argument that sex discrimination was not present because the eligibility requirement applied to both men and women. She wrote: "That the statutory scheme applies equally to both sexes does not alter the conclusion that the classification here is based on sex." ${ }^{67}$ In Vermont, Justice Johnson also pointedly rejected the equal-application theory embraced by the majority as a reason to reject the sexdiscrimination argument: "Under the State's analysis, a statute that required courts to give custody of male children to fathers and female children to mothers would not be sex discrimination. Although such a law would not treat men and women differently, I believe it would discriminate on the basis of sex." 68

In the most extensive development of the sex-discrimination argument to date, Justice Berzon of the Ninth Circuit elaborated both the facial-discrimination and stereotyping arguments while concurring in the

plaintiffs' equal protection claim is based on sexual orientation, but this claim is equivalent to a claim of discrimination based on sex." Id. (emphasis added).

66. Kitchen v. Herbert, 961 F. Supp. 2d 1181, 1206 (D. Utah 2013), aff'd, 755 F.3d 1193 (10th Cir.), cert. denied, No. 14-124, 2014 WL 3841263 (U.S. Oct. 6, 2014). At the same time, however, the court did not apply heightened scrutiny to the marriage law because it found that the measure failed rational-basis review. Id. at 1206-07. On appeal, the Tenth Circuit addressed the sex-discrimination claim at oral argument but did not engage with it in its opinion. Oral Argument at 3:55, Kitchen, 755 F.3d 1193 (No. 13-4178), available at https://www.ca10.uscourts.gov/clerk/news/oral-argument-audio-recording-13 -4178-kitchen-v-herbert (on file with the Columbia Law Review) ("You have a man who wants to marry another man. The only thing that bars him from getting married is sexgender.... Why shouldn't this be a situation of ... evaluating the gender for intermediate scrutiny?”).

67. Hernandez v. Robles, 855 N.E.2d 1, 29 (N.Y. 2006) (Kaye, C.J., dissenting). Here, Chief Judge Kaye is responding to the position, taken by the majority in Hernandez and by others elsewhere, that Loving's rejection of a similar "equal application" argument does not apply to exclusions of same-sex couples from marriage because antimiscegenation laws sought to privilege whites whereas the different-sex marriage rule does not similarly privilege one sex over the other. See id. at 11 (distinguishing Loving, which "was in substance anti-black legislation," and stating that "[p]laintiffs do not argue here that the legislation they challenge is designed to subordinate either men to women or women to men as a class"); see also supra Part I.B (discussing sex-stereotyping argument).

68. Baker v. State, 744 A.2d 864, 906 n.10 (Vt. 1999) (Johnson, J., concurring in part and dissenting in part). 
Ninth Circuit's invalidation of marriage bans in Idaho and Nevada. ${ }^{69}$ In addition to making the basic facial-discrimination argument in ways already described ${ }^{70}$ Judge Berzon offered an extended rejection of the equal-application theory, observing that, consistent with several decades of case law, "it is simply irrelevant that the same-sex marriage prohibitions privilege neither gender on the whole or on average" because the bans "strip individuals of their rights... solely on the basis of the individuals' gender." 71

\section{B. The Limited Uptake of Sex Stereotyping}

Although the stereotype-focused sex-discrimination theory has not received nearly as much attention (or graphic depiction) from courts as the formal-equality argument, it has received enough positive mention by adjudicators to warrant our attention here. Justice Johnson of the Vermont Supreme Court embraced the argument forthrightly, explaining that the "sex-based classification contained in the marriage laws is unrelated to any valid purpose, but rather is a vestige of sex-role stereotyping that applies to both men and women."72 Elaborating, Justice Johnson wrote that the state's asserted purpose of "uniting men and women to celebrate the 'complementarity' ... of the sexes and providing male and female role models for children" rested on "broad and vague generalizations about the roles of men and women that reflect outdated sex-role stereotyping." 73

Justice John Greaney of the Massachusetts Supreme Judicial Court made the same connection in his Goodridge concurrence, noting the operation of "ingrained assumptions with respect to historically accepted roles of men and women within the institution of marriage." 74 And while the Goodridge majority opinion did not take up the sex-discrimination argument directly, ${ }^{75}$ it did recognize the sex stereotypes embedded in

69. Latta v. Otter, Nos. 14-35420, 14-35421, 12-17668, 2014 WL 4977682, at*14-*29 (9th Cir. Oct. 7, 2014) (Berzon, J., concurring).

70. See, e.g., id. at *14 ("Only women may marry men, and only men may marry women."); id. ("A law that facially dictates that a man may do X while a woman may not, or vice versa, constitutes, without more, a gender classification.”).

71. Id. at $* 17$. Judge Berzon also explained that facial sex discrimination exists because "the same-sex marriage laws treat the subgroup of men who wish to marry men less favorably than the otherwise similarly situated subgroup of women who want to marry men" and vice versa. Id. ("[A] classification that affects only some members of one gender is still sex discrimination if similarly situated members of the other gender are not treated the same way.").

72. Baker, 744 A.2d at 906 (Johnson, J., concurring in part and dissenting in part).

73. Id. at 909.

74. Goodridge v. Dep't of Pub. Health, 798 N.E.2d 941, 973 (Mass. 2003) (Greaney, J., concurring).

75. See id. at 961 (majority opinion) (applying rational-basis review rather than heightened scrutiny required for sex-based classifications). The Ninth Circuit also did not take up the sex-discrimination argument directly in Latta, but the court signaled possible 
one of the justifications proffered for excluding same-sex couples from marriage. Rejecting the dissent's position that mother-father pairs are optimal for child rearing on the ground that it rested on "stereotypical premises," the Court wrote: "That analysis hews perilously close to the argument, long repudiated by the Legislature and the courts, that men and women are so innately and fundamentally different that their respective 'proper spheres' can be rigidly and universally delineated." 76

Judge Berzon, concurring in the Idaho and Nevada marriage cases, elaborated these themes and analyzed the states' gendered justifications

endorsement with its observation that "the constitutional restraints... on sex-role stereotyping . . . may provide another potentially persuasive answer to defendants' theory." Latta, 2014 WL 4977682, at *9. The court also noted that "defendants have offered no probative evidence in support of their [gender] 'complementarity' argument." Id.

76. Goodridge, 798 N.E.2d at 965 n.28. Interestingly, in other contexts, courts have been more open to the argument that this sort of stereotyping falls squarely within sexdiscrimination prohibitions. Especially in employment cases, numerous courts have held that employers-both public and private-may not require their employees to conform to sex-role stereotypes. Even in 1989, the Supreme Court expressed no ambivalence on this point in applying Title VII of the Civil Rights Act of 1964, 42 U.S.C. $§ 2000$ e (2012), to a sex-stereotyping claim: "[W]e are beyond the day when an employer could evaluate employees by assuming or insisting that they matched the stereotype associated with their group ...." Price Waterhouse v. Hopkins, 490 U.S. 228, 251 (1989). For further discussion of the sex-discrimination argument's success in this arena, see generally Mary Anne Case, Legal Protections for the "Personal Best" of Each Employee: Title VII's Prohibition on Sex Discrimination, the Legacy of Price Waterhouse v. Hopkins, and the Prospect of ENDA, 66 Stan. L. Rev. 1333, 1338-61 (2014) (discussing the impact of Price Waterhouse and noting in its wake an "increasing trend of the lower courts to protect sexual minorities under the text of Title VII").

Since that time, numerous circuit courts have applied similar reasoning to reject employer demands for sex-role conformity, including in connection with harassment of and discrimination against gay and transgender employees. See, e.g., Glenn v. Brumby, 663 F.3d 1312, 1320-21 (11th Cir. 2011) (holding discrimination based on gender nonconformity constitutes sex discrimination under the Equal Protection Clause, and finding employer's decision to fire plaintiff based on "sheer fact of his transition" from male to female impermissible); Smith v. City of Salem, 378 F.3d 566, 571-72 (6th Cir. 2004) (concluding fire department impermissibly suspended transsexual firefighter for "his failure to conform to sex stereotypes by expressing less masculine, and more feminine mannerisms and appearance"); Rene v. MGM Grand Hotel, Inc., 305 F.3d 1061, 1067 (9th Cir. 2002) (en banc) (finding it "clear" that sexualized attacks on gay employee stated sexdiscrimination claim under Title VII); Nichols v. Azteca Rest. Enters., 256 F.3d 864, 875 (9th Cir. 2001) (holding harassment of gay waiter because of his effeminate mannerisms constituted sex discrimination under Title VII).

Likewise, the Equal Employment Opportunity Commission (EEOC) has rejected employer demands for sex conformity from lesbian, gay, bisexual, and transgender employees. See Macy v. Holder, EEOC Appeal No. 0120120821 (Apr. 20, 2012), available at http:/ / www.eeoc.gov/decisions/0120120821\%20Macy\%20v\%20DOJ\%20ATF.txt (on file with the Columbia Law Review) (holding discrimination based on gender identity constitutes discrimination because of sex under Title VII); Veretto v. Donahoe, EEOC Appeal No. 0120110873, 2011 WL 2663401, at *3 (July 1, 2011) (stating that discrimination against individual based on marriage to a same-sex spouse can give rise to sex-stereotyping claim under Title VII). 
amid several decades of sex-stereotyping case law. ${ }^{77}$ She also highlighted chronological changes in civil marriage from enforced inequality between male and female spouses to today, when "a combination of constitutional sex-discrimination adjudication, legislative changes, and social and cultural transformation has, in a sense, already rendered contemporary marriage "'genderless," to use the phrase favored by the defendants."78 Against that backdrop, Judge Berzon concluded that "[t]he same sex marriage prohibitions seek to preserve an outmoded, sex-role-based vision of the marriage institution." 79

Although my primary interest here concerns judicial receptivity to the sex-discrimination argument, it bears noting that both versions of the argument have academic support as well. ${ }^{80}$ Relatively few legal scholars spend time elaborating the facial-discrimination argument because it is so straightforward, ${ }^{81}$ but many have focused on showing how govern-

77. Latta, 2014 WL 4977682, at *18-*29 (Berzon, J., concurring). Judge Berzon described the states' claims:

The defendants, for example, assert that "gender diversity or complementarity among parents ... provides important benefits" to children, because "mothers and fathers tend on average to parent differently and thus make unique contributions to the child's overall development." The defendants similarly assert that "[t]he man-woman meaning at the core of the marriage institution, reinforced by the law, has always recognized, valorized, and made normative the roles of 'mother' and 'father' and their uniting, complementary roles in raising their offspring."

Id. at *19 (alterations in original). She then wrote:

Viewed through the prism of the Supreme Court's contemporary antistereotyping sex discrimination doctrine, these proffered justifications simply underscore that the same-sex marriage prohibitions discriminate on the basis of sex, not only in their form-which, as I have said, is sufficient in itself-but also in reviving the very infirmities that led the Supreme Court to adopt an intermediate scrutiny standard for sex classifications in the first place.

Id.

78. Id. at $* 23$.

79. Id. at $* 20$; see also id. at $* 23$ (describing " "the sex-based classification contained in the[se] marriage laws'" as, "at best, 'a vestige of sex-role stereotyping' that long plagued marital regimes before the modern era... and, at worst, an attempt to reintroduce gender roles" (alteration in original) (quoting Baker v. State, 744 A.2d 864, 906 (Vt. 1999) (Johnson, J., concurring in part and dissenting in part))).

80. See, e.g., Case, What Feminists Have to Lose, supra note 32, at 1213-27 (discussing formal-equality and sex-stereotyping theories). See generally supra notes 32-33 (discussing additional scholarship related to both sex-discrimination theories).

81. But see, e.g., William N. Eskridge, Jr., Sexual and Gender Variation in American Public Law: From Malignant to Benign to Productive, 57 UCLA L. Rev. 1333, 1352 (2010) (describing exclusion of same-sex couples from marriage as "last major state sexual orientation discrimination-and one of the last sex discriminations-to be revoked"); Andrew Koppelman, Response: Sexual Disorientation, 100 Geo. L.J. 1083, 1087 (2012) ("[California's registrars] are not instructed to ask ... whom you have had sex with in the past[] or how you self-identify because the discriminatory law ... does not classify on any of those bases.... [They ask] whether the couple includes one male and one female."); see also William N. Eskridge, Jr., The Case for Same-Sex Marriage 152-82 (1996) (contending that the facial-discrimination argument can be applied to "require the state 
mental maintenance of the sex-based eligibility rule depends on and perpetuates sex stereotypes. ${ }^{82}$ As Sylvia Law explained in a landmark 1988 article, " $[\mathrm{C}]$ ontemporary legal and cultural contempt for lesbian women and gay men serves primarily to preserve and reinforce the social meaning attached to gender." "s3 Andrew Koppelman has likewise written extensively on the point that "discrimination against gays is a kind of sex discrimination," explaining that "sexism is an important wellspring of antigay animus and the homosexuality taboo functions to strengthen gender hierarchy." 84

\section{WHY SO LITTLE TRACTION FOR THE SEX-DiSCRIMINATION ARGUMENT IN MARRIAGE CASES?}

Although the opinions just discussed were unequivocal that malefemale marriage eligibility and recognition requirements discriminate based on sex, these are but a handful of opinions in a much larger universe..$^{85}$

The argument that is so clearly right to its proponents ${ }^{86}$ turns out to be either wrong or unworthy of engagement in the view of nearly every

to justify its discriminatory sex-based classification statutes prohibiting same-sex marriage"); Koppelman, Sex Discrimination, supra note 54, at 201-14 (describing and defending the facial-discrimination argument).

82. See, e.g., Case, What Feminists Have to Lose, supra note 32, at 1216-27 (discussing development of sex-stereotyping jurisprudence); Widiss et al., supra note 32, at 479-87 (discussing sex stereotyping within government rationales for marriage bans).

83. Sylvia A. Law, Homosexuality and the Social Meaning of Gender, 1988 Wis. L. Rev. 187, 187. That year, Suzanne Pharr published her pathbreaking book-length treatment of the ways in which hostility toward lesbians and gay men is used to maintain sex roles. See Suzanne Pharr, Homophobia: A Weapon of Sexism (1988) (developing links between sexism and hostility toward lesbians and gay men).

84. Andrew Koppelman, DOMA, Romer, and Rationality, 58 Drake L. Rev. 923, 94648 (2010) [hereinafter Koppelman, DOMA, Romer, and Rationality]; see also Koppelman, Sex Discrimination, supra note 54, at 234-57 ("Laws that discriminate against gays are the product of a political decisionmaking process that is biased by sexism. They implicitly stigmatize women, and they reinforce the hierarchy of men over women.").

85. Indeed, not one is a controlling appellate opinion. As a federal district court in Wisconsin recently wrote, after describing the Hawaii Supreme Court's sex-discrimination analysis, "Since then, however, the sex discrimination theory has been rejected by most courts to consider it, even those ruling in favor of the plaintiffs on other grounds." Wolf $\mathrm{v}$. Walker, 986 F. Supp. 2d 982, 1008 (W.D. Wis.), aff'd sub nom. Baskin v. Bogan, 766 F.3d 648 (7th Cir.), cert. denied, No. 14-278, 2014 WL 4425163 (U.S. Oct. 6, 2014). A federal district court in Hawaii observed similarly that "[t] he vast majority of courts considering the issue [have concluded] that an opposite-sex definition of marriage does not constitute gender discrimination." Jackson v. Abercrombie, 884 F. Supp. 2d 1065, 1098 (D. Haw. 2012), vacated as moot, No. 12-16995, 2014 WL 5088199 (9th Cir. Oct. 10, 2014).

86. In her concurring opinion in the Idaho and Nevada marriage cases, Judge Berzon repeatedly characterized the sex-discrimination argument as "obvious." See, e.g., Latta v. Otter, No. 14-35420, 2014 WL 4977682, at*15 (9th Cir. Oct. 7, 2014) (Berzon, J., concurring) (stating that "same-sex marriage prohibitions today [are] quite obviously about gender"); id. at*19 (observing that "obviously, the gender stereotyping at the core 
other judge to whom it has been presented. While this is not surprising among judges who reject same-sex couples' claims, the same is true for most of the judges who find in favor of marriage equality as well. I focus on those judges' analysis here to set the foundation for the "risky argument" discussion that will follow.

\section{A. The Judicial Perspective}

Preliminarily, it bears noting that most courts sidestep the sexdiscrimination argument entirely. Indeed, of the many opinions striking down marriage discrimination against same-sex couples in the first year following the Windsor ruling, only six engaged in any analysis of it, and only two accepted it. ${ }^{87}$

Courts that favor marriage equality but reject the sex-discrimination argument tend to follow two basic lines of reasoning. First, many dismiss the formal-equality argument on the ground that the rule applies equally to both men and women. ${ }^{8}$ Second, many reject the stereotyping theory on the ground that the exclusion of same-sex couples from marriage was not intended to perpetuate sex stereotypes or the subordination of women to men, unlike, for example, the "equal application" antimiscegenation law in Loving that the Supreme Court found was "designed to maintain White Supremacy." 89

On the first, the Vermont Supreme Court, for example, flatly rejected the sex-discrimination argument even while finding that Vermont's refusal to recognize same-sex couples' relationships violated

of the same-sex marriage prohibitions clarifies that those laws affect men and women in basically the same way as ... a wide range of laws and policies that have been viewed consistently as discrimination based on sex").

87. For discussion of decisions rejecting the sex-discrimination argument, see infra notes 103-108 and accompanying text (discussing Idaho, New Mexico, Oklahoma, Oregon, and Wisconsin opinions). For opinions accepting the argument, see supra notes 66, 69-71 and accompanying text (discussing Kitchen v. Herbert and Latta v. Otter, respectively). Other courts during the first year following Windsor invalidated or preliminarily enjoined laws restricting same-sex couples' marriage rights only on the sexual-orientation-discrimination and/or fundamental-rights claims. See, e.g., Whitewood v. Wolf, 992 F. Supp. 2d 410, 423-24, 431 (M.D. Pa. 2014); Baskin v. Bogan, 983 F. Supp. 2d 1021, 1026-27, 1029 (S.D. Ind. 2014), aff'd, 766 F.3d 648 , cert. denied, 2014 WL 4425162; Henry v. Himes, No. 1:14-CV-129, 2014 WL 1418395, at*18 (S.D. Ohio Apr. 14, 2014); Tanco v. Haslam, 7 F. Supp. 3d 759, 769, 771-72 (M.D. Tenn.), rev'd sub nom. DeBoer v. Snyder, No. 14-1341, 2014 WL 5748990 (6th Cir. Nov. 6, 2014), available at http:/ /sblog.s3.amazonaws.com/wp-content/uploads/2014/11/6th-CA-marriage-ruling11-6-14.pdf (on file with the Columbia Law Review); De Leon v. Perry, 975 F. Supp. 2d 632, 639 (W.D. Tex. 2014); Lee v. Orr, No. 13-CV-8719, 2014 WL 683680, at *2 (N.D. Ill. Feb. 21, 2014); Bourke v. Beshear, 996 F. Supp. 2d 542, 547, 556-57 (W.D. Ky.), rev'd sub nom. DeBoer, 2014 WL 5748990; Wright v. Arkansas, No. 60CV-13-2662, 2014 WL 1908815, at*6, *8 (Cir. Ct. Ark. May 9, 2014); Griego v. Oliver, 316 P.3d 865, 871, 889 (N.M. 2013).

88. See, e.g., Goodridge v. Dep't of Pub. Health, 798 N.E.2d 941, 991-92 (Mass. 2003); Baker v. State, 744 A.2d 864, 880 n.13 (Vt. 1999).

89. Loving v. Virginia, 388 U.S. 1, 11 (1967). 
the state constitution. ${ }^{90}$ "Here, there is no discrete class subject to differential treatment solely on the basis of sex; each sex is equally prohibited from precisely the same conduct," the court wrote. ${ }^{91}$ The Massachusetts high court in Goodridge reached the same conclusion: "The Massachusetts marriage statute does not subject men to different treatment from women; each is equally prohibited from precisely the same conduct." 92

Defenders of the formal-equality argument typically respond by invoking Loving's point that "[t] he mere fact of equal application" does not render a classifying law constitutional. ${ }^{93}$ In Baehr v. Lewin, for example, the Hawaii Supreme Court plurality relied on Loving's "reject[ion of] the notion that the mere 'equal application' of a statute containing racial classifications is enough to remove the classifications from the Fourteenth Amendment's proscriptions of all invidious discriminations." 94 The Hawaii court added: "Substitution of 'sex' for 'race' and [the Hawaii Constitution's Equal Rights Amendment] for the fourteenth amendment yields the precise case before us together with the conclusion that we have reached." ${ }^{55}$ Likewise, as Chief Judge Kaye wrote in New York, “The 'equal application' approach to equal protection analysis was expressly rejected by the Supreme Court in Loving. . .."96

But, for many, this observation is inapplicable because, in their view, the different-sex eligibility rule does not rest on sex stereotypes in the way that Virginia's law rested on racial hostility. As the New York Court of Appeals majority wrote, over Chief Judge Kaye's dissent:

90. Baker, 744 A.2d at 886 (holding exclusion of same-sex couples from marriage violated state constitution's Common Benefits Clause).

91. Id. at 880 n.13. The court also found that "most appellate courts that have addressed the issue have rejected the claim that defining marriage as the union of one man and one woman discriminates on the basis of sex." Id.

92. 798 N.E.2d at 991. Numerous courts that rejected marriage-equality claims also took this position. See, e.g., Conaway v. Deane, 932 A.2d 571, 598 (Md. 2007) (stating that "it stretch[es] the concept of gender discrimination to assert that [the marriage statute] applies to treatment of same-sex couples differently from opposite-sex couples" (alterations in original) (quoting Dean v. District of Columbia, 653 A.2d 307, 363 n.2 (D.C. 1995) (Steadman, J., concurring)) (internal quotation marks omitted)); Hernandez v. Robles, 855 N.E.2d 1, 10-11 (N.Y. 2006) ("By limiting marriage to opposite-sex couples, New York is not engaging in sex discrimination ... . Women and men are treated alikethey are permitted to marry people of the opposite sex, but not people of their own sex."); Andersen v. King Cnty., 138 P.3d 963, 989 (Wash. 2006) (holding state marriage restriction "does not draw any classifications based on sex" because "[i]t does not render benefits to just one sex, nor does it restrict or deny rights of one sex").

93. 388 U.S. at 8.

94. 852 P.2d 44, 68 (Haw. 1993) (quoting Loving, 388 U.S. at 8) (internal quotation marks omitted).

95. Id.

96. Hernandez, 855 N.E.2d at 29 (Kaye, C.J., dissenting); see also supra notes 69-71 and accompanying text (discussing Judge Berzon's rejection of the equal-application argument). 
This is not the kind of sham equality that the Supreme Court confronted in Loving; the statute there, prohibiting black and white people from marrying each other, was in substance antiblack legislation. Plaintiffs do not argue here that the legislation they challenge is designed to subordinate either men to women or women to men as a class. ${ }^{97}$

Similarly, as the Vermont Supreme Court majority stated:

It is one thing to show that long-repealed marriage statutes subordinated women to men within the marital relation. It is quite another to demonstrate that the authors of the marriage laws excluded same-sex couples because of incorrect and discriminatory assumptions about gender roles or anxiety about gender-role confusion. That evidence is not before us. ${ }^{98}$

Against that backdrop, the Vermont court indicated that it was "not persuaded that sex discrimination offers a useful analytic framework for determining" the plaintiff couples' rights. ${ }^{99}$ By implication, the Massachusetts Supreme Judicial Court can be seen to have adopted the same reasoning, finding that the state equal-rights amendment was inapplicable to the different-sex marriage rule because the amendment was intended to "prohibit laws that advantage one sex at the expense of the other." 100

In the California Supreme Court's 2008 ruling granting marriage rights, which was functionally overturned by Proposition 8's restriction on marriage for same-sex couples, Chief Justice George went on at length to reject the sex-discrimination argument on all of these grounds. Relying on numerous earlier cases, he wrote that, "in realistic terms, a statute

97. Hernandez, 855 N.E.2d at 11.

98. Baker v. State, 744 A.2d 864, 880 n.13 (Vt. 1999).

99. Id. at 880 n.13. But Justice Johnson, in her concurrence, suggested that the majority had missed her point:

I do not contend, as the majority suggests, that the real purpose of the

exclusion of same-sex partners from the marriage laws was to maintain

certain male and female stereotypes .... I agree that the original purpose

was very likely not intentionally discriminatory toward same-sex couples.

The question is whether the State may maintain a classification today only

by giving credence to generally discredited sex-role stereotyping.

Id. at 906 n.11 (Johnson, J., concurring).

100. Goodridge v. Dep't of Pub. Health, 798 N.E.2d 941, 991 (Mass. 2003). Alternately, this part of the Goodridge opinion can be read as rejecting the formal-equality argument, which would mean that the Goodridge majority opted not to engage with the substantive-equality argument at all, even though that argument was proffered by the concurrence.

Judges who oppose marriage equality tend to maintain Loving's inapplicability even more vigorously. As a Connecticut Supreme Court justice who dissented from the majority's decision to recognize marriage rights wrote, "The two cases are in no way similar." Kerrigan v. Comm'r of Pub. Health, 957 A.2d 407, 503 n.26 (Conn. 2009) (Borden, J., dissenting). Allowing same-sex couples to marry, he wrote, would alter the nature of marriage by threatening the "survival of the human race" in a way that allowing interracial couples to marry would not. Id. 
or policy that treats same-sex couples differently from opposite sex couples... does not treat an individual man or an individual woman differently because of his or her gender but rather accords differential treatment because of the individual's sexual orientation." 101 If courts were to find "illegitimate gender-related stereotyping based on the view that men are attracted to women and women are attracted to men," then sexualorientation discrimination "always would constitute a subset of discrimination on the basis of sex," he added. ${ }^{102}$

Following Windsor, a couple of other courts also went out of their way to reject the sex-discrimination argument while still striking down the challenged marriage bans. In Oklahoma, for example, a federal district court echoed the observation of some others just mentioned that the exclusion of same-sex couples from marriage "does not place any disproportionate burdens on men and women, and does not draw upon stereotypes applicable only to male or female couples." ${ }^{103}$ Most significantly, though, the court doubted that sex discrimination (or at least its view of sex discrimination) had motivated the law's enactment: "Common sense dictates that the intentional discrimination occurring in this case has nothing to do with gender-based prejudice or stereotypes . ..." 104 Similarly, a federal district court in Oregon concluded that " $[\mathrm{t}]$ he targeted group here is neither males nor females, but homosexual males and homosexual females. Therefore, I conclude the state's marriage laws discriminate on the basis of sexual orientation, not gender." 105

The New Mexico Supreme Court, which found the equal-application point persuasive in its rejection of the sex-discrimination argument, also stressed that its own sex-discrimination case law "has been gender-based, scrutinizing the historical discrimination against women." 106 Interestingly, a district court in Idaho, while also rejecting the sex-discrimination argument on similar grounds, recognized nonetheless that "[a] person's gender and sexual orientation are two sides of the same coin," 107 and invoked the district court's observation in Perry v. Schwarzenegger that "sex and sexual orientation are necessarily interrelated, as an individual's

101. In re Marriage Cases, 183 P.3d 384, 437 (Cal. 2008).

102. Id. at 439.

103. Bishop v. United States ex rel. Holder, 962 F. Supp. 2d 1252, 1286 (N.D. Okla. 2014).

104. Id.

105. Geiger v. Kitzhaber, 994 F. Supp. 2d 1128, 1140 (D. Or. 2014).

106. Griego v. Oliver, 316 P.3d 865, 880 (N.M. 2013).

107. Latta v. Otter, No. 1:13-cv-00482-CWD, 2014 WL 1909999, at*15 (D. Idaho May 13) (" $[\mathrm{T}]$ wo men have no more right to marry under Idaho law than two women. In other words, Idaho's Marriage Laws are facially gender neutral and there is no evidence that they were motivated by a gender discriminatory purpose."), aff'd, No. 14-35420, 2014 WL 4977682 (9th Cir. Oct. 7, 2014). 
choice of romantic or intimate partner based on sex is a large part of what defines an individual's sexual orientation." 108

\section{B. Theoretical Concerns}

Scholarly skepticism toward the sex-discrimination argument as a means for challenging antigay discrimination overlaps somewhat with the case law that rejects the argument in the marriage context. Both reject the formal-equality analysis as inadequate and superficial; both maintain, too, that a state interest in sex stereotyping does not persuasively explain why governments maintain laws and policies that have the primary purpose and effect of burdening gay people. ${ }^{109}$ Still, to round out consideration of the possible reasons for the sex-discrimination argument's minimal traction, I consider several of the leading theoretical objections to the argument.

Among the argument's most prominent critics is Edward Stein, whose position is that the argument is "sociologically, theoretically, and morally flawed." ${ }^{110}$ In particular, Stein has contended that, "[w]hile many laws that discriminate on the basis of sexual orientation have their origins in sexism, these laws are maintained because of homophobia and

108. Id. (quoting Perry v. Schwarzenegger, 704 F. Supp. 2d 921, 996 (N.D. Cal. 2010), aff'd sub nom. Perry v. Brown, 671 F.3d 1052 (9th Cir. 2012), vacated and remanded sub nom. Hollingsworth v. Perry, 133 S. Ct. 2652 (2013)) (internal quotation marks omitted). A district court in Wisconsin summarized the landscape in this way:

Although the reasoning of the courts rejecting the theory has varied, the general view seems to be that a sex discrimination theory is not viable, even if the government is making a sex-based classification with respect to an individual, because the intent of the laws banning same-sex marriage is not to suppress females or males as a class ... . In other words, courts view this theory as counterintuitive and legalistic, an attempt to "bootstrap" sexual-orientation discrimination into a claim for sex discrimination.

Wolf v. Walker, 986 F. Supp. 2d 982, 1008 (W.D. Wis.), aff'd sub nom. Baskin v. Bogan, 766 F.3d 648 (7th Cir.), cert. denied, No. 14-278, 2014 WL 4425163 (U.S. Oct. 6, 2014). The court then invoked two Seventh Circuit opinions-one in the grooming-code context, which suggested that a rule imposing "comparable burdens on both sexes" might be permissible, id. at 1009 (citing Hayden ex rel. A.H. v. Greensburg Cmty. Sch. Corp., 743 F.3d 569, 581 (7th Cir. 2014)), and the other in a workplace-harassment case, which recognized "a considerable overlap in the origins of sex discrimination and homophobia," but declined to "go so far" as "to conclude that anti-gay bias should, in fact, be understood as a form of sex discrimination," id. (quoting Doe ex rel. Doe v. City of Belleville, 119 F.3d 563, 593 n.27 (7th Cir. 1997) (internal quotation marks omitted)).

109. There is substantial theoretical literature that supports and defends the sexdiscrimination argument's applicability to these laws and policies as well. See supra notes 80-84 and accompanying text (presenting literature on the sex-discrimination argument).

110. Stein, supra note 38 , at 474 . Notably, Stein does not object categorically to the use of the argument but maintains instead that "the sex discrimination argument, given its practical and theoretical pitfalls, if presented at all, should be used with caution." Id. at 515 . 
despite the repeal of many sexist laws." 111 Consequently, he maintains that "to simply deploy the sex discrimination argument against sodomy laws would ... ignore the central role that conceptions of sexual desire play in such laws" and would "overlook[] the distinctive role that "the closet,' and the associated invisibility of lesbians, gay men, and bisexuals, play in the justification and maintenance of sodomy laws and of sexual orientation discrimination generally." 112

In short, Stein argues, "[t]he sociological objection is that, as a cultural fact, lesbians and gay men, not women, suffer the greatest harm from laws that discriminate on the basis of sexual orientation." $113 \mathrm{He}$ adds: "The theoretical objection is that laws that discriminate on the basis of sexual orientation are primarily maintained by homophobia, not by sexism." 114 From a moral standpoint, Stein asserts: "By failing to

111. Id. at 499-500. Of course, many sexist laws have been invalidated by courts rather than repealed by legislatures. See Wendy W. Williams, The Equality Crisis: Some Reflections on Culture, Courts, and Feminism, 14 Women's Rts. L. Rep. 151, 154-56 (1992) (discussing numerous Supreme Court decisions striking down sex-based classifications).

Applying his point to sodomy laws, Stein argues that "[d] espite the fact that sexism played a role in their development, such laws are now maintained primarily by animus towards lesbians and gay men, and by repulsion towards them and the sexual activities they engage in (as well as by repulsion towards sexual activities generally)." Stein, supra note 38, at 500. Although William Eskridge has since shifted to support use of the sexdiscrimination argument, he earlier observed, consistent with Stein's argument, that "[j] udges may find it difficult to understand how denying two gay men the right to marry is driven by an ideology that oppresses straight women." Eskridge, A History, supra note 63 , at 1510 .

112. Stein, supra note 38 , at 500-01.

113. Id. at 502. It bears noting that a number of laws restricting same-sex couples' marriage rights also implicate the rights of different-sex couples who would want some form of nonmarital recognition for their union. See, e.g., Ky. Const. § 233A ("A legal status identical or substantially similar to that of marriage for unmarried individuals shall not be valid or recognized."); N.D. Const. art. XI, $\$ 28$ ("Marriage consists only of the legal union between a man and a woman. No other domestic union, however denominated, may be recognized as a marriage or given the same or substantially equivalent legal effect."); Ohio Const. art. XV, $\$ 11$ ("This state and its political subdivisions shall not create or recognize a legal status for relationships of unmarried individuals that intends to approximate the design, qualities, significance or effect of marriage.").

114. Stein, supra note 38, at 502; see also Nan D. Hunter, The Sex Discrimination Argument in Gay Rights Cases, 9 J.L. \& Pol'y 397, 409 (2001) ("To many people, including many feminists, the sex discrimination argument in gay rights cases seems too clever by half. For some, that is because it seems to be a dodge around what they sense is really going on, which is the subordination of homosexuality.").

Holning Lau has also advanced a theory of aggregate rights of couples not to be discriminated against, including based on sexual orientation, on the ground that "an individual's identity is inextricably linked to her memberships in certain social collectives" and that protecting an "individual requires not only protecting her individual right to associate with those collective entities, but also protecting those entities' aggregate rights to develop." Holning Lau, Transcending the Individualist Paradigm in Sexual Orientation Antidiscrimination Law, 94 Calif. L. Rev. 1271, 1273 (2006). On this couples'-rights theory, 
address arguments about the morality of same-sex sexual acts and the moral character of lesbians, gay men, and bisexuals, the sex discrimination argument 'closets,' rather than confronts, homophobia." 115

The wave of "defense of marriage" laws enacted at both the federal and state levels after the Hawaii Supreme Court's 1993 Baehr ruling arguably reinforces Stein's point that gay people, not sex roles, were the real target of these laws. ${ }^{116}$ As the Supreme Court pointed out in Windsor, Congress's aim in enacting DOMA was to express "both moral disapproval of homosexuality, and a moral conviction that heterosexuality better comports with traditional (especially Judeo-Christian) morality." 117 Further, "[t]he stated purpose of the law was to promote an "interest in protecting the traditional moral teachings reflected in heterosexual-only marriage laws." 118 In other words, if an interest in instantiating sex roles underlies the exclusion of same-sex couples from marriage, it is not nearly as overt as the interest in privileging heterosexuals over gay people. In this sense, sex-stereotyping arguments would obscure or miss the reason why laws exclude same-sex couples from marriage.

In a related vein, Martha Nussbaum argues that disgust-in particular, disgust at sexual intimacy between men-is at the heart of laws that discriminate against lesbians and gay men. ${ }^{119}$ Consistent with this premise, she asserts that opposition to marriage equality is "really not about whether same-sex relationships can involve the content of marriage" but instead is prompted by disgust reactions to the sex acts that might take place between men in those relationships. ${ }^{120}$ For this reason, she characterizes the formal sex-discrimination argument as "legalistic in the

he argues that the sex-discrimination argument is normatively unsatisfactory because it "does not shine due recognition on the couple qua couple." Id. at 1296. He adds: "Although the legal outcome may be functionally equivalent, by not recognizing sexual orientation discrimination as such, the moral recognition of sexual minorities becomes the marginalized stepchild of sex discrimination principles." Id. at 1296-97.

115. Stein, supra note 38, at 503-04. Stein also advances several practical concerns associated with the use of sex-discrimination arguments to confront sexual-orientation discrimination that are less directly relevant here. See id. at 509-10 (discussing, inter alia, the limited effectiveness of sex-discrimination theory against laws that do not make sexbased classifications).

116. See Michael D. Sant'Ambrogio \& Sylvia A. Law, Baehr v. Lewin and the Long Road to Marriage Equality, 33 U. Haw. L. Rev. 705, 725-26 (2011) ("By the time the Baehr v. Lewin litigation came to an end in 1998, thirty-one states had enacted laws to prevent the recognition of same-sex marriages."). This is somewhat ironic given the sexdiscrimination focus of the Hawaii ruling. See supra notes 54-55 and accompanying text (discussing plurality opinion in Baehr v. Lewin).

117. United States v. Windsor, 133 S. Ct. 2675, 2693 (2013) (quoting H.R. Rep. No. 104-664, at 12-13 (1996)) (internal quotation marks omitted).

118. Id.

119. See Martha C. Nussbaum, From Disgust to Humanity: Sexual Orientation \& Constitutional Law 116 (2010) (arguing prejudice against gay men "drives antigay efforts in America" in part because of "profound anxieties about bodily penetrability and vulnerability").

120. Id. at 130 . 
pejorative sense" because "it doesn't quite get at what is really going on," ${ }^{121}$ which is an intent to "penalize[]" homosexuality. ${ }^{122}$

While these objections to the sex-discrimination argument may be persuasive to some readers, none comes close to rendering the sexdiscrimination argument so wrong or implausible as to not be worth making. ${ }^{123}$ Indeed, as noted earlier, even Stein does not take that position. ${ }^{124}$ One need only return to the comments of judges who favor the sex-discrimination argument to see that the theoretical critiques, however interesting and potentially valid, are hardly devastating.

\section{OTHER POSSIBLE EXPLANATIONS FOR THE SEX-DISCRIMINATION ARGUMENT'S LIMITED TRACTION}

So, if the sex-discrimination argument, either in its formal- or substantive-equality iteration, is at least plausible to some and quite persuasive to others, we must search elsewhere to understand why it has gotten so little traction in court. Here, the discussion turns to several types of considerations that might shed light, including litigation logistics, doctrine, social-movement goals, and the mindset of the lawyers and judges who frame these cases. Ultimately, I argue that while these categories of reasons might explain why advocates do not lead with the sex-discrimination argument and why some courts avoid it, they do not, either individually or together, fully explain the sex-discrimination argument's mixed reception of fervent embrace alongside disregard and hostile rejection.

121. Id. at xii-xxiv, 115. For this reason, Carlos Ball characterized the sexdiscrimination argument as having "little rhetorical weight." Carlos A. Ball, Moral Foundations for a Discourse on Same-Sex Marriage: Looking Beyond Political Liberalism, 85 Geo. L.J. 1871, 1880 (1997).

122. Nussbaum, supra note 119 , at 115. For extended commentary on Nussbaum's argument from a scholar who embraces the sex-discrimination theory, see generally Mary Anne Case, A Lot to Ask: Review Essay of Martha Nussbaum's From Disgust to Humanity: Sexual Orientation and Constitutional Law, 19 Colum. J. Gender \& L. 89 (2010) (book review) (critiquing Nussbaum's theory that disgust underlies opposition to legal rights for gay people).

123. Koppelman has responded to Nussbaum by explaining that his argument "does not ... purport to be a complete explanation of where the discrimination is coming from" but rather a claim that "sex discrimination is one of the many wrongs present in antigay discrimination." Koppelman, DOMA, Romer, and Rationality, supra note 84, at 947. Along these lines, Judge Berzon observed in her Latta concurrence that "the gender classification rubric does not adequately capture the essence of many of the restrictions targeted at lesbian, gay, and bisexual people" and acknowledged some exclusions "are primarily motivated by stereotypes about sexual orientation; by animus against people based on their nonconforming sexual orientation; and by distaste." Latta v. Otter, Nos. 14-35420, 1435421, 12-17668, 2014 WL 4977682, at*28 (9th Cir. Oct. 7, 2014) (Berzon, J., concurring).

124. See Stein, supra note 38, at 514-15 ("I have not, however, argued that the sex discrimination argument for lesbian and gay rights should never be made."). 


\section{A. Litigation Logistics}

The logistics of briefwriting and oral argument might partially explain why litigators do not prioritize the sex-discrimination argument, which in turn might help explain why many judges disregard it. ${ }^{125}$ Most basically, the argument's limited success in court minimizes the incentive for the rational, time- and space-limited lawyer to do more than give the argument a mere mention. ${ }^{126}$ Put another way, why should advocates stress an argument that has such a mixed record? There are reasons for doing so, actually, including that the stereotyping argument helps illuminate the gendered nature of a government's justifications restricting marriage to different-sex couples ${ }^{127}$ and that, for some judges, the sexdiscrimination argument, with its accompanying heightened scrutiny, might be a more appealing analytic frame. ${ }^{128}$

But the stereotyping version of the argument, in particular, is relatively complicated to make as compared to demonstrating facial discrimination or setting out either the sexual-orientation or antitargeting argument. ${ }^{129}$ Because it is not self-evident to most people that a malefemale marriage rule rests on impermissible sex stereotypes, ${ }^{130}$ developing the theory takes time, and the relative value of that discussion must be weighed against the realities of word limits for briefs and judicial attention spans. ${ }^{131}$

125. Similar strategic concerns may also lead a judge who finds the argument persuasive not to mention it in the interest of achieving unanimity with colleagues who support a marriage-equality outcome for different reasons.

126. Of course, some lawyers may leave the argument out because they do not find it persuasive, perhaps for the reasons discussed above. See supra Part I.A-C.

127. See Latta, 2014 WL 4977682, at $* 24$ (Berzon, J., concurring) (describing the rationales for excluding same-sex couples from marriage, including gender complementarity of parents, as "laden with the very "baggage of sexual stereotypes" the Supreme Court has repeatedly disavowed" (quoting Califano v. Westcott, 443 U.S. 76, 89 (1979))).

128. This was likely true for the Texas appellate judge who voted to strike down Texas's "homosexual conduct" law at a time when a ruling on sexual-orientationdiscrimination grounds might have seemed politically or doctrinally infeasible. See supra note 56 (discussing the sex-discrimination reasoning in this dissent). Likewise, particularly prior to Windsor, for many judges who were inclined to evaluate sexual-orientation classifications under rational-basis review, the heightened scrutiny required for sex discrimination could have provided an easier path to reject the government's justifications.

129. See supra Part I.A-B (explaining sex-discrimination and other legal theories in marriage cases).

130. See supra text accompanying notes 97-108 (discussing judicial rejection of theory that restrictions on same-sex couples' marriages constitute sex discrimination).

131. Indeed, even at the district-court level where word limits are less typical or rigid, litigators must still decide whether the gains from developing the argument outweigh the costs of filing a long brief. As a point of reference, one recent brief that developed the argument at length devoted roughly four pages of a sixty-page brief to the point. See Harris Plaintiffs' Motion for Summary Judgment Brief, supra note 42, at 23-27 (arguing that Virginia's marriage bans are subject to heightened scrutiny because they contain 
Related to these considerations are concerns about dilution. If an advocate or a judge believes that either the sexual-orientation or the antitargeting argument is particularly strong, there may be reluctance to "pile on" an additional argument that, even if worthy, might divert attention from stronger or otherwise more effective theories. ${ }^{132}$ So, for example, if all judges who are prepared to strike down a marriage exclusion are willing to accept a sexual-orientation-focused theory and only some of those judges will accept a sex-based theory, the sex-based argument may be superfluous and, potentially, costly.

Again, however, given the argument's persistent, albeit occasional, successes and the ways in which it supports the sexual-orientationdiscrimination argument, it is not an obvious candidate for dilutionrelated critiques. Indeed, if dilution-or, further, hostility toward the

explicit sex-based classifications and perpetuate stereotyped notions of familial roles of men and women).

132. This may help explain a particular reluctance to press the argument at the Supreme Court level, where Justice Kennedy had earlier rejected antigay discrimination on other grounds. See Lawrence v. Texas, 539 U.S. 558, 567, 578-79 (2003) ("The petitioners are entitled to respect for their private lives .... Their right to liberty under the Due Process Clause gives them the full right to engage in their conduct without intervention of the government."); Romer v. Evans, 517 U.S. 620, 632-36 (1996) (concluding that Colorado's amendment banning antidiscrimination protections for gay people violated the Equal Protection Clause because it singled out a group without a legitimate purpose).

By contrast, Justice Kennedy was not persuaded by his colleagues' arguments that sex stereotyping was enough to justify the Family Medical Leave Act in Nevada Department of Human Resources v. Hibbs, 538 U.S. 721 (2003), and described "evidence of gender-based stereotypes" as "too remote" to justify granting of family leave. Hibbs, 538 U.S. at 748 (Kennedy, J., dissenting). Nor was he convinced that sex stereotyping was present in ways that justified invalidating Congress's different immigration rules for mothers and fathers in Nguyen v. INS, 533 U.S. 53 (2001). Likewise, Justice Kennedy's opinion in a decision upholding Congress's "partial-birth abortion ban" included a much-criticized observation that one permissible reason for the law derived from congressional concern about women who "come to regret their choice to abort the infant life they once created and sustained." Gonzalez v. Carhart, 550 U.S. 124, 159 (2007). For commentary on that observation, see, e.g., Reva B. Siegel, The Right's Reasons: Constitutional Conflict and the Spread of Woman-Protective Antiabortion Argument, 57 Duke L.J. 1641, 1648-81 (2008) (discussing the supplanting of the constitutional argument that "[a]bortion kills a baby" with the rise of a woman-protective antiabortion argument that "[a]bortion hurts women").

Notably, however, Justice Kennedy indicated his interest in the sex-discrimination argument during the Perry oral argument, though neither Perry nor Windsor ultimately addressed the measures at issue through that lens. He raised the question directly to Charles Cooper, the lawyer for Proposition 8's sponsors: "Do you believe this can be treated as a gender-based classification? .. . It's a difficult question that I've been trying to wrestle with ...." Hollingsworth Transcript, supra note 13, at 13.

Interestingly, too, while Cooper said that his clients "do not think it is properly viewed as a gender-based classification" and pointed to the argument's rejection by many courts, he also conceded the presence of sex-and sex roles-within marriage. Id. He said: "I guess it is gender-based in the sense that marriage itself is a gendered institution, a gendered term, and so in the same way that fatherhood is gendered ... motherhood is gendered, it's gendered in that sense." Id. 
argument ${ }^{133}$-were a serious concern, advocates would not support or encourage submission of amicus briefs elaborating the sex-discrimination theories that have been filed in many marriage cases on appeal. ${ }^{134}$

\section{B. Doctrinal Challenges}

In sync with these concerns are three additional ways that the doctrine itself might limit receptivity to the argument. First, while case law rejecting sex stereotyping is now plentiful, it has developed primarily in the employment context and largely under Title VII, rather than the Equal Protection Clause. ${ }^{135}$ Second, historically, a sex-discrimination ruling would have called into question other laws mandating sexualorientation discrimination in ways that likely caused concern for some judges. At a time when governments criminalized sexual intimacy between same-sex couples, ${ }^{136}$ barred openly gay people from military

133. As noted earlier, courts have sometimes made a special point of rejecting the sex-discrimination argument even while accepting the sexual-orientation-discrimination argument. See supra notes 97-108 and accompanying text.

134. See, e.g., Brief of Amici Curiae National Women's Law Center et al. in Support of Respondent Edith Schlain Windsor on the Merits at 19-33, United States v. Windsor, 133 S. Ct. 2675 (2013) (No. 12-307) [hereinafter NWLC Windsor Brief], 2013 WL 785633, at $* 22-* 27$ (arguing laws that discriminate based on sexual orientation frequently are based on gender stereotypes); NWLC Baskin Brief, supra note 41, at 14-21 (same); NWLC Tanco Brief, supra note 41, at 14-21 (same); Amici Curiae Brief of the National Women's Law Center et al. in Support of Plaintiffs-Appellees \& Affirmance at 13-22, DeBoer v. Snyder, No. 14-1341, 2014 WL 5748990 (6th Cir. Nov. 6, 2014), available at http://williamsinstitute.law.ucla.edu/wp-content/uploads/Obergefell-Brief-2014-5-1-

FINAL-FINAL.pdf (on file with the Columbia Law Review) (same).

135. See supra note 76 (discussing Price Waterhouse, which established gender stereotyping as a form of sex discrimination, and related cases). For a government-employment case that validated a sex-stereotyping theory in an equal-protection analysis, see Glenn v. Brumby, 724 F. Supp. 2d 1284, 1299 (N.D. Ga. 2010) ("[D]iscrimination against a transgendered individual because of their failure to conform to gender stereotypes constitutes discrimination on the basis of sex.").

There is also little doctrine related to the facial-discrimination theory outside the marriage cases. Cf. Tanner v. Or. Health Scis. Univ., 971 P.2d 435, 441-48 (Or. Ct. App. 1998) (rejecting trial court's conclusion that Oregon Health Sciences University's denial of spousal benefits to employees with same-sex partners was sex discrimination and instead finding that sexual-orientation discrimination had occurred).

To the extent the stereotyping argument rests on an antisubordination theory of equality, that theory, too, has been met with relative disinterest by the Supreme Court in equal-protection analysis. See, e.g., Michael C. Dorf, Equal Protection Incorporation, 88 Va. L. Rev. 951, 1009-10 (2002) ("Current Supreme Court doctrine understands equal protection as an antidiscrimination principle rather than an antisubordination principle....”); Reva B. Siegel, Equality Talk: Antisubordination and Anticlassification Values in Constitutional Struggles over Brown, 117 Harv. L. Rev. 1470, 1537-44 (2004) [hereinafter Siegel, Equality Talk] ("[T]he Court embraced anticlassification and repudiated antisubordination when it... refused to make equal protection doctrine responsive to concerns of group disadvantage ....").

136. When Lawrence v. Texas, 539 U.S. 558 (2003), invalidated sodomy laws in 2003, thirteen states criminalized sodomy, of which four punished consensual sexual intimacy only between same-sex partners. Supreme Court Strikes Down Texas Law Banning 
service, ${ }^{137}$ and restricted parental and adoption rights of gay people, ${ }^{138} \mathrm{a}$ sex-discrimination ruling in a gay-rights case would have been difficult to cabin. ${ }^{139}$ Perhaps some of today's reluctance to embrace the argument, when marriage restrictions are typically the only or most prominent measures whose burden falls largely on lesbians and gay men, ${ }^{140}$ may simply be path dependence. ${ }^{141}$

A third doctrinal point concerns the sex-discrimination argument's impact on enduring sex-based distinctions outside of gay-rights cases, such as those in dress and grooming codes and others related to

Sodomy, N.Y. Times (June 26, 2003), http://www.nytimes.com/2003/06/26/politics/26 WIRE-SODO.html (on file with the Columbia Law Review).

137. See “Don’t Ask, Don't Tell” Act, 10 U.S.C. $§ 654(b)$ (2006) (repealed 2010) (providing discharge from armed forces if service member "engaged in, attempted to engage in, or solicited another to engage in a homosexual act"; "stated that he or she is a homosexual or bisexual"; or "has married or attempted to marry a person known to be of the same biological sex").

138. See, e.g., Dep't of Human Servs. v. Howard, 238 S.W.3d 1, 3 (Ark. 2006) (striking down regulation forbidding adults from serving as foster parents if "any adult member of that person's household is a homosexual"); Fla. Dep't of Children \& Families v. Adoption of X.X.G., 45 So.3d 79, 81 (Fla. Dist. Ct. App. 2010) (invalidating ban on adoption by gay people). Some states continue to ban adoption by unmarried, cohabiting couples. See, e.g., Utah Code Ann. § 78B-6-117(3) (LexisNexis 2012) ("A child may not be adopted by a person who is cohabiting in a relationship that is not a legally valid and binding marriage under the laws of this state.").

139. Indeed, this may explain why the Supreme Court did not even address the argument in Lawrence notwithstanding the challenged law's facial classification based on sex. See Lawrence, 539 U.S. 558. For further discussion of Lawrence's relatively narrow rationale, see infra notes $178-180$ and accompanying text.

Mary Anne Case contrasted the sex-discrimination argument with the potential reach of a holding based on the fundamental right to marry:

Not that a sex discrimination holding could not have quite radical implications, but unisex bathrooms and women on football teams are both less frightening, and more easily avoided, through distinction and manipulation of existing doctrine, than are polygamy or adult incest, the proximate entrants in the parade of horribles posed by a privacy/substantive due process holding. A ruling that the constitutional basis for same-sex marriages is a prohibition on sex discrimination gets Hawaii same-sex marriages, but puts very little else at risk.

Case, The Very Stereotype, supra note 32, at 1489.

140. See, e.g., Don't Ask, Don't Tell Repeal Act of 2010, 10 U.S.C. $\$ 654$ (b) (2012) (repealing Don't Ask, Don't Tell's restriction on military service by lesbians, gay men, and bisexuals); Lawrence, 539 U.S. 558, 578-79 (striking down law that criminalized sexual relations between same-sex partners); Romer v. Evans, 517 U.S. 620, 635-36 (1996) (invalidating a ban on antidiscrimination protection for gay, lesbian, and bisexual people in Colorado).

141. Cf. Koppelman, DOMA, Romer, and Rationality, supra note 84, at 949 (observing if sex-discrimination argument "is accepted, the acceptance of same-sex marriage automatically follows, and courts resisted that conclusion as politically impossible," and adding "[n] ow that same-sex marriage is thinkable, it may be possible to address the argument on its merits"). 
parenting and military service. ${ }^{142}$ Although these distinctions have often been sustained against sex-discrimination challenges, ${ }^{143}$ a finding that

142. Another area of concern, though there has been far less litigation, is single-sex educational programming at public schools per the No Child Left Behind Act, Pub. L. No. 107-110, §5131(a) (23), 115 Stat. 1425, 1782 (2002) (codified at 20 U.S.C. $\$ 7215$ (a) (23) (2012)). For extended discussion of related regulations, see David S. Cohen \& Nancy Levit, Still Unconstitutional: Our Nation's Experiment with State-Sponsored Sex Segregation in Education, 44 Seton Hall L. Rev. 339, 341, 384-92 (2014) (arguing singlesex education "promotes an essentialized view" of gender and "perpetuates existing sexbased hierarchies").

143. For hair-length challenges, see, e.g., Harper v. Blockbuster Entm't Corp., 139 F.3d 1385, 1387 (11th Cir. 1998) (dismissing challenge to policy prohibiting male but not female employees from having long hair); Tavora v. N.Y. Mercantile Exch., 101 F.3d 907, 908 (2d Cir. 1996) (upholding employer's policy requiring male but not female employees to have short hair); cf. Kelley v. Johnson, 425 U.S. 238, 247-49 (1976) (upholding sexbased hair-grooming standards for police-force employees against a due-process-based liberty challenge). For discussion of dress codes, see EEOC v. Sage Realty Corp., 507 F. Supp. 599, 611 (S.D.N.Y. 1981) (holding employer could not require female employee to wear "sexually revealing ... uniform"); Marentette v. Mich. Host, Inc., 506 F. Supp. 909, 912 (E.D. Mich. 1980) (implying dress code requiring sexually provocative wear would not be permissible). See generally Jennifer L. Levi, Some Modest Proposals for Challenging Established Dress Code Jurisprudence, 14 Duke J. Gender L. \& Pol'y 243, 243 (2007) (" $[\mathrm{T}]$ he classical gender-based dress code-requiring women to conform to feminine stereotypes and men to conform to masculine stereotypes-has, up to the present, been sustained by a majority of the courts time and again.”).

Regarding parenting, Nguyen v. INS, 533 U.S. 53 (2001), is a hallmark contemporary case sustaining a rule that differentiates between mothers and fathers. In her Nguyen dissent, Justice O'Connor lambasted the majority for its stereotypical treatment of women, writing that "the idea that a mother's presence at birth supplies adequate assurance of an opportunity to develop a relationship while a father's presence at birth does not would appear to rest only on an overbroad sex-based generalization.” Id. at 86 (O'Connor, J., dissenting). She added:

The claim that [the statute] substantially relates to the achievement of the goal of a "real, practical relationship" ... finds support not in biological differences but instead in a stereotype-i.e., "the generalization that mothers are significantly more likely than fathers ... to develop caring relationships with their children." Such a claim relies on "the very stereotype the law condemns," "lends credibility" to the generalization, and helps convert that "assumption" into "a self-fulfilling prophecy."

Id. at 88-89 (citations omitted). But see Caban v. Mohammed, 441 U.S. 380, 389 (1979) (rejecting claim of "universal difference between maternal and paternal relations at every phase of a child's development”).

With respect to the military, while the Supreme Court has not ruled directly on a sexdiscrimination challenge to limits on women's service in combat positions, it has heard challenges related to those limits. See, e.g., Rostker v. Goldberg, 453 U.S. 57, 78 (1981) (upholding exclusion of women from Selective Service registration requirements and observing that " $[\mathrm{m}] \mathrm{en}$ and women, because of the combat restrictions on women, are simply not similarly situated for purposes of a draft or registration for a draft"); Schlesinger v. Ballard, 419 U.S. 498, 508 (1975) (upholding Navy's sex-based discharge and promotion standards that allowed female line officers more time to qualify for promotion, because restrictions on women's service meant these officers otherwise would "not generally have compiled records of seagoing service comparable to those of male lieutenants"). 
different-sex marriage rules are plagued by sex stereotyping might be seen as putting these other sex-differentiated rules at risk. ${ }^{144}$ Here again, though, this fear may partially reflect path dependence, as some sexbased grooming and dress codes, as well as the military's exclusion of women from combat, have come under challenge either in courts or in legislatures and are beginning to give way. ${ }^{145}$

More recently, a lawsuit was filed on behalf of female servicemembers challenging their exclusion from combat positions. See First Amended Complaint for Declaratory \& Injunctive Relief at 1-4, Hegar v. Hagel, No. C 12-06005 EMC (N.D. Cal. Oct. 31, 2013), available at https://www.aclu.org/sites/default/files/assets/2013.10.31_hegar_v_hagel_ fac_as_filed.pdf (on file with the Columbia Law Review).

144. In addition to the examples just noted, the Court's decision sustaining different statutory rape rules for young men and women remains in force today, though nearly all such laws are now gender neutral. See Michael M. v. Superior Court, 450 U.S. 464, 476 (1981) (upholding constitutionality of a criminal law that barred men, but not women, from having sexual intercourse with a minor); Jennifer Ann Drobac \& Leslie A. Hulvershorn, The Neurobiology of Decision Making in High-Risk Youth and the Law of Consent to Sex, 17 New Crim. L. Rev. 502, 513 \& n.31 (2014) (describing states' transition from gendered to gender-neutral age-of-consent laws).

145. With respect to dress and grooming codes, for example, while some are still being upheld, see, e.g., Jespersen v. Harrah's Operating Co., 444 F.3d 1104, 1107, 1113 (9th Cir. 2006) (upholding casino's grooming policy requiring female employees to wear makeup and lipstick, and have their hair "teased, curled, or styled"), others have been found impermissible, see, e.g., Hayden ex rel. A.H. v. Greensburg Cmty. Sch. Corp., 743 F.3d 569, 583 (7th Cir. 2014) (holding hair-length policy applicable only to male basketball players constituted sex discrimination in violation of Title IX); see also Sturgis v. Copiah Cnty. Sch. Dist., No. 30-CV-455-DBJ-FKB, 2011 WL 4351355, at *1 (S.D. Miss. Sept. 15,2011 ) (refusing to dismiss a Title IX challenge to school requirement for yearbook photo of tuxedo for male students and drape for female students). Interestingly, early decisions and EEOC policy also suggested that sex-specific grooming rules-particularly those related to men's hair length-were impermissible without a justification closely related to workplace responsibilities, reinforcing that the sex-discrimination argument might have been less risky than a sexual-orientation discrimination claim at an earlier time. See, e.g., Willingham v. Macon Tel. Publ'g Co., 482 F.2d 535, 538 (5th Cir. 1973) (holding gendered hair-length policy "discriminates on the basis of sex," though also that a company "may justify its grooming code as a bona fide occupational qualification"); EEOC Decision No. 72-1380, 4 Fair Empl. Prac. Cases (BNA) 846, 847 (1972) (holding gendered hair-length policy "discriminates because of sex" and was not a bona fide occupational qualification as a matter of law).

The military's sex-based combat exclusion is also set to come to an end, at least in significant part, if the Department of Defense carries out its recent commitments. In 2013, a Department of Defense memorandum mandated that combat positions be opened to women "as expeditiously as possible" and provided that sex-based exclusions could be maintained only with the personal, nondelegable approval of the Chairman of the Joint Chiefs of Staff and the Secretary of Defense. See Memorandum from Martin E. Dempsey, Chairman of the Joint Chiefs of Staff \& Leon E. Panetta, Sec'y of Def., to the Secretaries of the Military Departments Acting Under Secretary of Defense for Personnel and Readiness and Chiefs of the Military Services 1-2 (Jan. 24, 2013), available at http://www. defense.gov/news/wisrjointmemo.pdf (on file with the Columbia Law Review). 


\section{Social-Movement Strategy}

Social-movement strategy might also explain the advocates' stress on sexual-orientation-based arguments. Given the role of marriage-equality advocacy in the LGBT movement's effort to end discrimination, there is surely something validating about courts condemning this particular form of discrimination. The expressive value of a sexual-orientationbased decision arguably also would reinforce the fair treatment of gay people generally, another movement goal. ${ }^{146}$

Compelling as this observation might be, however, the socialmovement preference for victory based on a particular argument does not map easily onto most litigation, including marriage-equality cases. A case's outcome receives far more public attention than its underlying legal theory. ${ }^{147}$ Further, and consistent with zealous advocacy norms, it is standard in litigation to present multiple theories so long as each theory might help achieve the desired goal. ${ }^{148}$ In the marriage cases, in particular, even advocates who set aside the sex-discrimination argument will advance antitargeting and fundamental-right-to-marry arguments, which presumably have even less expressive value than the sex-discrimination argument.

Likewise, it is no secret that the litigation arms of social movements often approach their goals incrementally not only by the kinds of cases they select but also by the arguments they pursue. ${ }^{149}$ As Michael Klarman has written, advocates for racial and gender equality were "[e]ach confronted with hostile precedent" and "pursued similar strategies: First, try to get one's foot in the door; then, pry it open." ${ }^{150}$ But recognizing

146. As is known from other contexts, including antidiscrimination law, enumeration often has distinct value for both deterrence of harm and empowerment of the protected group. See Romer v. Evans, 517 U.S. 620, 628 (1996) ("Enumeration is the essential device used to make the duty not to discriminate concrete and to provide guidance for those who must comply.”); see also Stephen T. Russell et al., Safe Schools Policy for LGBTQ Students, 24 Soc. Pol'y Rep., no. 4, 2010, at 1, 9 ("[I]n states with comprehensive and enumerated laws, students... reported a higher frequency of staff intervention in instances of harassment.").

147. See infra notes 221-223 (discussing the relationship between judicial opinions and public discourse).

148. Indeed, the Federal Rules of Civil Procedure specifically allow for lawyers to present alternate theories of their case. See Fed. R. Civ. P. 8(d) (2) ("A party may set out two or more statements of a claim.... If a party makes alternative statements, the pleading is sufficient if any one of them is sufficient.").

149. Cf. Ruth Bader Ginsburg, Assoc. Justice, U.S. Supreme Court \& Elena Kagan, Dean, Harvard Law Sch., Remarks Commemorating Celebration 55: The Women's Leadership Summit (Sept. 20, 2008), in 32 Harv. J.L. \& Gender 233, 243 (2009) (noting, in a statement by Justice Ginsburg, that courts are "not in the vanguard of movements for social change").

150. Michael J. Klarman, Social Reform Litigation and Its Challenges: An Essay in Honor of Justice Ruth Bader Ginsburg, 32 Harv. J.L. \& Gender 251, 277 (2009) [hereinafter Klarman, Social Reform Litigation]. Stories abound about careful strategizing both in terms of case selection and theory development. Professor Klarman's article offers 
the value of strategic incrementalism does not tell us which theories are more incremental than others.

Indeed, one might think that a sex-discrimination argument was the most incremental of all in the sense that the jurisprudence condemning sex-based classifications has been established for decades. Moreover, this jurisprudence brings with it the benefit of heightened scrutiny. Courts would not have to conclude that a new classification (sexual orientation) warrants heightened scrutiny or choose between a weak or strong version of rational-basis review. ${ }^{151}$

\section{Psychosocial Explanations}

Viewing the litigation-and, in particular, the judges and lawyers involved in marriage cases-through a psychosocial lens offers yet another possible explanation for why the sex-discrimination argument has not gotten much positive traction in court. On this view, judges' own life experiences may limit their capacity to fully absorb the sexdiscrimination argument. Along these lines, Mary Anne Case has offered what she characterizes as "armchair psychoanalysis" of Ted Olson and David Boies, counsel for the plaintiffs in Perry, that might apply equally well to the judges hearing gay couples' challenges to their exclusion from marriage:

Let me speculate that they are strongly invested in believing that their own marriages do not partake in any respect of the ugly history of marriage law that subordinated wives to husbands and locked them into fixed sex roles. As members of two career couples ... they may also be invested in seeing themselves as free from "stereotype-based beliefs about the allocation of family duties." Yet as fathers whose careers led them to concentrate on breadwinning over caregiving, they have a stake... in affirming the value of their gendered contribution to family life.... [A]cknowledging that there is a residuum of sexstereotyping in the law and social norms of marriage may be so deeply threatening to their own sense of themselves as husbands that they have subconsciously blocked the possibility from their minds. ${ }^{152}$

In short, as discussed earlier, it can be particularly challenging to identify as discriminatory the patterns and practices that are not only widely accepted in society but also characteristic of one's own life. Because most

a thoughtful side-by-side comparison of advocacy strategies pursued by the NAACP Legal Defense Fund and by Ruth Bader Ginsburg and her colleagues at the ACLU Women's Rights Project. See generally id. at 275-301.

151. For discussion of how and when the different tiers of scrutiny came to be established, the relative advantages of each, and the weak and strong versions of rationalbasis review, see generally Suzanne B. Goldberg, Equality Without Tiers, 77 S. Cal. L. Rev. 481, 494-518 (2004).

152. Case, What Feminists Have to Lose, supra note 32, at 1232 (quoting Nev. Dep't of Human Res. v. Hibbs, 538 U.S. 721, 730 (2003)). 
judges are or have been married to different-sex partners, ${ }^{153}$ the argument that the different-sex rule expresses state sanction of sex roles within marriage may cut too close to home to be legible, let alone persuasive.

\section{The Risky-Argument Frame AND the (FEAREd) Social Power of JUDICIAL DECISIONS}

While the assortment of reasons just discussed goes some way toward explaining why judges and litigators regularly ignore, marginalize, or reflexively reject sex discrimination as a framework for analyzing samesex couples' exclusion from marriage, the counterpoints to each, along with the argument's continued occasional success, suggest that more is at work.

Here is where a theory of risky arguments comes in to play. In part, viewing the sex-discrimination argument through the risky-argument frame calls attention to the way that the argument challenges decisionmakers' own naturalized sense of sex and gender, as just discussed. While courts have sometimes been willing to reject certain deeply naturalized forms of sex discrimination-including, for example, the view that men are "more conversant with business affairs" 154 and "the domestic sphere... properly belongs to the domain and functions of womanhood" 155 _ those changes have come only over time and in a social context that supported them. ${ }^{156}$ Others have remained sticky and deeply entrenched, either in the law or in the surrounding society. ${ }^{157}$ Just think of the cottage industry devoted to helping us understand the differences between men and women ${ }^{158}$ and the raft of judicial decisions sustaining

153. Even those who have not been married no doubt have close family or friends who are.

154. Frontiero v. Richardson, 411 U.S. 677, 683 (1977) (plurality opinion) (quoting Brief for Respondent at 12, Reed v. Reed, 404 U.S. 71 (1971) (No. 70-4), 1971 WL 133597).

155. Id. at 684 (quoting Bradwell v. Illinois, 83 U.S. (14 Wall.) 130, 141 (1872) (Bradley, J., concurring in the judgment)).

156. See Klarman, Social Reform Litigation, supra note 150, at 279 (explaining that the Supreme Court rejected a preference for husbands over wives as estate administrators in Reed, 404 U.S. 71, only after the Idaho legislature had already "implicitly acknowledged that the law embraced an obsolete sex stereotype by prospectively repealing it").

157. For a discussion of how sticky intuitions related to homosexuality, gender roles, and sexuality more generally enable distinctions based on sexual orientation to continue, see generally Suzanne B. Goldberg, Sticky Intuitions and the Future of Sexual Orientation Discrimination, 57 UCLA L. Rev. 1375 (2010).

158. For elaboration of widespread views about differences between men and women, see, e.g., John Gray, Men Are from Mars, Women Are from Venus: The Classic Guide to Understanding the Opposite Sex 5 (1992) (arguing that "men and women communicate[,] ... think, feel, perceive, react, respond, love, need, and appreciate differently"). Although this type of social assertion alone may not be enough to justify formal sex discrimination in many instances-see, e.g., United States v. Virginia, 518 U.S. 515, 541-46 (1996) (rejecting concern that admitting women "would downgrade [Virginia 
different rules for men and women regarding hairstyle, jewelry, or clothing. ${ }^{159}$ More generally, the social and legal costs of transgressing sex and gender boundaries remain high. ${ }^{160}$ Similarly, many judges, and others, continue to defend a legally sanctioned preference for people to be heterosexual rather than gay or bisexual. ${ }^{161}$

\section{A. Concerns About the Social Power of Legal Reasoning}

It is worth highlighting a second, intertwined dimension of the frame, which focuses attention on the inchoate concerns judges might have about the social power of their decisions. That is, perhaps the perception of risk is related not only to an adjudicator's own sense of the natural order but also a sense (inflated, as I will argue in a moment) that a decision in a case has the power to alter that natural order and not just the practices associated with it. In the context here, the concern would be that judicial rejection of sex-based distinctions will unsettle genderbased differences altogether in addition to any particular effects the decision would have on marriage. ${ }^{162}$

Military Institute's] stature, destroy the adversative system and ... the school" because inherent differences between men and women are neither "solidly grounded" nor an exceedingly persuasive justification) — the pervasive belief in essential differences between men and women contributes to the difficulty faced by those who seek to challenge distinctions based on sex that are seen as natural.

159. See supra note 143 (discussing sex-based distinctions outside of gay-rights cases).

160. For further discussion of the institutional and physical violence against those who transgress gender-role expectations, see Jaime M. Grant, Lisa A. Mottet \& Justin Tanis, Injustice at Every Turn: A Report of the National Transgender Discrimination Survey 3 (2011), available at http://www.thetaskforce.org/downloads/reports/reports/ ntds_full.pdf (on file with the Columbia Law Review) (finding high rates of discrimination against transgender individuals in education, employment, housing, and other settings); Nat'l Coal. of Anti-Violence Programs, Lesbian, Gay, Bisexual, Transgender, Queer and HIV-Affected Hate Violence in 2012, at 8-9 (2013), available at http://www.avp.org/ storage/documents/ncavp_2012_hvreport_final.pdf (on file with the Columbia Law Review) (finding transgender people, transgender people of color, and transgender women were two to three times more likely than others to experience both police and physical violence). See generally Dean Spade, Normal Life: Administrative Violence, Critical Trans Politics, and the Limits of the Law (2011).

161. See, e.g., Jackson v. Abercrombie, 884 F. Supp. 2d 1065, 1111-19 (D. Haw. 2012) (upholding statute banning marriage for same-sex couples), vacated as moot, No. 12-16995, 2014 WL 5088199 (9th Cir. Oct. 10, 2014); see also supra notes 117-118 and accompanying text (describing Congress's aim in enacting DOMA).

162. See infra note 171 (discussing judicial response to sex-discrimination claims against grooming codes). Legislators often seem to sense their power similarly, as illustrated by identity-related laws enacted for the purported purpose of serving the general welfare, such as those restricting women from becoming bartenders or prohibiting pregnant women from teaching young children, although a full exploration of this point is beyond the scope here. Cf. Cleveland Bd. of Educ. v. LaFleur, 414 U.S 632, 647-48 (1974) (rejecting restriction on pregnant teachers); Goesaert v. Cleary, 335 U.S. 464, 465-66 (1948) (sustaining sex-based bartending restriction). See generally Suzanne B. Goldberg, Morals-Based Justifications for Lawmaking: Before and After Lawrence v. Texas, 88 Minn. L. 
To be sure, there is no record of adjudicators openly stating that their decisions have this power or expressing reluctance about exercising power in this way. Early cases that rejected sex-discrimination arguments, however, can be read to reflect a similar anxiety about judicial disruption of social sex roles. ${ }^{163}$ Certainly, Justice Bradley's nineteenth-century defense of Illinois's exclusion of Myra Bradwell from the state bar suggested as much when he not only proclaimed " $[\mathrm{t}]$ he paramount destiny and mission of woman ... to fulfill the noble and benign offices of wife and mother" per the "law of the Creator," but also stressed that "the rules of civil society must be adapted to the general constitution of things." 164

Likewise, nearly a century later, the Court rejected a challenge to women's automatic exemption from jury service in Florida on the ground that, " $[\mathrm{d}]$ espite the enlightened emancipation of women from the restrictions and protections of bygone years, and their entry into many parts of community life formerly considered to be reserved to men, woman is still regarded as the center of home and family life." ${ }^{165}$ And again, in 2001, a majority of the Court sustained a rule treating foreignborn children of American mothers differently from children of American fathers because " $[\mathrm{t}]$ he difference between men and women in relation to the birth process is a real one." 166 The dissent, by contrast, had argued that the sex-based citizenship rule "finds support not in biological differences but instead in a stereotype-i.e., 'the generalization

Rev. 1233 (2004) (exploring difficulties associated with judicial evaluation of moral rationales and concluding morality should not be a permissible justification for lawmaking).

163. Reva Siegel's observation about the evolution of politics regarding women's suffrage resonates with this point:

Before the rise of the suffrage movement no one thought that the principles of the American Revolution required enfranchising women.... The suffragists sought to change constitutional understandings held by members of their community.... Their argument was, if anything, too powerful. The suffrage claim challenged customary understandings about the natural domain of constitutional principles in ways that drew into question fundamental social arrangements.

Siegel, Constitutional Culture, supra note 11, at 1358.

164. Bradwell v. Illinois, 83 U.S. (14 Wall.) 130, 141-42 (1872) (Bradley, J., concurring) (emphasis added). Similar reasoning appears in decades of decisions that sustained antimiscegenation laws on the grounds that racial intermarriage violated the laws of nature. See, e.g., Scott v. State, 39 Ga. 321, 323 (1869) (upholding state's antimiscegenation statute based on "[o] ur daily observation . . . that the offspring of these unnatural connections are generally sickly and effeminate, and that they are inferior in physical development and strength, to the full-blood of either race"); W. Chester \& Phila. R.R. v. Miles, 55 Pa. 209, 213-14 (1867) (defending decision as "not prejudice, nor caste, nor injustice of any kind, but simply to suffer men to follow the law of races . . and not to compel them to intermix contrary to their instincts").

165. Hoyt v. Florida, 368 U.S. 57, 61-62 (1961). It took fourteen years for the Court to reverse course on this issue. See Taylor v. Louisiana, 419 U.S. 522, 533 (1975) (striking down rule excluding women from jury pools).

166. Nguyen v. INS, 533 U.S. 53, 73 (2001). 
that mothers are significantly more likely than fathers... to develop caring relationships with their children." 167

In these and other cases, the judicial fear-albeit unexpressedseems to be that a categorical legal rejection of sex-based rules would also erase social distinctions between men and women. ${ }^{168}$ If this fear was not operative, we would likely see a more consistent set of decisions holding that jurisprudential and statutory prohibitions of sex discrimination really mean that sex-based lines cannot stand. ${ }^{169}$

More graphically, it is almost as though there is an internalized sense, on the part of at least some judges, that if sex-based rules were not tolerated on occasion, we would all wind up in unisex tunics, having lost our sexed and gendered bearings. ${ }^{170}$ Indeed, this fetishization of the law's power over identity may be why sex-discrimination law in the Title VII context has often stopped so sharply at dress and grooming codes. ${ }^{171}$

167. Id. at 89 (alteration in original) (quoting Miller v. Albright, 523 U.S. 420, 48283 (1998) (Breyer, J., dissenting)).

168. Cf. Siegel, Constitutional Culture, supra note 11, at 1413 ("Not only the definition of sex classification but also judgments about what counts as a sex stereotype continue to evolve as they are socially contested.").

169. To be sure, the Court has explained its decisions to sustain sex-based rules on the grounds that legislators had adequate justifications in those instances. See, e.g., Nguyen, 533 U.S. at 62-63 (justifying decision to sustain sex-based rule related to parents of foreign-born children on grounds of women's and men's different roles in childbirth). To the extent one is dubious of these justifications, as was the dissent in Nguyen, judicial discomfort with upsetting rules reflecting "natural" sex differences might explain why some distinctions have remained while most others have been invalidated. See also Williams, supra note 111, at 152-55 (addressing ways in which the Supreme Court's sexdiscrimination jurisprudence varies by context).

170. Concerns about gendered bathrooms and disregard of women's role in giving birth often arise in casual conversation on this point, though neither seems to be expressed extensively in judicial opinions, other than Nguyen (discussed supra notes 132, 143, 166-167 and accompanying text, and infra note 194 and accompanying text), or the law-review literature related to the sex-discrimination argument's work in these kinds of cases. Cf. Neil S. Siegel, "Equal Citizenship Stature": Justice Ginsburg's Constitutional Vision, 43 New Eng. L. Rev. 799, 837 n.205 (2009) (citing Ruth Bader Ginsburg, The Fear of the Equal Rights Amendment, Wash. Post, Apr. 7, 1975, at A21) (discussing Justice Ginsburg's view regarding gendered bathrooms in Equal Rights Amendment debates that "[s] eparate places to disrobe, sleep, perform personal bodily functions are permitted, in some situations required, by regard for individual privacy"). Reva Siegel has observed that "the 'potty issue' did not die with the ERA. Scholars continued to raise the question of segregated bathrooms to highlight the difference between race discrimination and sex discrimination. And constitutional law casebooks continued to discuss the potty issue, canonizing it as a central question of sex discrimination law." Reva B. Siegel, She the People: The Nineteenth Amendment, Sex Equality, Federalism, and the Family, 115 Harv. L. Rev. 947, 958 n.26 (2002) (citations omitted).

171. The law's general reluctance to interfere with employers' business decisions is also at play in dress- and grooming-code cases. See D. Wendy Greene, A Multidimensional Analysis of What Not to Wear in the Workplace: Hijabs and Natural Hair, 8 Fla. Int'l U. L. Rev. 333, 351 (2013) [hereinafter Greene, What Not to Wear] (discussing "high level of deference that courts accord to employers in their enactment and enforcement of grooming codes," specifically with reference to hairstyle); cf. Elizabeth M. Adamitis, 
As Wendy Williams suggested when reflecting on why other women'srights cases stopped similarly short of rejecting sex-based distinctions, particularly in the context of military service and parenting, this selective tolerance of sex discrimination in particular contexts may signal the "cultural limits of the equality principle." 172

From this vantage point, it is not surprising that most judges decline to endorse arguments with the potential for such pervasive legal and social effects. These arguments are, simply put, exactly the sort of risky arguments most courts would rather avoid. Indeed, the profound challenge the sex-discrimination argument poses to deeply rooted social norms may also help explain why some judges, rather than avoid the argument, go out of their way to reject it even as they rule in favor of marriage equality. ${ }^{173}$

\section{B. Avoiding the Risky Argument: A Gay-Rights Case Study}

The trajectory of the three major gay-rights cases decided by the Supreme Court since 1996-Romer v. Evans, Lawrence v. Texas, and United States $v$. Windsor-reinforces the risky-arguments account offered here. ${ }^{174}$ In none of these cases did the Court take up the sex-discrimination question or even, in an explicit way, the constitutional status of sexualorientation-based classifications. ${ }^{175}$

Appearance Matters: A Proposal to Prohibit Appearance Discrimination in Employment, 75 Wash. L. Rev. 195, 199-211 (2000) (reviewing limited federal and state protections for appearance-based discrimination as form of sex discrimination).

172. Williams, supra note 111 , at 156; see also Koppelman, DOMA, Romer, and Rationality, supra note 84, at 949 (observing that the "bounds of legitimate legal argument are not set by rules, but by custom and usage").

173. See supra notes 103-108 and accompanying text (citing examples from courts in Oklahoma, Oregon, New Mexico, and Idaho).

174. In the interest of disclosure, I was co-counsel in Romer and Lawrence (my formal involvement in Lawrence was in the state courts) and consulted informally with counsel for Edith Windsor.

175. United States v. Windsor, 133 S. Ct. 2675, 2693-94 (2013) (striking down DOMA on an antitargeting theory without explicit reliance on constitutional theories of sex or sexual-orientation discrimination); Lawrence v. Texas, 539 U.S. 558, 564 (2003) (framing inquiry as implicating a right to liberty, not sex or sexual-orientation discrimination); Romer v. Evans, 517 U.S. 620, 632-33 (1996) (relying on antitargeting rationale in striking down Colorado amendment).

Unlike the laws at issue in Windsor and Lawrence, the Colorado amendment that banned antidiscrimination protections for gay people at issue in Romer did not contain an express sex-based classification, so would not have been susceptible to the facialdiscrimination argument that could have been made against the Texas "homosexual conduct" law and DOMA, both of which drew explicitly sex-based classifications. Compare Windsor, 133 S. C. at 2683 (stating DOMA, 1 U.S.C. $\$ 7$ (2012), defines marriage as between "one man and one woman"), and Lawrence, 539 U.S. at 562, 564 (describing Texas's "homosexual conduct" law, which criminalized conduct only when engaged in by "persons of the same sex"), with Romer, 517 U.S. at 620 (evaluating a state constitutional amendment that "prohibit[ed] all legislative, executive or judicial action at any level of 
In Romer, for example, the Court did not engage the question whether Colorado's ban on antidiscrimination protections for gay people amounted to impermissible sexual-orientation discrimination, ${ }^{176}$ much less the sex stereotyping arguably embedded in the amendment's hostility toward gay people. Instead, Colorado's amendment fell into a smaller, more discrete category of discrimination of an unusual character because it "singl[ed] out a certain class of citizens for disfavored legal status or general hardships." 177

In Lawrence, sex discrimination was an even more obvious reason to reject the Texas law that criminalized specified sexual acts only for samesex partners. ${ }^{178}$ But the Court opted instead to rule, on due-process grounds, that protections of individual liberty forbid governments from criminalizing private sexual conduct between consenting adults, ${ }^{179}$ a

state or local government designed to protect... 'homosexual, lesbian or bisexual orientation, conduct, practices or relationships'” (quoting Colo. Const. art. II, § 30b)).

176. The plaintiffs did not pursue the sexual-orientation-based heightened-scrutiny argument at the Supreme Court, although they had pursued it in the state-court litigation. See Evans v. Romer, No. 92 CV 7223, 1993 WL 518586, at *9 (D. Colo. Dec. 14, 1993) ("First [plaintiffs] claim that homosexuals and bisexuals ought to be found to be a suspect class and entitled to strict scrutiny review for that reason. Second they claim that homosexuals and bisexuals ought to be found to be a quasi-suspect class and be entitled to heightened scrutiny review."), aff'd, 882 P.2d 1335 (Colo. 1994), aff'd, 517 U.S. 620. Instead, their brief focused heavily on the political-participation theory embraced by the Colorado Supreme Court, Evans, 882 P.2d at 1343, as well as the animus-focused argument that the Court ultimately adopted. See Brief for Respondents at 14, Romer, 517 U.S. 620 (No. 94-1039), 1995 WL 417786 ("Amendment 2... insulates against legal control or review all instances of governmental and private discrimination based on a particular characteristic, regardless of context or circumstances. Such a blanket foreclosure of responsiveness to one group's interests is rationally related to one purpose alone-the expression of antipathy toward gay people.”).

Still, arguments focused on sexual-orientation discrimination were before the Court in amicus briefs. See, e.g., Brief of the Human Rights Campaign Fund as Amici Curiae in Support of Respondents, Romer, 517 U.S. 620 (No. 94-1039) [hereinafter HRC Romer Brief], 1995 WL 17008436, at *5-*25 (arguing that governmental classifications based on sexual orientation require strict scrutiny). For more on the Romer litigation, see generally Lisa Keen \& Suzanne B. Goldberg, Strangers to the Law: Gay People on Trial (1998).

177. Romer, 517 U.S. at 633 (citation omitted).

178. As noted earlier, a state-court appellate judge fully embraced the theory. See supra note 56 (discussing dissenting opinion in Lawrence in state court).

179. See Lawrence, 539 U.S. at 578. Here, unlike in Romer, the parties challenging the law had asked the Court to rule directly on the sexual-orientation-discrimination question under equal-protection doctrine. Id. at 574. Amici also advanced the sex-discrimination argument. See Brief of NOW Legal Defense \& Education Fund as Amicus Curiae in Support of Petitioners at 4-21, Lawrence, 539 U.S. 558 (No. 02-102), available at http:/ / findlawimages.com/efile/supreme/briefs/02-102/02-102.mer.ami.now.pdf (on file with the Columbia Law Review) (arguing that Texas law requires adherence to sex stereotypes and discriminates facially based on sex); see also Brief of Petitioners at 32 n.24, Lawrence, 539 U.S. 558 (No. 02-102), 2003 WL 152352 ("Heightened equal protection scrutiny is appropriate for laws . . that use a sexual-orientation-based classification. It is also appropriate where, as here, the law employs a gender-based classification to discriminate against gay people.”). As a reason for not addressing the equal-protection 
ruling that would not call into question restrictions in either the military or marriage that excluded gay people almost categorically. ${ }^{180}$

Windsor illustrated even more clearly the Court's preference for the narrow, cabinable argument over the broader, norm-confronting argument. ${ }^{181}$ Rather than take up the parties on their vigorous debate over whether heightened scrutiny should apply to classifications that burden gay people, ${ }^{182}$ or take up amici on the sex-discrimination question, ${ }^{183}$ the Court updated and reapplied a Romer-style analysis. ${ }^{184}$ The constitutional

argument, the majority wrote that " $[\mathrm{w}]$ ere we to hold the statute invalid under the Equal Protection Clause some might question whether a prohibition would be valid if drawn differently, say, to prohibit the conduct both between same-sex and different-sex participants." Lawrence, 539 U.S. at 575.

180. Justice O'Connor's concurring opinion, which advanced the equal-protection argument, tried to distinguish the military and marriage cases by suggesting that while "national security or preserving the traditional institution of marriage" might be acceptable grounds for discrimination against gay people, they were inapplicable to the Texas law. Lawrence, 539 U.S. at 585 (O'Connor, J., concurring in the judgment). Although most efforts to extend Lawrence to protect other forms of private conduct have failed, some might question whether this turned out to be the lower-impact choice now that Lawrence has been relied on successfully, at least in a district court, to restrict a state from criminally punishing those who engage in polygamy. See Brown v. Buhman, $947 \mathrm{~F}$. Supp. 2d 1170, 1222-25 (D. Utah 2013) (applying Lawrence to strike down the cohabitation prong of Utah's statutory ban on polygamy), aff'd sub nom. Brown v. Herbert, No. 2:11-CV-0652-CW, 2014 WL 4249865 (D. Utah Aug. 27, 2014).

181. See United States v. Windsor, 133 S. Ct. 2675, 2689-96 (2013) (invalidating DOMA but avoiding broad classification-based analysis).

182. See, e.g., Windsor Respondent's Merits Brief, supra note 42, at 17-32 (developing the argument for heightened scrutiny of DOMA's classification based on a sexual-orientation-discrimination theory); Brief for the United States on the Merits Question at 18-36, Windsor, 133 S. Ct. 2675 (No. 12-307) [hereinafter U.S. Windsor Merits Brief], 2013 WL 683048 (arguing section 3 of DOMA created an impermissible classification based on sexual orientation and that the classification should be subject to heightened scrutiny); Brief on the Merits for Respondent Bipartisan Legal Advisory Group of the U.S. House of Representatives at 49-59, Windsor, 133 S. Ct. 2675 (No. 12-307), 2013 WL 267026 (arguing that laws creating classifications based on sexual orientation should not be subject to heightened scrutiny).

183. See NWLC Windsor Brief, supra note 134, at 2 ("Laws that discriminate based on sexual orientation share with laws that discriminate based on sex a similar basis in overbroad gender stereotypes about the preferences and capacities of men and women.”).

184. The federal district court that struck down Utah's exclusion of same-sex couples from marriage made this observation directly:

The Supreme Court's opinion in Windsor is similar [to that in Romer]. The Court did not analyze the legitimate interests cited by DOMA's defenders as would be typical in a rational basis review. Instead, the Court focused on the "design, purpose, and effect of DOMA," and held that the law's "avowed purpose and practical effect" was "to impose a disadvantage, a separate status, and so a stigma' on same-sex couples that a state had permitted to wed. Because DOMA's "principal purpose" was "to impose inequality," the Court ruled that the law deprived legally wed same-sex couples of "an essential part of the liberty protected by the Fifth Amendment." 
concern, the Court wrote, was triggered because DOMA was a "[d]iscrimination [] of an unusual character." 185 In other words, it was the statute's "purpose and effect to disparage" same-sex couples that the Court found troubling, ${ }^{186}$ with no reference to the decision's implications for state marriage laws. As Chief Justice Roberts pointed out in dissent, "[T]he logic of [the Court's] opinion does not decide[] the distinct question whether the States, in the exercise of their 'historic and essential authority to define the marital relation,' ... may continue to utilize the traditional definition of marriage." 187

\section{RISKY ARGUMENTS: SYNERGIES WITH INCREMENTAL ADVOCACY}

One might reasonably conclude, in light of the discussion to this point, that it is best for advocates to avoid or at least minimize reliance on arguments that push judges to confront their naturalized assumptions about social norms and practices. By limiting confrontations about sex and gender roles in marriage cases, in particular, advocates might also limit their risk of generating judicial discomfort and resistance. Likewise, one might expect judges who agree with norm-challenging arguments to set them aside in favor of others that their colleagues find easier to grasp. Yet, at the same time, there are real costs to this approach.

This Part first looks closely at those costs and then evaluates whether wins on more discrete, incremental arguments are really so different in their effect from wins that rest on risky arguments. At least in connection with gay-rights cases generally, and marriage cases more specifically, the Supreme Court's rulings on relatively discrete legal theories have proven to be powerful in ways well beyond what the doctrinal terms would suggest. This is not to say that winning marriage equality on a sex-

Kitchen v. Herbert, 961 F. Supp. 2d 1181, 1208 (D. Utah 2013) (citations omitted) (quoting Windsor, 133 S. Ct. at 2689, 2692-94, 2707), aff'd, 755 F.3d 1193 (10th Cir.), cert. denied, No. 14-124, 2014 WL 3841263 (U.S. Oct. 6, 2014).

185. Windsor, 133 S. Ct. at 2692 (first alteration in original) (quoting Romer v. Evans, 517 U.S. 620, 633 (1996)) (internal quotation marks omitted).

186. Id. at 2696.

187. Id. (Roberts, C.J., dissenting). One might argue that this is precisely the sort of minimalist ruling that the Court should reach, particularly when other related cases are in the pipeline. See supra note 27 (examining why courts may favor minimalistic approach to social-change cases); see also Cass R. Sunstein, One Case at a Time: Judicial Minimalism on the Supreme Court 4 (2001) ("Decisional minimalism ... reduce[s] the burdens of judicial decision . . . and more fundamentally, minimalism is likely to make judicial errors less frequent and (above all) less damaging.").

Further, one might argue that the sex-discrimination cases did not actually involve discrimination of an unusual character so that that analytic framework would have been an awkward fit there, while it does fit the gay-rights cases. But it can hardly be said that legally enforced discrimination against gay people was unusual at the time of Romer or even at the point when Windsor was decided; indeed, it is no secret, even to the Court, that these forms of discrimination were-and with respect to marriage, remained at the time of Windsor-pervasive in the United States. See, e.g., HRC Romer Brief, supra note 176, at *9*15 (describing "history of discrimination" against gay, lesbian, and bisexual individuals). 
discrimination theory would not have been more powerful; to the contrary, the discussion of costs below suggests it likely would have been. But the difference has not proven significant.

This observation prompts the third question explored below: How have rulings on incremental grounds become so powerful while eliding some of the challenges risky arguments bring? The last part of the discussion then steps back to consider the synergies that are possible by bringing together the conceptual force of risky arguments with the risk minimization of more discrete approaches.

\section{A. The Costs of Sidestepping the Sex-Discrimination Argument}

Most basically, in the marriage-litigation context, the sexdiscrimination argument may be persuasive to some judges who are otherwise not inclined to strike the different-sex couple requirement on sexual-orientation-discrimination grounds. ${ }^{188}$ Surely it is a loss not to make the argument in this circumstance.

But let us assume a judge is open to striking the exclusion of samesex couples from marriage on other grounds. In this case, how might it matter if the sex-discrimination argument is not pressed? Three points come to mind. First, the sex-discrimination argument helps to discredit the usual justifications for the exclusion by shedding light on the sex stereotypes embedded in them. For example, governments frequently invoke children's interests in having a male and a female parent or the state's interest in privileging "natural" procreation. ${ }^{189}$ Viewing these rationales through the lens of a sex-discrimination argument can help

188. Although perhaps unlikely, a judge might be unwilling to recognize the disparate impact of a rule that does not differentiate explicitly based on sexual orientation. Cf. Latta v. Otter, Nos. 14-35420, 14-35421, 12-17668, 2014 WL 4977682, at *15 (9th Cir. Oct. 7, 2014) (Berzon, J., concurring) ("[S] exual orientation does not appear as a qualification for marriage' under these laws; sex does." (quoting Baker v. State, 1744 A.2d 864, 905 (Vt. 1999) (Johnson, J., concurring in part and dissenting in part))).

This same judge might also believe that rational-basis review should apply to sexualorientation-based classifications but heightened scrutiny should apply to sex-based classifications and that the proffered justifications for a different-sex marriage-eligibility rule satisfy the former but fail the latter. Indeed, the U.S. government took the position that DOMA failed heightened scrutiny but not rational-basis review. See U.S. Windsor Merits Brief, supra note 182, at 52 ("The government has concluded that... DOMA Section 3 cannot be sustained under [heightened scrutiny]. If the Court disagrees and applies rational-basis review, the government ... does not challenge the constitutionality of Section 3 under that highly deferential standard.”).

189. See Brief of Appellants at 63-64, 83, Kitchen, 755 F.3d 1193 (No. 13-4178), 2014 WL 580550 (arguing "mother-father parenting" provides an essential contribution to healthy child development and that the "need to ensure adequate procreation" explains why "marriage has always been conceived as a union of a man and a woman for the purpose of having children"); William C. Duncan, The State Interests in Marriage, 2 Ave Maria L. Rev. 153, 154-60 (2004) (discussing justifications advanced for different-sex marriage rule in litigation including procreation and child rearing). 
expose their impermissible assumptions about men and women's roles; ${ }^{190}$ to omit the argument is to give up a potentially powerful analytic tool.

Second, the omission risks being read to signal advocates' doubts that gender stereotypes actually permeate the rationales often given for excluding same-sex couples from marriage. Without that direct challenge to the government's mother-father preference and other similar justifications, a judicial reader might wonder whether the advocates accept those rationales as legitimate even while maintaining their inadequacy.

Third, and perhaps most importantly for this Essay's purposes, a win on the sex-discrimination argument would arguably have a broader impact than a win on a discrimination-of-an-unusual-character antitargeting theory or even a win on a sexual-orientation-discrimination theory. To the extent a court recognizes that sex stereotyping is integral to sexual-orientation discrimination, the analysis should prompt heightened scrutiny of other instances of sexual-orientation discrimination, even if the level of scrutiny for sexual-orientation-based classifications remains undecided. In other words, if it is understood that treating gay and nongay people differently effectuates sex stereotypes, it is difficult to imagine a circumstance in which a court could sustain any antigay discrimination. ${ }^{191}$

By contrast, a win on a sexual-orientation-discrimination theory in the marriage context might not govern a case in which a school seeks to exclude a gay-straight alliance. ${ }^{192}$ The marriage ruling would be influential, of course, but it would not be conclusive of that action's invalidity in the way that a decision recognizing the sex discrimination embedded in different treatment based on sexual orientation arguably would be. ${ }^{193}$

Moreover, a win on a sex-stereotyping theory in the marriage context might have carryover benefits to the few remaining areas in

190. See Widiss et al., supra note 32, at 463 ("Exposing the sex stereotypes at play ... discredit[s] the proffered rationalizations as insufficient to meet even 'rational basis' review."); see also supra note 77 (discussing Judge Berzon's recent rejection based on sexstereotyping jurisprudence of the argument that gender complementarity between parents provides benefits).

191. See Widiss et al., supra note 32 , at 489 ("[R] ecognizing that many of the purported justifications for these [different-sex] requirements are largely or entirely based on sex stereotypes makes clear that such justifications cannot be an appropriate basis for government action, even if legislators and others sincerely believe in their validity.”).

192. Cf. Carver Middle Sch. Gay-Straight Alliance v. Sch. Bd., No. 5:13-CV-623-OC10PRL, 2014 WL 897072, at *6 (M.D. Fla. Mar. 6, 2014) (expressing skepticism about plaintiffs' challenge to school board's nonrecognition of a gay-straight alliance). But see Gonzalez ex rel. Gonzalez v. Sch. Bd., 571 F. Supp. 2d 1257, 1267-69 (S.D. Fla. 2008) (holding school board's refusal to recognize gay-straight alliance violated students' rights under the Equal Access Act and First Amendment).

193. Cf. Latta v. Otter, Nos. 14-35420, 14-35421, 12-17668, 2014 WL 4977682, at *28 (9th Cir. Oct. 7, 2014) (Berzon, J., concurring) ("Although the gender stereotyping so typical of sex discrimination may be present [in discrimination directed expressly at lesbians, gay men, and bisexuals], those restrictions are better analyzed as sexual orientation discrimination ...." (citation omitted)). 
which sex-discriminatory rules have been sustained. For example, if a state is not permitted to presume that mothers and fathers play different roles in a way that could justify restricting marriage to different-sex couples, it may be more difficult for the government to sustain the distinction between mothers and fathers in federal laws and policies that impose extra burdens on fathers of foreign-born children in the immigration context. ${ }^{194}$ Quite possibly, too, if the sex stereotyping in marriage becomes more apparent, the sex stereotyping present in grooming codes would become more visible and less tolerable as well. ${ }^{195}$

\section{B. The High Impact of Discrete-Argument Wins in Marriage Cases}

Notwithstanding these potential costs, a ruling that strikes a discriminatory law on a relatively discrete argument may engender legal and societal change in ways similar to one that expressly rejects deep-rooted stereotypes. In the marriage context, this means that a judicial decision need not directly recognize and disavow the sex stereotypes embedded in a different-sex marriage rule to have an impact, both legally and socially, on those stereotypes' validity. As a result, the costs of not making the argument may be somewhat diminished.

The marriage rulings following United States $v$. Windsor illustrate the point. Winning DOMA's invalidation on a discrimination-of-an-unusualcharacter theory did not necessarily decide the question whether states could continue to exclude same-sex couples from marriage. ${ }^{196}$ If Windsor

194. To be fair, it is not clear that a sex-discrimination win in marriage would have resulted in a different outcome in Nguyen, because the majority found that the different rules were justified in part by men's and women's distinct relationships to the foreign-born child's birth. See Nguyen v. INS, 533 U.S. 53, 73 (2001) (highlighting rule's connection to "our most basic biological differences-such as the fact that a mother must be present at birth but the father need not be"). Further, the Nguyen concurrence turned on the plenary authority of Congress in matters of immigration and sovereignty. Id. at 73-74 (Scalia, J., concurring).

Still, a strong sex-stereotyping decision could potentially add more weight to arguments about the sex-role expectations that flow from biological differences. See id. at 83-94 (O'Connor, J., dissenting) (arguing that majority's reasoning regarding the likelihood of mother and father to develop relationship with child because of presence at birth rested on "overbroad sex-based generalization"); cf. Katherine M. Franke, The Central Mistake of Sex Discrimination Law: The Disaggregation of Sex from Gender, 144 U. Pa. L. Rev. 1, 98 (1995) (arguing that "biology is both a wrong and dangerous place to ground antidiscrimination law because it fails to account for the manner in which every sexual biological fact is meaningful only within a gendered frame of reference").

195. Again, a sex-discrimination win in the marriage context may not necessarily carry over for a range of reasons, including that deference to private employers' decisionmaking vis-à-vis their workplaces arguably plays a significant role in the grooming cases. See supra note 143 (discussing cases in which workplace grooming- and dress-code policies were upheld or struck down); cf. Greene, What Not to Wear, supra note 171, at 351 (discussing deference courts give to employers concerning grooming- and dress-code policies).

196. See United States v. Windsor, 133 S. Ct. 2675, 2696 (2013) (Roberts, C.J., dissenting) (disagreeing with the majority opinion, but arguing that scope of the holding 
had invalidated DOMA on a sex-discrimination theory, or on a theory that sexual-orientation discrimination warrants heightened scrutiny under the Equal Protection Clause, it would be harder for states to distinguish and protect their exclusionary marriage laws against invalidation. ${ }^{197}$

Yet, in the wake of a post-Windsor flood of rulings striking down state bans on same-sex couples' marriages, the broad reach of Windsor's doctrine, which might have been cabined as just described, became apparent. Dozens of courts, in all parts of the country, with both liberal and conservative judges, had little difficulty finding that marriage exclusions violated gay couples' constitutional rights. ${ }^{198}$

was narrow and did not determine whether states "may continue to utilize the traditional definition of marriage”). But see Bishop v. United States ex rel. Holder, 962 F. Supp. 2d 1252, 1296 (N.D. Okla. 2014) ("Supreme Court law now prohibits states from passing laws that are born of animosity against homosexuals ... There is no precise legal label for what has occurred . . beginning with Romer in 1996 and culminating in Windsor in 2013, but this Court knows a rhetorical shift when it sees one.”); Kitchen v. Herbert, 961 F. Supp. 2d 1181, 1194 (D. Utah 2013) ("The court agrees with Justice Scalia's interpretation of Windsor and finds that the important federalism concerns at issue here are nevertheless insufficient to save a state-law prohibition that denies the Plaintiffs their rights to due process and equal protection under the law.”), aff'd, 755 F.3d 1193 (10th Cir. 2014), cert. denied, No. 14-124, 2014 WL 3841263 (U.S. Oct. 6, 2014).

197. Illustrating this point is Nevada's decision to stop defending the state's exclusion of same-sex couples from marriage following a Ninth Circuit ruling that sexualorientation discrimination warrants heightened scrutiny. See Smithkline Beecham Corp. v. Abbott Labs., 740 F.3d 471, 481 (9th Cir. 2014) ("Windsor established a level of scrutiny for classifications based on sexual orientation that is unquestionably higher than rational basis review. In other words, Windsor requires that heightened scrutiny be applied to equal protection claims involving sexual orientation.”). After defending Nevada's marriage exclusion in a different case before the district court, the state's Republican governor commented, in light of the Ninth Circuit's heightened-scrutiny ruling, that "[i]t has become clear that this case is no longer defensible in court." Gay Marriage Ban Support Slips in Nevada, N.Y. Times (Feb. 10, 2014), http://www.nytimes.com/2014/02/11/us/ gay-marriage-ban-support-slips-in-nevada.html (on file with the Columbia Law Review).

198. See, e.g., Baskin v. Bogan, 766 F.3d 648, 672 (7th Cir.) (striking down state restrictions on same-sex couples' marriages), cert. denied, No. 14-277, 2014 WL 4425162 (U.S. Oct. 6, 2014); Bostic v. Schaefer, 760 F.3d 352, 384 (4th Cir.) (same), cert. denied, No. 14-225, 2014 WL 4230092 (U.S. Oct. 6, 2014); Bishop v. Smith, 760 F.3d 1070, 1074 (10th Cir. 2014) (same); Kitchen v. Herbert, 755 F.3d 1193, 1229-30 (10th Cir. 2014) (same); Love v. Beshear, 989 F. Supp. 2d 536, 550 (W.D. Ky. 2014) (same); Whitewood v. Wolf, 992 F. Supp. 2d 410, 431 (M.D. Pa. 2014) (same); Geiger v. Kitzhaber, 994 F. Supp. 2d 1128, 1146-48 (D. Or. 2014) (same); Latta v. Otter, No. 1:13-cv-00482-CWD, 2014 WL 1909999, at *28-*29 (D. Idaho May 13) (same), aff'd, No. 14-35420, 2014 WL 4977682 (9th Cir. Oct. 7, 2014); Henry v. Himes, No. 1:14-cv-129, 2014 WL 1418395, at *18 (S.D. Ohio Apr. 14, 2014) (same); DeBoer v. Snyder, 973 F. Supp. 2d 757, 775 (E.D. Mich.) (same), rev'd, No. 14-1341, 2014 WL 5748990 (6th Cir. Nov. 6, 2014), available at http:// sblog.s3.amazonaws.com/wp-content/uploads/2014/11/6th-CA-marriage-ruling-11-6-14. pdf (on file with the Columbia Law Review); De Leon v. Perry, 975 F. Supp. 2d 632, 666 (W.D. Tex. 2014) (same); Lee v. Orr, No. 13-cv-8719, 2014 WL 683680, at*1-*2 (N.D. Ill. Feb. 21, 2014) (same); Obergefell v. Wymyslo, 962 F. Supp. 2d 968, 997-98 (S.D. Ohio 2013) (same), rev'd sub nom. DeBoer, 2014 WL 5748990; Griego v. Oliver, 316 P.3d 865, 889 (N.M. 2013) (same); see also Tanco v. Haslam, No. 3:13-CV-01159, 2014 WL 997525, at *9 (M.D. Tenn. Mar. 14, 2014), rev'd sub nom. DeBoer, 2014 WL 5748990 (issuing 
This was the case notwithstanding Chief Justice Roberts's effort, in dissent, to highlight an additional doctrinal path by which lower courts could distinguish Windsor in future state-law challenges. While Roberts urged that states' freedom to block gay couples from marrying should remain unaffected by the majority's rebuke of the federal DOMA, ${ }^{199}$ not a single court in the first year after Windsor was decided took him up on that invitation. ${ }^{200}$

A similar phenomenon occurred following the Court's rulings in Romer and Lawrence. After each of those decisions, the willingness of lower courts to invalidate antigay laws increased exponentially even though Romer turned on a discrimination-of-an-unusual-character theory, and Lawrence focused its holding on the states' violation of gay people's liberty interests in their intimate relationships. ${ }^{201}$ To be sure, had the Court decided either case on a sex-discrimination theory, or even a sexual-orientation-discrimination theory, the numerous courts that distinguished Romer and Lawrence when rejecting marriage-equality claims would have had a more difficult time doing so. ${ }^{202}$ Yet, although the Court

preliminary injunction enjoining enforcement of Tennessee marriage-recognition ban). For a complete list of decisions in marriage cases post-Windsor, see Marriage Litigation, Freedom to Marry, http://www.freedomtomarry.org/litigation (on file with the Columbia Law Review) (last visited Oct. 13, 2014).

199. Windsor, 133 S. Ct. at 2697 (Roberts, C.J., dissenting).

200. Justice Scalia arguably predicted this result, writing, in dissent, that " $[\mathrm{b}] \mathrm{y}$ formally declaring anyone opposed to same-sex marriage an enemy of human decency, the majority arms well every challenger to a state law restricting marriage to its traditional definition." Id. at 2710 (Scalia, J., dissenting).

201. See, e.g., Log Cabin Republicans v. United States, 716 F. Supp. 2d 884, 929 (C.D. Cal. 2010) (striking down "Don't Ask, Don't Tell”), vacated as moot, 658 F.3d 1162 (9th Cir. 2011); Citizens for Equal Prot., Inc. v. Bruning, 368 F. Supp. 2d 980, 1002, 1004 (D. Neb. 2005) (citing Romer while striking down a Nebraska constitutional amendment denying recognition of same-sex civil unions, domestic partnerships, and similar same-sex relationships), rev'd sub nom. Citizens for Equal Prot. v. Bruning, 455 F.3d 859 (8th Cir. 2006); Jegley v. Picado, 80 S.W.3d 332, 353-54 (Ark. 2002) (striking down Arkansas sodomy statute because it served no rational purpose and violated Arkansas's equalprotection guarantee); Fla. Dep't of Children \& Families v. Adoption of X.X.G., 45 So. 3d 79, 91-92 (Fla. Dist. Ct. App. 2010) (holding that Florida's categorical exclusion of gay people from adopting served no rational purpose and violated Florida's equal-protection guarantee); State v. Limon, 122 P.3d 22, 40-41 (Kan. 2005) (concluding Kansas's "Romeo and Juliet" law violated the Equal Protection Clause by imposing different penalties for consensual sexual acts between same- and different-sex couples); Goodridge v. Dep't of Pub. Health, 798 N.E.2d 941, 948, 962, 969 (Mass. 2003) (citing both Romer and Lawrence to conclude that "barring an individual from the protections, benefits, and obligations of civil marriage solely because that person would marry a person of the same sex violates the Massachusetts Constitution").

202. See, e.g., Jackson v. Abercrombie, 884 F. Supp. 2d 1065, 1092 (D. Haw. 2012) ("In contrast to Amendment 2 in Romer, Hawaii's marriage laws are not so unusual or unduly broad that they are 'inexplicable by anything but animus' towards same-sex couples." (citation omitted)), vacated as moot, No. 12-16995, 2014 WL 5088199 (9th Cir. Oct. 10, 2014); Wilson v. Ake, 354 F. Supp. 2d 1298, 1306-08 (M.D. Fla. 2005) (concluding that the "Supreme Court's decision in Lawrence cannot be interpreted as creating a fundamental right to same-sex marriage" or as requiring heightened scrutiny for sexual- 
expressly sidestepped the marriage question in Lawrence ${ }^{203}$ and did not mention marriage at all in Romer, its decisions in those cases infused many lower-court rulings granting marriage-equality claims. ${ }^{204}$

\section{Theorizing the Power of Discrete Arguments in Social-Change Litigation}

It is not necessarily obvious why Windsor (or Lawrence and Romer) had such strong ripple effects given their arguably limited doctrinal holdings. The discrimination-of-an-unusual-character rationale is keyed to a challenged law's distinctiveness; by design, it will not necessarily carry far beyond the invalidated measure. ${ }^{205}$ Still, narrowly written

orientation discrimination (citation omitted)); In re Kandu, 315 B.R. 123, 140 (Bankr. W.D. Wash. 2004) (rejecting federal DOMA challenge and observing that "Lawrence holding does not require a change in the federal statutory approach to marriage"); Standhardt v. Superior Court, 77 P.3d 451, 465 (Ariz. Ct. App. 2003) (upholding Arizona's marriage laws and claiming that, unlike Colorado's ban on antidiscrimination protections for gay people, Arizona's laws "are not so exceptional and unduly broad as to render the State's reasons for their enactment 'inexplicable by anything but animus' towards Arizona's homosexual residents” (quoting Romer v. Evans, 517 U.S. 620, 632 (1996))); In re Marriage of J.B., 326 S.W.3d 654, 680 (Tex. App. 2010) (citing Romer Court's focus on animus and concluding "Texas's laws governing marriage and divorce, by contrast, are rationally related to the legitimate state interest in fostering the best possible environment for procreation and child-raising" and "Romer and Lawrence are distinguishable and offer ... no support" for marriage-equality argument).

203. See Lawrence v. Texas, 539 U.S. 558, 578 (2003) (stating that the challenge to Texas's "homosexual conduct" law "does not involve whether the government must give formal recognition to any relationship that homosexual persons seek to enter"). Justice O'Connor took the same position in her equal-protection-focused concurrence. See id. at 585 (O'Connor, J., concurring) ("That this law as applied to private, consensual conduct is unconstitutional under the Equal Protection Clause does not mean that other laws distinguishing between heterosexuals and homosexuals would similarly fail under rational basis review.").

204. See, e.g., Perry v. Brown, 671 F.3d 1052, 1092-93 (9th Cir. 2012) (citing Lawrence for the proposition that tradition was an insufficient basis for sustaining the exclusion of same-sex couples from marriage and citing Romer's rejection of animus toward the "class of persons affected" as support for invalidating Proposition 8's singular burden on gay people seeking to marry), vacated and remanded sub nom. Hollingsworth v. Perry, 133 S. Ct. 2652 (2013); Massachusetts v. U.S. Dep't of Health \& Human Servs., 682 F.3d 1, 15 (1st Cir. 2012) ("[S]peaking directly of same-sex preferences, Lawrence ruled that moral disapproval alone cannot justify legislation discriminating on this basis. Moral judgments can hardly be avoided in legislation, but Lawrence and Romer have undercut this basis." (citations omitted)), cert. denied, 133 S. Ct. 2887 (2013); Windsor v. United States, 833 F. Supp. 2d 394, 402 (S.D.N.Y. 2012) (citing Lawrence and Romer to distinguish between laws requiring rational-basis analysis and "law[s that] exhibit[] . . a desire to harm a politically unpopular group,' which receive 'a more searching form of rational basis review... under the Equal Protection Clause'” (alterations in original) (quoting Lawrence, 539 U.S at 580 (O'Connor, J., concurring))), aff'd, 699 F.3d 169 (2d Cir. 2012), aff'd, 133 S. Ct. 2675 (2013).

205. In City of Cleburne v. Cleburne Living Center, Inc., for example, the Court rejected a zoning ordinance that burdened people with intellectual disabilities because fear and "mere negative attitudes" were not legitimate bases for government action. 473 U.S. 432, 448 (1985). But this analysis did not lead the Court to reject a law that imposed relatively burdensome involuntary civil commitment rules on people with intellectual disabilities, 
opinions have the potential for relatively high impact for two reasons I explore here, again using the marriage cases, along with others, to illustrate.

1. Building on Preexisting Norm Destabilization. — First, a ruling that strikes down a legislative or initiated measure for being a discrimination of an unusual character itself reflects-and capitalizes on-preexisting changes to hostile social norms regarding the relevant community. A court can conclude that a law's negative treatment of a social group is both unusual and impermissible only after the challenged discrimination is no longer widely seen as part of the natural order; until that time, the argument that the law is either unusual or discriminatory will have little plausibility. In other words, if it were still an accepted social practice to discriminate against that group, the law at issue would not be so troubling.

The Court's notorious 1986 ruling in Bowers v. Hardwick helps illustrate the point. ${ }^{206}$ There, while upholding Georgia's sodomy law against a challenge by a gay man arrested in his own bedroom for engaging in consensual oral sex, the Court deemed the man's privacy claim as "at best, facetious." ${ }^{207}$ Neither Fourteenth Amendment jurisprudence nor much of the surrounding society had reached the point where discrimination against gay people could easily be condemned for its unusual character. ${ }^{208}$ This made it particularly striking when the Court in

notwithstanding arguments that similar impermissible motives were present. See Heller v. Doe ex rel. Doe, 509 U.S. 312, 321 (1993) (finding "more than adequate justifications for the differences in treatment between the mentally retarded and the mentally ill"); id. at 348 (Souter, J., dissenting) ("Kentucky is being allowed to draw a distinction that is difficult to see as resting on anything other than the stereotypical assumption that the retarded are 'perpetual children,' an assumption that has historically been taken to justify the disrespect and 'grotesque mistreatment' to which the retarded have been subjected.").

206. 478 U.S. 186 (1986).

207. Id. at 194.

208. On the damaging ripple effects of Bowers $v$. Hardwick, both legally and socially, see, e.g., Mary C. Dunlap, Gay Men and Lesbians Down by Law in the 1990's USA: The Continuing Toll of Bowers v. Hardwick, 24 Golden Gate U. L. Rev. 1 (1994).

The Court arguably misjudged popular sentiment in Bowers, at least with respect to the legitimacy of sodomy laws. The ruling provoked widespread opposition and nearly universal condemnation by legal academics. See, e.g., Anne B. Goldstein, History, Homosexuality, and Political Values: Searching for the Hidden Determinants of Bowers $v$. Hardwick, 97 Yale L.J. 1073, 1087 (1988) (describing "majority's use of the concept of homosexuality" as "flawed"); Jed Rubenfeld, The Right of Privacy, 102 Harv. L. Rev. 737, 739 (1989) (asserting that "Hardwick has exposed deep flaws in the prevailing jurisprudence and ideology of privacy"); Thomas B. Stoddard, Bowers v. Hardwick: Precedent by Personal Predilection, 54 U. Chi. L. Rev. 648, 656 (1987) ("Bowers v. Hardwick is, fundamentally, lawmaking by personal predilection-precisely the sort of judicial self-indulgence that the critics of the Warren Court most often decry. It is a cavalier decision, without reference to either standard or principle and in blatant disregard of well-settled procedural rules."); Joseph Robert Thornton, Bowers v. Hardwick: An Incomplete Constitutional Analysis, 65 N.C. L. Rev. 1100, 1122 (1987) ("[T]he [Bowers] opinion reads as if the majority made up its mind to deny homosexuals 
Lawrence declared that "Bowers was not correct when it was decided, and it is not correct today." 209

In fact, it took a decade for the norm of antigay discrimination to become sufficiently destabilized so that a majority of the Court could find flaws in a ban on discrimination protections for gay people that it could not see in Georgia's arrest of Mr. Hardwick. ${ }^{210}$ Rejecting Justice Scalia's insistence in dissent that the Court had taken sides in a kulturkampf, ${ }^{211}$ the Romer majority deemed "implausible" the state's claim that the amendment permissibly denied only "special rights." 212 The Court (twothirds of the Court, really) could see, moreover, that the discrimination at issue was of an unusual character and that the amendment's targeting of gay people was "not within our constitutional tradition."213

This response to surrounding social change can be seen in the Windsor ruling as well; seventeen years after Romer, the same discrimination-of-an-unusual-character argument was now plausible in the marriage context. If it were still the norm for governments to discriminate openly against gay people, the Court in Windsor would not have been so troubled by the federal government's decision to reject a subset of marriages that states had chosen to sanctify. ${ }^{214}$ The Court's

constitutional protection, then applied whatever law and tradition supported its position and ignored all authority and arguments to the contrary."); Timothy W. Reinig, Comment, Sin, Stigma \& Society: A Critique of Morality and Values in Democratic Law and Policy, 38 Buff. L. Rev. 859, 862 (1990) ("Prejudice, rather than sound legal argument, seems to be the basis for the result in Hardwick.”).

209. Lawrence, 539 U.S. at 578.

210. See Romer v. Evans, 517 U.S. 620 (1996). In the preceding term, the Court ruled unanimously against an organization of gay Irish individuals that wanted to participate in Boston's Saint Patrick's parade, but its decision was a notable prelude to Romer because of the shift in tone. Hurley v. Irish-Am. Gay, Lesbian \& Bisexual Grp. of Boston, 515 U.S. 557, 581 (1995). While the gay litigants lost, the Court's opinion did not emanate the discomfort or hostility that characterized the Bowers decision or even the mildly written "gay Olympics" decision that came a year after Bowers. Id. ("Our holding today rests not on any particular view about the Council's message but on the Nation's commitment to protect freedom of speech.”); see also S.F. Arts \& Athletics, Inc. v. U.S. Olympic Comm., 483 U.S. 522, 542 (1987) (upholding the U.S. Olympic Committee's objection to the use of "Olympics" associated with sporting events featuring gay athletes notwithstanding widespread use of "Olympics" by other competitions).

211. Romer, 517 U.S. at 636 (Scalia, J., dissenting).

212. Id. at 626 .

213. Id. at 633 (citation omitted). The Court quite deliberately tied its analysis to broader American traditions by beginning its opinion with Justice Harlan's century-old Plessy dissent for the proposition that the law must be "neutral[] where the rights of persons are at stake." Id. at 623.

214. Presumably, this foundation of social change, including the years of effort to lay the groundwork for these changes, see, e.g., Mary Bonauto \& James Esseks, Marriage Equality Advocacy from the Trenches, 29 Colum. J. Gender \& L. (forthcoming 2015) (describing early years of marriage-equality advocacy), helps explain why the backlash that some anticipated in response to marriage litigation has not materialized in a significant way. Cf. Michael J. Klarman, From the Closet to the Altar: Courts, Backlash, and the 
concern about DOMA's demeaning of same-sex couples and their children $^{215}$ likewise would not have made sense in a jurisprudential-or social-world in which disfavoring gay people was widely permitted. ${ }^{216}$ Indeed, the Court's opinion expressly acknowledged these external changes in a range of ways, including in characterizing New York's decision to recognize same-sex couples' marriages as an effort "to eliminate inequality." ${ }^{117}$ In this way, and by invoking states' commitment to equality, the Court framed its analysis as continuing, rather than breaking with, tradition. ${ }^{218}$

In this sense, an incremental argument such as "discrimination of an unusual character" does not ask the court to break new conceptual ground like a risky argument might. Instead, it deliberately asks the court to apply a well-settled analysis-to find that "[i]t is not within our constitutional tradition to enact laws of this sort," as the Court wrote in Romer. ${ }^{219}$ Put simply, the context may be new but the concept is not.

2. Solidifying and Amplifying Preexisting Changes in Public Discourse and Related Jurisprudence. - Second, even assuming the narrowly written rulings focused on here reflect preexisting changes, as just described, judicial ratification almost certainly also solidifies and amplifies those changes both in public discourse and in later cases. ${ }^{220}$

Struggle for Same-Sex Marriage 166-69 (2013) (discussing history of backlash against marriage litigation).

215. The Court in Windsor observed that the federal government's disregard of samesex couples' marriages "humiliates tens of thousands of children now being raised by same-sex couples. The law in question makes it even more difficult for the children to understand the integrity and closeness of their own family and its concord with other families in their community and in their daily lives." United States v. Windsor, $133 \mathrm{~S}$. Ct. 2675, 2694 (2013).

216. See, e.g., Barry Friedman, Mediated Popular Constitutionalism, 101 Mich. L. Rev. 2596, 2606 (2003) ("[J] udicial decisions rest within a range of acceptability to a majority of the people.”); see also Steven G. Calabresi, Thayer's Clear Mistake, 88 Nw. U. L. Rev. 269, 272 (1993) ("Mr. Dooley's dictum about the Supreme Court's tendency to follow the election returns seems no less apt today than when it was first printed almost a century ago."). Fittingly, given the theory advanced here, the U.S. Supreme Court did not even issue an opinion to accompany its first-ever invalidation of an antigay act in 1958. See One, Inc. v. Olesen, 355 U.S. 371, 371 (1958) (per curiam), rev'g 241 F.2d 772 (9th Cir. 1957). Instead, the Court, per curiam, summarily reversed the Ninth Circuit's determination that a gay-oriented magazine could be deemed "nonmailable" by the postmaster of Los Angeles because of its content. Id. An opinion would have required the Court to explain why articles written about gay people were not necessarily obscene under federal law, a difficult task in the 1950s.

217. Windsor, 133 S. Ct. at 2694.

218. The same can be said of the Court's choice to tie DOMA's violation of antitargeting principles not only to the measure invalidated in Romer but also to the fortyyear-old ruling in Department of Agriculture $v$. Moreno rejecting a law that had no purpose other than to harm its unpopular targets. Id. at 2693 (citing U.S. Dep't of Agric. v. Moreno, 413 U.S. 528, 534-35 (1973)).

219. Romer v. Evans, 517 U.S. 620, 633 (1996).

220. See also Post, Fashioning the Legal Constitution, supra note 1, at 8 ("[C] onstitu- 
Turning to public discourse first, it should not be a controversial proposition that high-visibility coverage has put legal decisions in a position to influence public discussion of marriage and related issues. ${ }^{221}$ The very nature of legal rulings also enhances their power; while elected officials and prominent political and cultural leaders have an impact on popular discourse through their statements and conduct, judges actually decide questions and, as such, are distinctly authoritative. ${ }^{222}$ Their decisions have real-world consequences, at least when they are final, and thus necessarily become a touchstone for future public debate.

Moreover, because case outcomes become known to the public through media headlines and sound-bite coverage, decisions' rationales-including the choice of a narrow theory over a norm-challenging one-tend to have little public exposure or impact relative to the final judgment. As Paul Gewirtz once observed in a different context, "[I]t is possible that the manner in which a court justifies a particular remedy will make no dignitary difference at all. We who live by the lamp may exaggerate the importance of words." ${ }^{223}$

Still, judges surely pay attention to their colleagues' opinions, so the relatively unnuanced public depiction of the Supreme Court's ruling in Windsor, for example, cannot alone explain why so many lower courts relied on Windsor to strike state marriage bans. That coverage, however, along with news about the growing number of states that recognized marriage equality legislatively while Windsor was pending, ${ }^{224}$ presumably

tional law both arises from and in turn regulates culture.").

221. For discussions of the impact of court rulings on public discourse generally, see, e.g., Patrick J. Egan et al., Gay Rights, in Public Opinion and Constitutional Controversy 234, 239-45 (Nathaniel Persily et al. eds., 2008) (examining evidence suggesting Supreme Court's agenda-setting role affects public opinion, rather than vice versa). But see Stephen B. Burbank, Alternative Career Resolution II: Changing the Tenure of Supreme Court Justices, 154 U. Pa. L. Rev. 1511, 1527-28 (2006) (describing limited public attention given to judicial opinions). For analysis of the extensive media coverage of marriage cases, see generally Nathaniel Persily, Gay Marriage, Public Opinion, and the Courts (Penn Law Legal Scholarship Repository, Faculty Scholarship, Paper No. 91, 2006), available at http://scholarship.law.upenn.edu/faculty_scholarship/91 (on file with the Columbia Law Review).

222. Arguably, a judicially sanctioned outcome has a unique type of legitimacy because it "bear[s] witness that it was reached through the discipline of the pattern of the law." Edward H. Levi, The Nature of Judicial Reasoning, 32 U. Chi. L. Rev. 395, 409 (1965).

223. Paul Gewirtz, Remedies and Resistance, 92 Yale L.J. 585, 669 (1983); cf. Vicki C. Jackson, Constitutions as "Living Trees"? Comparative Constitutional Law and Interpretive Metaphors, 75 Fordham L. Rev. 921, 940 n.78 (2006) ("Although the literature suggests low public attention to the reasoning of most judicial opinions, mass media on occasion devotes time to legal reasoning in ways that may affect general impressions of the legitimacy of the courts' work." (citations omitted)).

224. See, e.g., Adam Liptak, Supreme Court Weighs Cases Redefining Legal Equality, N.Y. Times (June 22, 2013), http://www.nytimes.com/2013/06/23/us/supreme-courtweighs-cases-redefining-legal-equality.html (on file with the Columbia Law Review) ("In the three months since... [the Windsor] argument, three more states have adopted same-sex 
prompted further shifts in public opinion. ${ }^{225}$ And these shifts, in turn, shaped the landscape in which courts were hearing marriage-equality cases after the Windsor term ended.

Emblematic were statements from national media, such as TIME, which declared that "gay marriage" had already won. ${ }^{226}$ To stand against what appeared to be a sweeping wave of change, while not unimaginable, would now pose its own risks to judicial legitimacy. ${ }^{227}$ After the first courts

marriage, raising the total to 12, along with the District of Columbia."); Dorothy J. Samuels, And Then There Were Ten, N.Y. Times: Taking Note (Apr. 26, 2013, 10:28 AM), http://takingnote.blogs.nytimes.com/2013/04/26/and-then-there-were-ten/ (on file with the Columbia Law Review) ("Rhode Island's advance adds to the building sense of momentum for marriage equality.”).

225. See, e.g., Jon Cohen, Gay Marriage Support Hits New High in Post-ABC Poll, Wash. Post: The Fix (Mar. 18, 2013), http://www.washingtonpost.com/blogs/thefix/wp/2013/03/18/gay-marriage-support-hits-new-high-in-post-abc-poll (on file with the Columbia Law Review) (observing recent increase in percentage of Americans who support marriage equality); Micah Cohen, Poll Finds Record Support for Same-Sex Marriage in California, N.Y. Times: FiveThirtyEight (Mar. 1, 2013, 4:43 PM), http://fivethirtyeight. blogs.nytimes.com/2013/03/01/poll-finds-record-support-for-same-sex-marriage-in-califor nia (on file with the Columbia Law Review) (discussing dramatic increase in support for marriage equality in California since 2008 approval of Proposition 8).

226. TIME had this message on its cover even before Windsor was decided. TIME (Apr. 8, 2013), available at http://content.time.com/time/covers/0,16641,20130408,00. html (on file with the Columbia Law Review). Even conservative talk-show host Rush Limbaugh conceded that marriage equality was inevitable and that opponents had lost on the issue. Aaron Blake, Rush Limbaugh: Gay Marriage 'Inevitable,' Conservatives 'Lost,' Wash. Post (Mar. 28, 2013), http://www.washingtonpost.com/blogs/post-politics/wp/ 2013/03/28/rush-limbaugh-gay-marriage-inevitable-conservatives-lost (on file with the Columbia Law Review).

LGBT advocacy groups made efforts to limit the sense of marriage-equality efforts being completed given that most states, even a year after Windsor, continued to exclude same-sex couples from marriage. See, e.g., Press Release, Freedom to Marry, One Year After Windsor Ruling: Momentum for the Freedom to Marry Reaches Record Highs (June 25, 2014), http://www.freedomtomarry.org/press/press-release/one-year-after-historicwindsor-ruling-momentum-for-the-freedom-to-marry (on file with the Columbia Law Review) ("Same-sex couples are still denied the freedom to marry in 31 states where 56 percent of the country resides. Yet twenty federal and state judges have ruled this discrimination unconstitutional in whole or in part in the past year. The inequity is stark.").

227. See Robert A. Dahl, Democracy and Its Critics 190 (1989) ("[T] he views of a majority of the justices of the Supreme Court are never out of line for very long with the views prevailing among the lawmaking majorities of the country."); Robert G. McCloskey, The American Supreme Court 260 (Daniel J. Boorstin ed., 5th ed. 2010) ("[I]t is hard to find a single historical instance when the Court has stood firm for very long against a really clear wave of public demand.”); Richard H. Fallon, Jr., Legitimacy and the Constitution, 118 Harv. L. Rev. 1787, 1833 (2005) ("Justices who defy aroused public opinion . . know that they risk[] provoking a political backlash that ultimately could cause their doctrinal handiwork to collapse. Possibly as a result of the Court's concern for its own sociological legitimacy, it has seldom remained dramatically at odds with aroused public opinion . . .." (footnote omitted)); Friedman, supra note 220, at 2611-13 (underscoring "[j]udges do not live in a cocoon" and "face [an incentive] to remain within the range of public opinion"). 
to rule in Windsor's wake ruled in favor of marriage equality, the risks arguably became even greater, particularly as the rulings were lauded at the highest levels of government, ${ }^{228}$ elicited bipartisan support, ${ }^{229}$ and came in states not thought to be especially friendly to gay-rights claims of this sort. ${ }^{230}$

In this way, Windsor's discrimination-of-an-unusual-character analysis was not only solidified but also amplified-with hydraulic effects-by both the media and lower courts.

\section{Retaining a Role for Risky Arguments}

Risky arguments might seem to be almost irrelevant given that incremental legal theories can both gain traction and elide the downsides of their norm-challenging counterparts. But this conclusion would miss two significant roles that risky arguments likely play in decisionmaking.

First, as discussed earlier, risky arguments might have a particular ability to illuminate defects in a challenged law precisely because they focus attention on problematic underlying norms. In the marriage cases, for example, the sex-discrimination argument seems to present the clearest frame from which to challenge governments' proffered justification that children need male-female couples as parents because of the differences between mothers and fathers. ${ }^{231}$

228. Press Release, Office of the Press Sec'y, White House, Remarks by the President at Pride Month Celebration (June 30, 2014), http://www.whitehouse.gov/the-press-office/ 2014/06/30/remarks-president-pride-month-celebration (on file with the Columbia Law Review) ("Same-sex marriage has gone into effect in 10 more states-(applause)—which means that 43 percent of Americans now live in states where you're free to marry who you love.").

229. See Erik Eckholm, Republicans from the West Give Support for Gay Marriage, N.Y. Times (Mar. 3, 2014), http://www.nytimes.com/2014/03/04/us/republicans-fromwest-give-support-for-gay-marriage.html (on file with the Columbia Law Review) ("Evoking Ronald Reagan and Barry Goldwater, a group of Western-state Republicans plans to enter the battle in favor of same-sex marriage on Tuesday, urging a federal appeals court to declare gay marriage bans in Utah and Oklahoma unconstitutional.”).

230. See, e.g., De Leon v. Perry, 975 F. Supp. 2d 632, 662 (W.D. Tex. 2014) (holding Texas's marriage bans violate plaintiffs' due-process rights); Bostic v. Rainey, 970 F. Supp. 2d 456, 484 (E.D. Va.) (striking down Virginia's marriage bans for violating plaintiffs' dueprocess and equal-protection rights), aff'd sub nom. Bostic v. Schaefer, 760 F.3d 352 (4th Cir.), cert. denied, No. 14-225, 2014 WL 4230092 (U.S. Oct. 6, 2014); Kitchen v. Herbert, 961 F. Supp. 2d 1181, 1216 (D. Utah 2013) (striking down Utah's marriage bans for violating plaintiffs' due-process and equal-protection rights), aff'd, 755 F.3d 1193 (10th Cir.), cert. denied, No. 14-124, 2014 WL 3841263 (U.S. Oct. 6, 2014). Notably, some of the early post-Windsor cases also presented highly compelling facts, including one couple who took an air-ambulance flight to another state so they could be married shortly before one member of the couple died. See Obergefell v. Wymyslo, 962 F. Supp. 2d 968, 976 (S.D. Ohio 2013), rev'd sub nom. DeBoer v. Snyder, No. 14-1341, 2014 WL 5748990 (6th Cir. Nov. 6, 2014), available at http://sblog.s3.amazonaws.com/wp-content/uploads/2014/ 11/6th-CA-marriage-ruling-11-6-14.pdf (on file with the Columbia Law Review).

231. See Case, What Feminists Have to Lose, supra note 32, at 1225 (calling the 
Second, legal claims and theories have an expressive function within litigation in addition to providing a doctrinal path toward a desired outcome. ${ }^{232}$ While the expressive function of factual allegations in complaints has received some attention, ${ }^{233}$ and the expressive function of legal theory much more, ${ }^{234}$ this role of legal theory within litigation warrants consideration as well.

More specifically, like any other type of case, social-change cases typically can be argued based on a range of theories, and advocates must be strategic about which theories to advance, in what order, and at what length. But even with those questions decided, the individual arguments do not operate in standalone fashion. Instead, they have their own ecology, each affecting the reception of the others and all together creating synergies arising from their unique contributions. ${ }^{235}$

hypothetical rationale offered by legislatures that children are better off being raised by a mother and a father than by same-sex partners "deeply disturbing"); Widiss et al., supra note 32, at 490 ("[C] ourts in the marriage cases have fallen back on an essentialized understanding of gender roles to hold that legislatures may assume that children do best with a 'mother' and a 'father' and that male and female parents, simply by virtue of their sex, play significantly different roles for their children.”).

232. Some have compared the expressive role of legal theory to its determinative role, observing that theory "cannot tell us what to value, but it can help us (judges, scholars, citizens) make choices by helping us to articulate what we value." Joseph William Singer, The Player and the Cards: Nihilism and Legal Theory, 94 Yale L.J. 1, 63 (1984). Others have focused on the expressive function of law as it relates to human behavior. See, e.g., Eric A. Posner, Law and Social Norms 1-2 (2000) (cataloguing diverse ways in which legal intervention can influence or change social norms); Cass R. Sunstein, On the Expressive Function of Law, 144 U. Pa. L. Rev. 2021, 2025-29 (1996) ("[M]y principal aim is to defend laws that attempt to alter norms, rather than laws that merely 'speak.'”). Still others have addressed the expressive function of litigation itself.

Consolidating many of these ideas, Paul Stephan wrote:

As a matter of legal theory, there exist many ways to capture the expressive function of litigation. Those of us who work in law and economics might say that litigation generates public goods in the form of more and better information about the scope and meaning of legal rules. Those interested in theories of justice might say that litigation engages society in reasoned deliberation that allows society to better articulate its sense of moral value. Those with a post-modern inclination might argue that litigation serves as a kind of performance through which social meaning is constructed. A common thread underlies each of these otherwise disparate conceptions: litigation has purposes and functions that are independent of the parties before the court. Judges and lawyers engaged in litigation represent society, whether self-consciously or not, and society in turn shapes and places its demands on those actors.

Paul Stephan, A Becoming Modesty-U.S. Litigation in the Mirror of International Law, 52 DePaul L. Rev. 627, 644-45 (2002) (footnotes omitted).

233. See, e.g., Eastman, supra note 39 , at 766 (describing how moral outrage is often lost in facts of civil-rights complaints).

234. See supra note 232 (discussing expressive role of legal theory relative to theory's determinative role).

235. A basic principle of ecology stresses the interconnections and synergies among parts of the same system. See Fritjof Capra, The Web of Life: A New Scientific 
While risky arguments have a norm-confronting style that may make them less likely to be embraced by a court, their clarity about underlying problems might help generate or affirm a decisionmaker's sense that something is troubling about the measure at issue. Then, if the decisionmaker is not prepared, either intellectually or as a matter of practice, to engage with the problem on those terms, other, more discrete arguments might gain in appeal because they are easier to grasp or seem less broadly impactful, or both.

In other words, in the ecology of social-change litigation, risky and discrete arguments may interact synergistically, with the risky argument destabilizing the challenged law and the discrete argument offering an easier path to decision. This is not unlike the process that occurred in the early marriage cases, where several courts brought themselves to the point of recognizing the constitutional flaws embedded in states' exclusion of same-sex couples from marriage, but were reluctant to follow that conclusion through by requiring marriage access as a remedy. In Vermont, for example, the state supreme court found that the state had violated same-sex couples' rights under the state constitution's Common Benefits Clause, but it allowed the legislature to grant civil unions as a remedy. ${ }^{236}$ Several years later, the New Jersey Supreme Court did essentially the same thing, finding that exclusion from marriage violated samesex couples' equality rights, but allowing the state legislature to provide civil unions as a remedy. ${ }^{237}$

In these cases, the alternate remedy of civil unions arguably served a function analogous to that of the discrete discrimination-of-an-unusualcharacter theory in Windsor. It allowed for required change without committing the courts to a full-on engagement with the norms their decisions challenged. And, likewise, the decisions in Vermont and New Jersey ultimately paved the way for later determinations, either by the legislature or the court, to require marriage. ${ }^{238}$

These moves could be described as minimalist ${ }^{239}$ and also as consistent with William Eskridge's "jurisprudence of tolerance," through which courts-and in particular the Supreme Court-are committed to

Understanding of Living Systems 297-304 (1996) ("All members of an ecological community are interconnected in a vast and intricate network of relationships, the web of life. They derive their essential properties and, in fact, their very existence from their relationships to other things.").

236. Baker v. State, 744 A.2d 864, 888-89 (Vt. 1999).

237. Lewis v. Harris, 908 A.2d 196, 224 (N.J. 2006); see also 2006 N.J. Laws 975 ("It is the intent of the Legislature to comply with the constitutional mandate set forth by the New Jersey Supreme Court in the recent landmark decision of Lewis v. Harris . . .")

238. See 2009 Vt. Acts \& Resolves 33 ("The purpose of this act [creating civil unions] is to recognize legal equality in the civil marriage laws . ...”); Garden State Equal. v. Dow, 82 A.3d 336, 367-68 (N.J. Super. Ct. 2013) ("The equality demanded by Lewis now requires that same-sex couples in New Jersey be allowed to marry.").

239. See supra note 27 and accompanying text (exploring Sunstein's theory of judicial minimalism). 
"lowering the stakes of identity politics" by issuing marriage rulings only to the extent the "country is [] willing to go along." 240

But without the claim for marriage-that full-on demand for social change-it is hard to imagine that civil unions would have been so easily embraced as a statewide mechanism for recognizing same-sex couples' relationships. Put simply, as is often the case in politics and at times in constitutional interpretation, the arguments at the margins help generate buy-in for arguments that appear to be more middle of the road. ${ }^{241}$

The remaining question here is a normative one: Who should take the risk of making risky arguments, given their synergistic contributions? In any given case, it might seem reasonable for the party litigating a case to make all arguments, from discrete to risky, to maximize the potential synergies among them. While page and attention limits are not endless, as noted earlier, a party that groups the arguments together can invoke their collective power, and then concentrate its resources on the theories most likely to succeed and leave it to amici to reinforce and develop the others.

On the other hand, risky arguments can sometimes trigger dormant opposition, as was also discussed at the outset. From this vantage point, it may be better for amici to advance arguments that set an outer bound and shape the context in which other claims are heard and have the party stay away from them altogether. That approach also minimizes the reputational consequences for the party to the extent an argument risks being seen as implausible. It also reduces the chance that a judge will reach out specifically to reject the argument even while issuing a favorable ruling.

It would be folly to make a strong recommendation of either strategy from the pages of a law-review essay, abstracted from the circumstances of a particular case. Instead, the takeaway point, for litigation as well as theory, is the inevitability of choice-and risk-and the absence of absolute answers.

240. William N. Eskridge, Lawrence's Jurisprudence of Tolerance: Judicial Review to Lower the Stakes of Identity Politics, 88 Minn. L. Rev. 1021, 1025-26 (2004). For commentary on and a critique of this theory as it relates to Lawrence, see Jamal Greene, Beyond Lawrence: Metaprivacy and Punishment, 115 Yale L.J. 1862, 1882-83 (2006) (arguing that Lawrence "does not source its emerging awareness within the gay rights movement" but rather "alters the criteria upon which putatively protected expressive conduct is to be formally judged").

241. For discussion of the ways in which the terrain of "acceptable" argument shifts by virtue of arguments made on both sides, see Siegel, Constitutional Culture, supra note 11, at 1330-32 (explaining, through the Equal Rights Amendment's history, "how American constitutional culture enables creative new claims about the Constitution's meaning" and how "proposed understandings ultimately assume a form in which they can be integrated into the tradition they challenge"); see also Siegel, Equality Talk, supra note 135, at 1476 (discussing shifts in meaning of Brown v. Board of Education resulting from changes in social-movement strategies supportive of and adverse to the decision). 


\section{CONCLUSION}

The presence of norm-challenging arguments in social-justice cases can call attention to deep problems that underlie a challenged law. In this way, the sex-discrimination argument arguably has contributed to decisionmakers' understanding of marriage bans' deficits, even when judicial opinions do not rely on it.

At the same time, rulings that rest on narrower arguments may also be capable of undermining troubling norms without some of the risks posed by arguments that directly and sometimes uncomfortably challenge settled views. Pro-marriage-equality rulings, for example, have narrowed the scope of permissible discrimination based on sex even without engaging the sex-discrimination argument.

Put more generally, norm-challenging arguments have valuable synergies with-and may lay the groundwork for-the more incremental arguments that most judges are inclined to adopt. In this light, rulings allowing marriage for same-sex couples can be understood to acknowledge that, contra Justice Bradley's opinion in Bradwell, society will survive even if the law is disempowered once more from enforcing sex roles. More generally, narrow victories in social-change cases may reinforce that the world will go on and thrive, even as the traditional, though unmentioned, underpinnings of discriminatory rules give way. 
